Prepared in cooperation with the lowa Department of Transportation and lowa Highway Research Board (Project HR-140)

\title{
Floods of July 23-26, 2010, in the Little Maquoketa River and Maquoketa River Basins, Northeast lowa
}

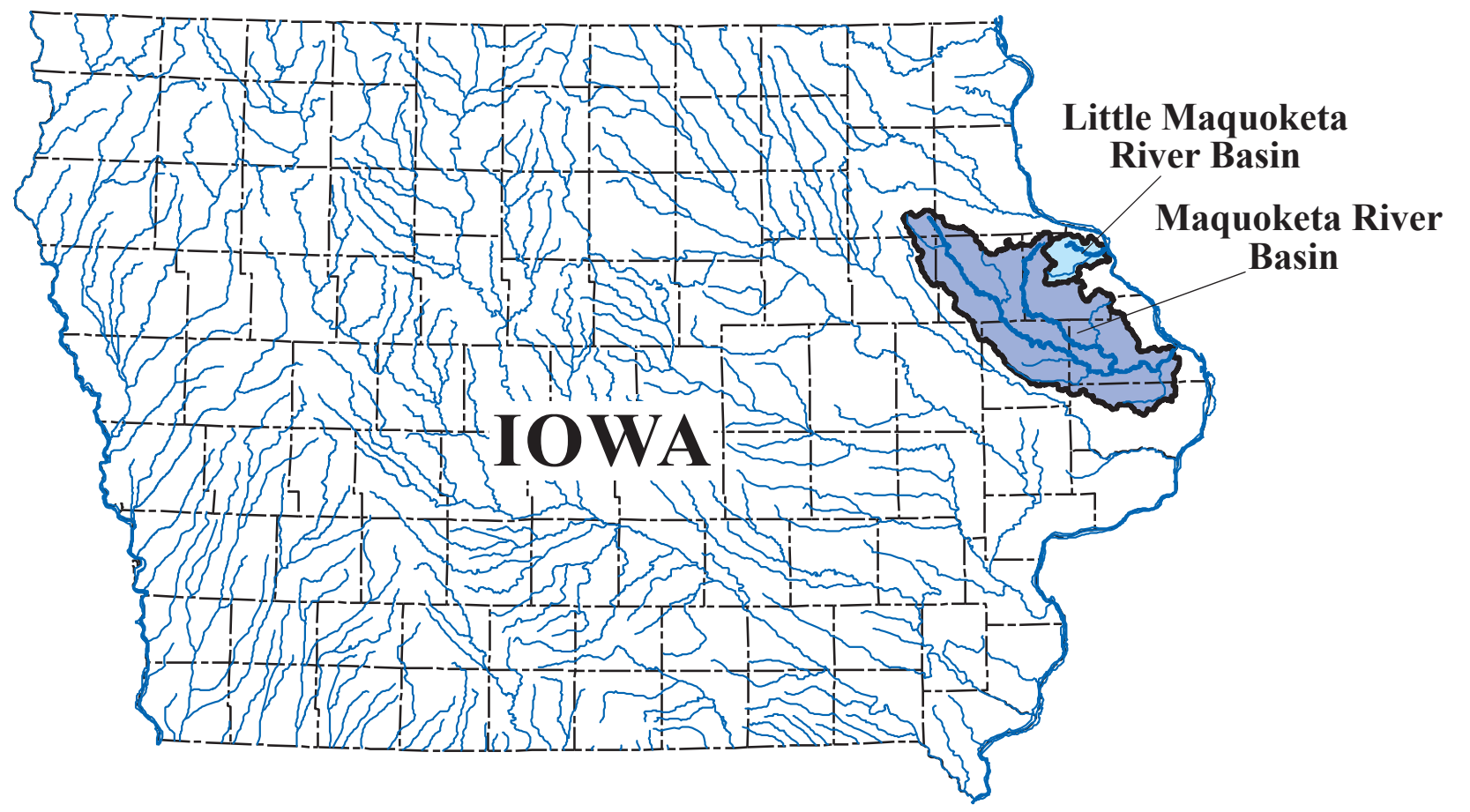

Open-File Report 2011-1301 
Cover. Map of lowa showing location of Little Maquoketa River and Maquoketa River Basins. 


\section{Floods of July 23-26, 2010, in the Little Maquoketa River and Maquoketa River Basins, Northeast lowa}

By David A. Eash

Prepared in cooperation with the lowa Department of Transportation and lowa Highway Research Board (Project HR-140)

Open-File Report 2011-1301 


\title{
U.S. Department of the Interior \\ KEN SALAZAR, Secretary \\ U.S. Geological Survey \\ Marcia K. McNutt, Director
}

\author{
U.S. Geological Survey, Reston, Virginia: 2012
}

For more information on the USGS - the Federal source for science about the Earth, its natural and living resources, natural hazards, and the environment, visit http://www.usgs.gov or call 1-888-ASK-USGS.

For an overview of USGS information products, including maps, imagery, and publications,

visit http://www.usgs.gov/pubprod

To order this and other USGS information products, visit http://store.usgs.gov

Any use of trade, product, or firm names is for descriptive purposes only and does not imply endorsement by the U.S. Government.

Although this report is in the public domain, permission must be secured from the individual copyright owners to reproduce any copyrighted materials contained within this report.

Suggested citation:

Eash, D.A., 2012, Floods of July 23-26, 2010, in the Little Maquoketa River and Maquoketa River Basins, Northeast lowa: U.S. Geological Survey Open-File Report 2011-1301, 45 p. with appendix. 


\section{Acknowledgments}

The author expresses his gratitude to the following: Harry Hillaker, State Climatologist, lowa Department of Agriculture and Land Stewardship, for providing an isohyetal map of rainfall for the 72-hour period ending 7:00 a.m. on July 24, 2010; Bonnie Shepard, National Flood Insurance Program Bureau and Statistical Agent, Federal Emergency Management Agency, for providing private property damage claims for nine counties in lowa; and Dennis Harper, State Hazard Mitigation Officer, lowa Homeland Security and Emergency Management Division, for providing public assistance project costs for nine counties in lowa.

The author also expresses gratitude to the following U.S. Geological Survey employees: Mike Linhart, Brian Imig, Doug Goodrich, Kevin Townsend, Garret Welsh, Jon Nania, and Clint Van Schepen for collecting field data for the determination of water-surface and bench-mark elevations listed in this report; and Kaylene Carney for obtaining newspaper articles for the compilation of flood description information.

\section{Contents}

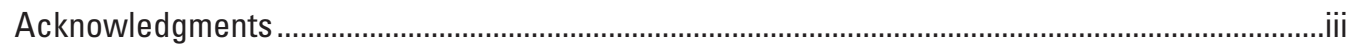

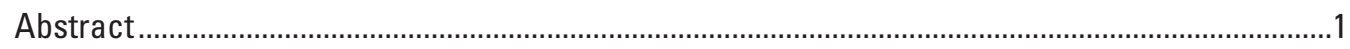

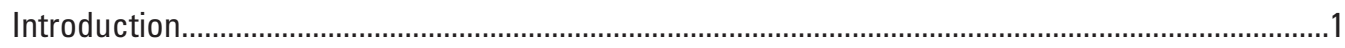

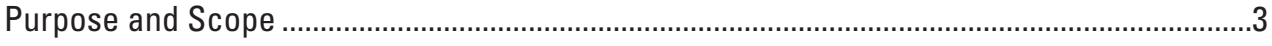

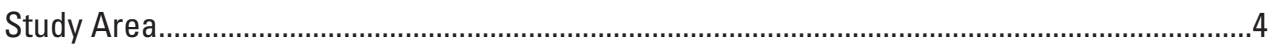

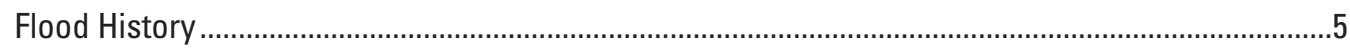

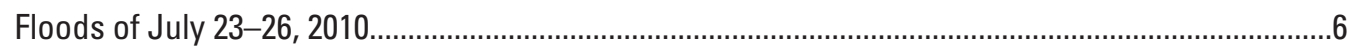

Annual Flood Probability ....................................................................................................

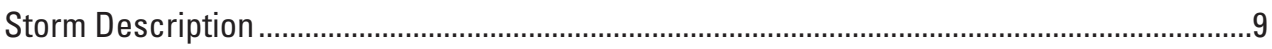

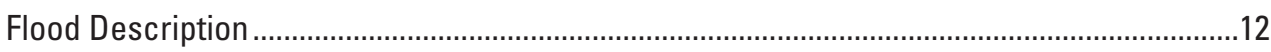

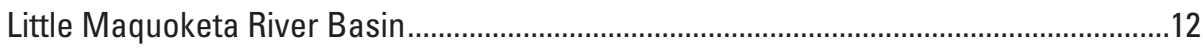

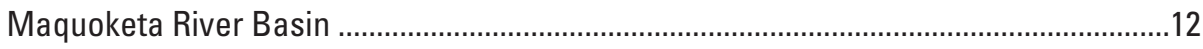

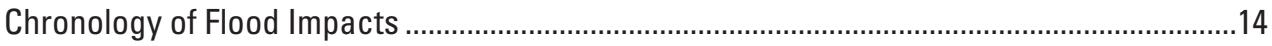

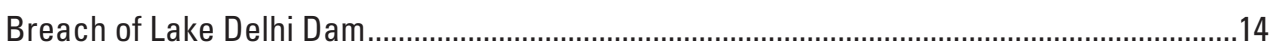

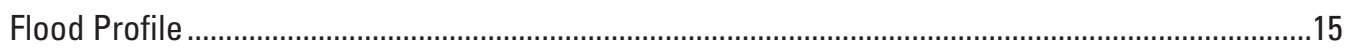

Summary

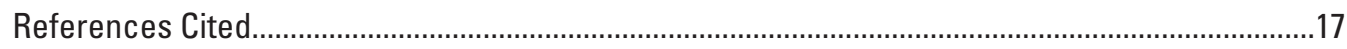

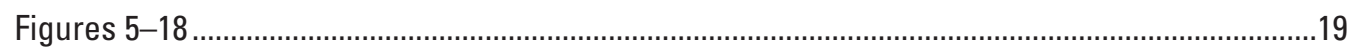

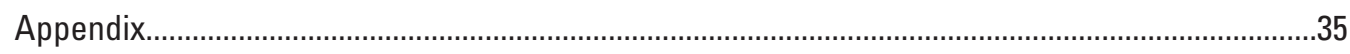

List of Bench Marks and Reference Points.............................................................................36 


\section{Figures}

1. Map showing Little Maquoketa River and Maquoketa River Basins and lines of equal rainfall for 72 hours ending at 7:00 a.m. on July 24, 2010

2. Map showing Little Maquoketa River and Maquoketa River Basins and landform regions of lowa......

3. Graphs showing hourly rainfall for July $22-24,2010$, at three rain gages in the Maquoketa River Basin and vicinity.

4. Graphs showing discharge hydrographs for streamgages on the Maquoketa River and the North Fork Maquoketa River, July 22-29, 2010.

5. Graph showing profile of the July 23, 2010, flood for the Little Maquoketa River and the North Fork Little Maquoketa River, river miles 4 to 23.

6. Graph showing profile of the July 23, 2010, flood for the Little Maquoketa River and the North Fork Little Maquoketa River, river miles 4 to 12 .

7. Graph showing profile of the July 23, 2010, flood for the North Fork Little Maquoketa River, river miles 12 to 23

8. Graph showing profile of the July 23-26, 2010, flood for the Maquoketa River, river miles 2 to 144

9. Graph showing profile of the July 23-26, 2010, flood for the Maquoketa River, river miles 2 to 30

10. Graph showing profile of the July 23-26, 2010, flood for the Maquoketa River, river miles 30 to 60

11. Graph showing profile of the July 23-26, 2010, flood for the Maquoketa River, river miles 60 to 90

12. Graph showing profile of the July $23-26,2010$, flood for the Maquoketa River, river miles 90 to 120 .

13. Graph showing profile of the July 23-26, 2010, flood for the Maquoketa River, river miles 120 to 144

14. Graph showing profile of the July 23-24, 2010, flood for the North Fork Maquoketa River, river miles 0 to 90 .

15. Graph showing profile of the July 23-24, 2010, flood for the North Fork Maquoketa River, river miles 0 to 25

16. Graph showing profile of the July 23-24, 2010, flood for the North Fork Maquoketa River, river miles 25 to 50 .

17. Graph showing profile of the July 23-24, 2010, flood for the North Fork Maquoketa River, river miles 50 to 75 .

18. Graph showing profile of the July 23-24, 2010, flood for the North Fork Maquoketa River, river miles 75 to 100 . 


\section{Tables}

1. National Flood Insurance Program Bureau and Statistical Agent lowa claims closed with payment for selected counties, July 23-26, 2010, dates of loss, as of February 28, 2011

2. Iowa Public Assistance Program project costs for selected counties for disaster number 1930, June-August 2010, as of April 29, 2011

3. Maximum stages and discharges for 2010 and selected largest-flood years, and the corresponding annual flood-probability ranges, at streamgages in the Little Maquoketa River and Maquoketa River Basins, lowa...

4. Annual flood probability and equivalent flood recurrence interval for selected probabilities

5. Twenty-four-hour rainfall amounts at selected rain gages in northeast and east-central lowa during July 22-24, 2010

6. Magnitude and annual probability of theoretical rainfall amounts for selected storm periods in the East-Central and Northeast lowa Climatological Divisions .11

7. Locations and elevations of high-water marks used in the Little Maquoketa River and North Fork Little Maquoketa River flood profiles of July 23, 2010.

8. Locations and elevations of high-water marks used in the Maquoketa River flood profile of July 23-26, 2010. 16

9. Locations and elevations of high-water marks used in the North Fork Maquoketa River flood profile of July 23-24, 2010. . .16

\section{Appendix Table}

1. Bench marks and reference points used in the July 23-26, 2010, Little Maquoketa River, North Fork Little Maquoketa River, Maquoketa River, and North Fork Maquoketa River flood profiles. 


\section{Conversion Factors and Datums}

Inch/Pound to SI

\begin{tabular}{|c|c|c|}
\hline Multiply & By & To obtain \\
\hline \multicolumn{3}{|c|}{ Length } \\
\hline inch (in.) & 2.54 & centimeter $(\mathrm{cm})$ \\
\hline foot $(\mathrm{ft})$ & 0.3048 & meter $(\mathrm{m})$ \\
\hline mile (mi) & 1.609 & kilometer (km) \\
\hline \multicolumn{3}{|c|}{ Area } \\
\hline square mile $\left(\mathrm{mi}^{2}\right)$ & 2.590 & square kilometer $\left(\mathrm{km}^{2}\right)$ \\
\hline \multicolumn{3}{|c|}{ Flow rate } \\
\hline cubic foot per second $\left(\mathrm{ft}^{3} / \mathrm{s}\right)$ & 0.02832 & cubic meter per second $\left(\mathrm{m}^{3} / \mathrm{s}\right)$ \\
\hline
\end{tabular}

Elevation or vertical coordinate information is referenced to the National Geodetic Vertical Datum of 1929 (NGVD 29). Elevation refers to distance above or below NGVD 29. NGVD 29 can be converted to the North American Vertical Datum of 1988 by using the National Geodetic Survey conversion utility available at $h t t p: / / w w w . n g s . n o a a . g o v / T O O L S /$ Vertcon/vertcon.html.

Horizontal coordinate information is referenced to the North American Datum of 1983 (NAD 83).

Map projections are Universal Transverse Mercator, Zone 15

Water year is the 12-month period from 0ctober 1 through September 30. The water year is designated by the calendar year in which the water year ends and that includes 9 of the 12 months. Thus, the water year ending September 30, 2010, is called the "2010 water year." 


\title{
Floods of July 23-26, 2010, in the Little Maquoketa River and Maquoketa River Basins, Northeast lowa
}

\author{
By David A. Eash
}

\section{Abstract}

Minor flooding occurred July 23, 2010, in the Little Maquoketa River Basin and major flooding occurred July 23-26, 2010, in the Maquoketa River Basin in northeast Iowa following severe thunderstorm activity over the region during July 22-24. A breach of the Lake Delhi Dam on July 24 aggravated flooding on the Maquoketa River. Rain gages at Manchester and Strawberry Point, Iowa, recorded 72-hour-rainfall amounts of 7.33 and 12.23 inches, respectively, on July 24 . The majority of the rainfall occurred during a 48-hour period. Within the Little Maquoketa River Basin, a peak-discharge estimate of 19,000 cubic feet per second (annual flood-probability estimate of 4 to 10 percent) at the discontinued 05414500 Little Maquoketa River near Durango, Iowa streamgage on July 23 is the sixth largest flood on record. Within the Maquoketa River Basin, peak discharges of 26,600 cubic feet per second (annual flood-probability estimate of 0.2 to 1 percent) at the 05416900 Maquoketa River at Manchester, Iowa streamgage on July 24, and of 25,000 cubic feet per second (annual flood-probability estimate of 1 to 2 percent) at the 05418400 North Fork Maquoketa River near Fulton, Iowa streamgage on July 24 are the largest floods on record for these sites. A peak discharge affected by the Lake Delhi Dam breach on July 24 at the 05418500 Maquoketa River near Maquoketa, Iowa streamgage, located downstream of Lake Delhi, of 46,000 cubic feet per second on July 26 is the third highest on record.

High-water marks were measured at five locations along the Little Maquoketa and North Fork Little Maquoketa Rivers between U.S. Highway 52 near Dubuque and County Road Y21 near Rickardsville, a distance of 19 river miles. Highwater marks were measured at 28 locations along the Maquoketa River between U.S. Highway 52 near Green Island and State Highway 187 near Arlington, a distance of 142 river miles. High-water marks were measured at 13 locations along the North Fork Maquoketa River between Rockdale Road near Maquoketa and U.S. Highway 52 near Luxemburg, a distance of 90 river miles. The high-water marks were used to develop flood profiles for the Little Maquoketa, North Fork Little Maquoketa, Maquoketa, and North Fork Maquoketa Rivers.

\section{Introduction}

Severe thunderstorms during July 22-24, 2010, following record statewide precipitation in June, caused minor flooding on the Little Maquoketa River and record flooding on the Maquoketa and North Fork Maquoketa Rivers, in northeast Iowa during July 23-26, 2010. New maximum peak discharges were recorded on July 24, 2010, at streamgages 05416900 Maquoketa River at Manchester, Iowa (fig. 1, site 8 ) and 05418400 North Fork Maquoketa River near Fulton (fig. 1, site 15). Record flooding on the Maquoketa River in the vicinity of Manchester led to the breach of the Lake Delhi Dam downstream of Manchester on July 24. The July 22-24 storms also caused significant flooding in parts of adjacent watersheds and along reaches of the Turkey, Volga, and Wapsipinicon Rivers (fig. 1).

Because of the flooding in the Little Maquoketa River and Maquoketa River Basins, the counties of Buchanan, Clayton, Delaware, Dubuque, Jackson, and Jones were added to a State disaster proclamation during July 23-26, 2010, which authorized implementation of the State Individual Assistance Grant Program to assist eligible residents of those counties (http://www.iowahomelandsecurity.org/news_room/ press_releases.html, accessed July 5, 2011). A Federal disaster declaration (number 1930) was issued on July 29, 2010, to help Iowans recover from losses caused by severe storms, flooding, and tornados for the incident period June 1 to August 31, 2010 (Federal Emergency Management Agency, 2010). The Federal disaster declaration requested individual assistance for 38 counties and public assistance for 59 counties in Iowa. Private property damage claims reported for residential and nonresidential buildings in nine selected counties in northeast Iowa are shown in table 1 (Bonnie Shepard, Federal Emergency Management Agency, National Flood Insurance Program Bureau and Statistical Agent, written commun., May 2011). Approved public assistance costs (assistance to local governments for the repair of disaster-damaged public facilities) for the same nine counties in Iowa are shown in table 2 (Dennis Harper, Iowa Homeland Security and Emergency Management Division, State Hazard Mitigation Officer, written commun., April 2011). 


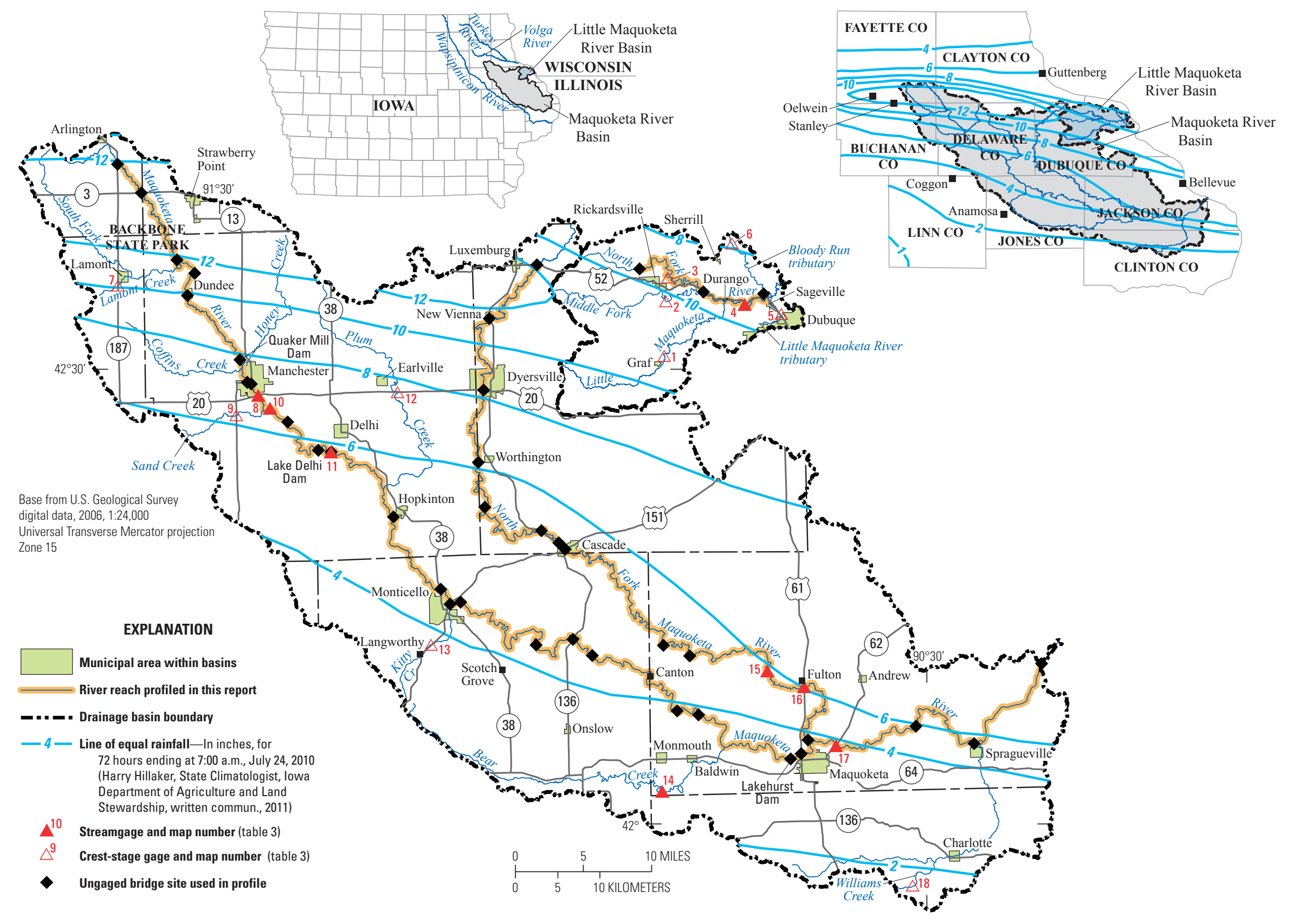

Figure 1. Little Maquoketa River and Maquoketa River Basins and lines of equal rainfall for 72 hours ending at 7:00 a.m. on July 24, 2010. 
Table 1. National Flood Insurance Program Bureau and Statistical Agent lowa claims closed with payment for selected counties, July 23-26, 2010, dates of loss, as of February 28, 2011.

[Source: Bonnie Shepard, Federal Emergency Management Agency, National Flood Insurance Program Bureau and Statistical Agent, written commun., May 2011. NC, no claims]

\begin{tabular}{lcc}
\hline County & $\begin{array}{c}\text { Number } \\
\text { of claims }\end{array}$ & $\begin{array}{c}\text { Damage payment } \\
\text { (dollars) }\end{array}$ \\
\hline Buchanan & 18 & 97,125 \\
Clayton & 1 & 35,754 \\
Clinton & $\mathrm{NC}$ & $\mathrm{NC}$ \\
Delaware & 27 & $1,425,560$ \\
Dubuque & 8 & 178,003 \\
Fayette & 7 & 31,185 \\
Jackson & $\mathrm{NC}$ & $\mathrm{NC}$ \\
Jones & 12 & $1,244,501$ \\
Linn & 4 & 40,883 \\
Total & $\mathbf{7 7}$ & $\mathbf{3 , 0 5 3 , 0 1 1}$ \\
\hline
\end{tabular}

\section{Purpose and Scope}

This report is part of an on-going program of preparing water-surface profiles of major floods on streams in Iowa. The program is managed by the U.S. Geological Survey (USGS) in cooperation with the Iowa Department of Transportation (Iowa DOT) and the Iowa Highway Research Board (Project HR-140). Flood-peak and water-surface-elevation profile information is needed for the economical and safe location and design of bridges and other structures on or over streams and the adjacent flood plains. Defining the limits of flood inundation and establishing encroachment limits on flood plains are related issues dependent on this information. Data for major floods are needed to compute annual flood-probability discharges and to calibrate water-surface-elevation profile models for sites along streams. A list of other USGS flood-profile reports for Iowa can be obtained by accessing http://ia.water. usgs.gov/projects/profiles/.

This report provides information about July 22-24, 2010, rainfall and flooding during July 23-26, 2010, in the Little Maquoketa River and Maquoketa River Basins, and estimated annual flood-probability ranges at eight continuousrecord streamgages and ten crest-stage gages (CSG) in the basins. High-water marks (HWMs) at selected sites along the Little Maquoketa and North Fork Little Maquoketa Rivers are presented in a flood profile from U.S. Highway 52 near Dubuque to County Road Y21 (not shown in fig. 1) near Rickardsville, a distance of 19 river miles. HWMs at selected sites along the Maquoketa River are presented in a flood profile from U.S. Highway 52 near Green Island (not shown in fig. 1) to State Highway 187 near Arlington, a distance of 142 river miles. HWMs at selected sites along the North Fork

Table 2. Iowa Public Assistance Program project costs for selected counties for disaster number 1930, June-August 2010, as of April 29, 2011.

[Source: Dennis Harper, Iowa Homeland Security and Emergency Management Division, State Hazard Mitigation Officer, written commun., April 29, 2011. NC, no claims]

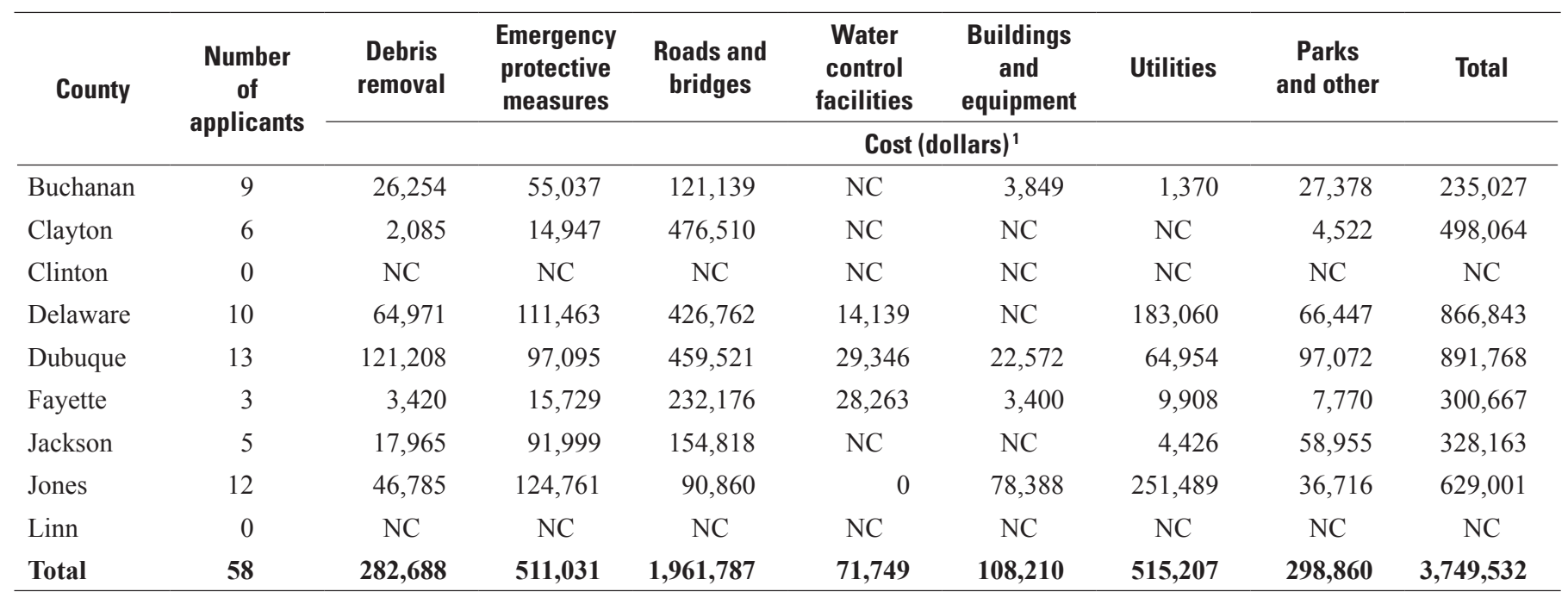

\footnotetext{
${ }^{1}$ Cost rounded to whole dollars.
} 
Maquoketa River are presented in a flood profile from Rockdale Road (not shown in fig. 1) near Maquoketa to U.S. Highway 52 near Luxemburg, a distance of 90 river miles.

\section{Study Area}

The Little Maquoketa River and Maquoketa River Basins are adjacent watersheds in northeast Iowa with the Little Maquoketa River Basin draining from west to east and the Maquoketa River Basin draining from northwest to southeast. The two drainage basins, the river reaches profiled, the location of USGS streamgages within these river basins, and the location of bridge sites used in the July 23-26, 2010, flood profiles are shown in figure 1. The Little Maquoketa
River and Maquoketa River Basins lie within three of Iowa's landform regions (fig. 2), the Iowan Surface, the East-Central Iowa Drift Plain, and the Paleozoic Plateau. The Iowan Surface landform region is a low-relief plain with wellestablished, low-gradient drainage networks. Topography of this region appears slightly inclined to gently rolling with long slopes and open views to the horizon (Prior, 1991). Soils of this region are characterized as thin, discontinuous loess or loam and clay loam over glacial drift (Prior, 1991; Oschwald and others, 1965). The East-Central Iowa Drift Plain is similar to the Southern Iowa Drift Plain, and was formerly included as part of the Southern Iowa Drift Plain and the Iowan Surface, but is now considered a separate landform because of its uniqueness (Prior and others, 2009). This region differs from the Southern Iowa Drift Plain with

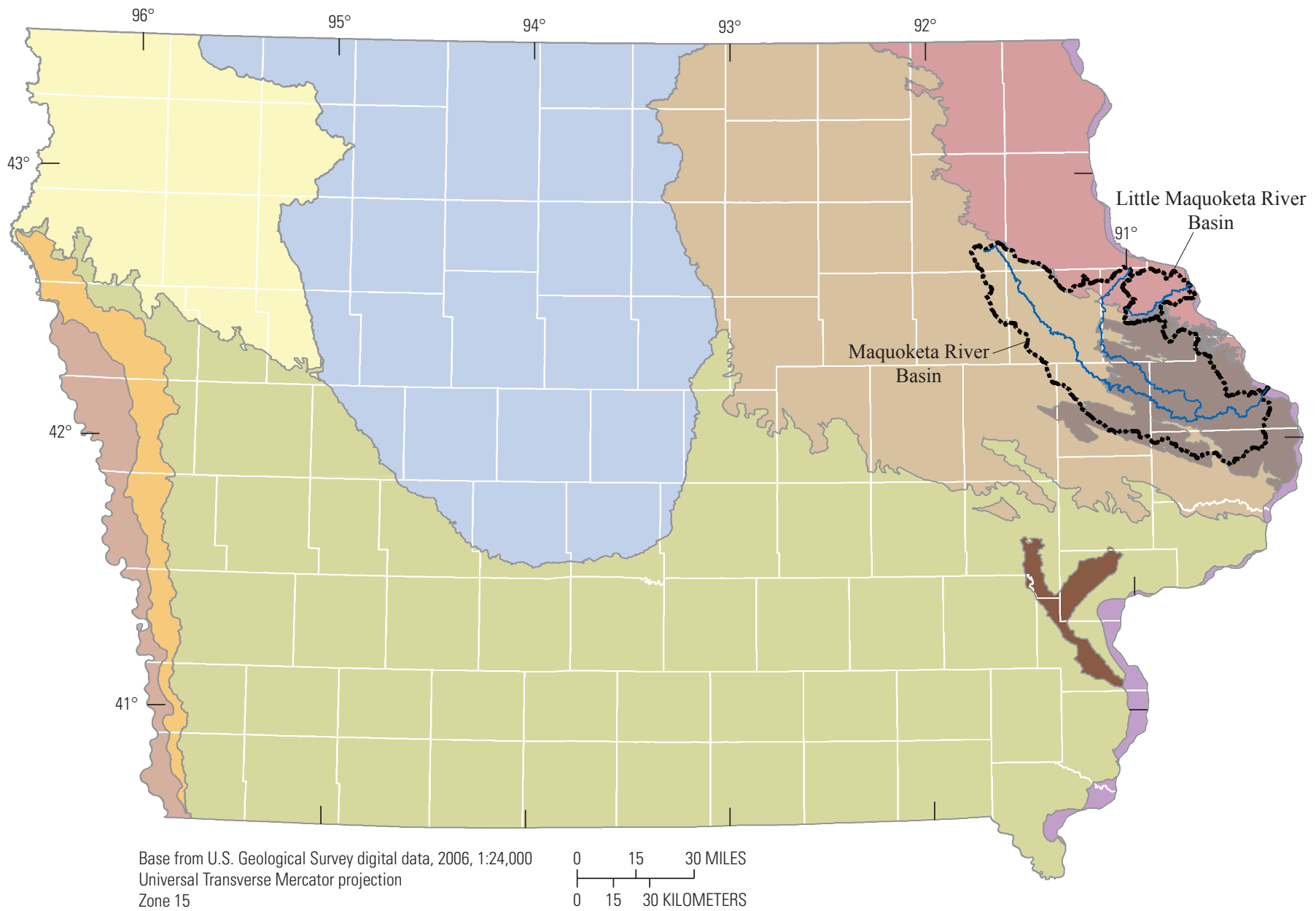

EXPLANATION

Landform region

[Priot, Kohrt, and Quade, lowa Geological Survey, 2006 (edited 2009)]

\begin{tabular}{|l|l|}
\hline & Des Moines Lobe \\
& East-Central lowa Drift Plain \\
& lowa-Cedar Lowland \\
\hline & lowan Surface \\
\hline & Loess Hills \\
\hline$\square$
\end{tabular}

Mississippi River Alluvial Plain

Missouri River Alluvial Plain

Northwest lowa Plains

Paleozoic Plateau

Southern lowa Drift Plain

Figure 2. Little Maquoketa River and Maquoketa River Basins and landform regions of lowa. 
bedrock closer to the surface and more bedrock outcropping. Topography of the region consists of steeply rolling hills and valleys. A mantle of loess covers the uplands and upper hill slopes. Soils in this region are characterized as loess over glacial till or limestone bedrock (Oschwald and others, 1965). The Paleozoic Plateau landform region has a bedrockdominated, erosional topography that is characterized by plateau-like uplands, integrated drainage networks with steep gradients, and deeply entrenched valleys (Prior, 1991; Horick and Soenksen, 1989; Iowa Natural Resources Council, 1958). Stream erosion and hillslope development have stripped away glacial deposits from all but limited areas of this region. Karst topography exists in the Paleozoic Plateau where carbonate rocks are present at depths of less than 50 feet (ft) beneath the land surface. Dissolution of these carbonate rocks (limestone and dolomite) by groundwater enlarges cracks and crevices in the bedrock which can result in surface depressions, sinkholes, caves, caverns, and springs. Where sinkholes have formed in streambeds, streams can abruptly disappear, as surface-water runoff is captured and redirected to groundwater flow or to re-emerge at springs. Soils in this region are characterized as thin loess and glacial drift over bedrock or clay loam till (Prior, 1991; Oschwald and others, 1965). Extensive descriptions of the landform regions are available from Prior (1991) and Prior and others (2009).

The Little Maquoketa River Basin lies entirely within Dubuque County just northwest of the city of Dubuque, Iowa and drains 157 square miles $\left(\mathrm{mi}^{2}\right)$ (Larimer, 1957). The Little Maquoketa River flows about 30 miles (mi) from drainage divide to its mouth at the Mississippi River in northeast Dubuque County; major tributaries include the Middle Fork Little Maquoketa River with a drainage area of $33.2 \mathrm{mi}^{2}$ and the North Fork Little Maquoketa River with a drainage area of $70.0 \mathrm{mi}^{2}$ that includes the entire Middle Fork Little Maquoketa River Basin (Larimer, 1957). Basin topography is rugged, with many small valleys bounded by steep hills. The lowlands are predominately agricultural and the hillslopes are in forest and pasture. The region is sometimes referred to as the "Little Switzerland of Iowa" (Heinitz, 1973). No dams have been constructed across the Little Maquoketa River or its tributaries (Iowa Conservation Commission, 1979).

The Maquoketa River Basin originates in Fayette County and flows about $150 \mathrm{mi}$ through the cities of Manchester, Monticello, and Maquoketa to its mouth at the Mississippi River in eastern Jackson County (fig. 1). The Maquoketa River Basin includes parts of nine counties and drains $1,879 \mathrm{mi}^{2}$ (Larimer, 1957). The North Fork Maquoketa River, a major tributary to the Maquoketa River with a drainage area of $592 \mathrm{mi}^{2}$ (Larimer, 1957), originates in Dubuque County and flows about $97 \mathrm{mi}$ through the cities of New Vienna, Dyersville, and Cascade to its mouth in Jackson County. In northwest Delaware County, the Maquoketa River valley changes for a few miles from a gently sloped valley to a rugged gorge in Backbone State Park. Farther downstream in central Delaware County, a few miles southeast of Manchester, the Maquoketa River enters a canyon-like valley that persists throughout much of the remaining length of the river (Iowa Natural Resources Council, 1958). Land use in the basin is predominately agricultural and includes some wooded areas. Eight low-head dams have been constructed across the Maquoketa River (Iowa Conservation Commission, 1979); no dams have been constructed across the North Fork Maquoketa River. Six of the dams on the Maquoketa River were originally built for hydroelectric power (Iowa Natural Resources Council, 1958); only the Lakehurst Dam upstream from the city of Maquoketa in Jackson County (fig. 1) is currently operating as a hydroelectric dam. Prior to its breach on July 24, 2010, the Lake Delhi Dam was the largest dam on the Maquoketa River, at a height of $38 \mathrm{ft}$ (Iowa Conservation Commission, 1979). Lake Delhi (federally recognized as Hartwick Lake) was approximately $8 \mathrm{mi}$ in length and 450 acres in area prior to the breach of the dam. The local name "Lake Delhi" was adopted by area residents in recognition of the nearby town of Delhi in Delaware County (fig. 1).

\section{Flood History}

Floods on the Little Maquoketa River have been well documented during the operation of the streamgage 05414500 Little Maquoketa River near Durango (fig.1, site 4) during water years 1935-2000. The only other flood data recorded in the Little Maquoketa River Basin prior to streamgage operation were for the 1925 flood that was documented by the U.S. Army Corps of Engineers (Heinitz, 1973). Heinitz (1973) briefly describes six major storm events $(1876,1918$, $1919,1925,1937$, and 1947) that occurred in the Dubuque area; descriptions for three of these storms are noteworthy for reprinting in this report.

Storm of 1876.- One of the largest storms recorded in the area occurred on July 4, 1876, when 40 people were drowned at Rockdale (not shown in fig. 1) on the outskirts of Dubuque. Rainfall of 4.55 inches in 2 hours and 5 minutes was recorded at Dubuque.

Storm of 1919.-A storm on July 9, 1919, caused the deaths of seven people. Flooding was the result of 3.81 inches of rain in 4 hours. Great damage occurred to streets in all portions of the city (Dubuque) lying below the bluffs. The USGS made a computation of discharge on the Little Maquoketa River tributary at Dubuque. This is the same stream on which the streamgage 05414600 was located (fig. 1, site 5); however, the discharge computation of 3,000 cubic feet per second $\left(\mathrm{ft}^{3} / \mathrm{s}\right)$ was made for a site $0.25 \mathrm{mi}$ upstream from the streamgage with a drainage area of $1.07 \mathrm{mi}^{2}$ and this discharge is not entered into the flood record for the streamgage.

Storm of 1925.-Rainfall for the month of June at Dubuque was 10.80 inches with most of this resulting from four heavy rainstorms between June 11 and 24 . The greatest of these storms occurred on the night of June 14-15 when 3.15 inches of rain fell between 10 p.m. and 4 a.m. A discharge of 29,000 $\mathrm{ft}^{3} / \mathrm{s}$ for the Little Maquoketa River near 
Floods of July 23-26, 2010, in the Little Maquoketa River and Maquoketa River Basins, Northeast lowa

Durango was computed by the U.S. Army Corps of Engineers by an indirect measurement. On the Sageville road, this flood was reported to be $0.4 \mathrm{ft}$ higher than the previous record of July 1919.

The flood of August 2, 1972, is the largest known flood in the Little Maquoketa River Basin. A peak discharge of $40,000 \mathrm{ft}^{3} / \mathrm{s}$ (annual flood-probability estimate of less than 0.2 percent) was recorded at the discontinued streamgage 05414500 Little Maquoketa River near Durango (fig. 1, site 4). The 1972 flood is also the greatest flood on record at streamgage 05414400 Middle Fork Little Maquoketa River (fig. 1, site 2) with a discharge of $23,000 \mathrm{ft}^{3} / \mathrm{s}$ (annual floodprobability estimate of 0.2 to 1 percent). As much as 9 inches of rain fell in the headwater of the Middle Fork Little Maquoketa River with 6 to 7 inches occurring over most of the Little Maquoketa River Basin (Heinitz, 1973). Flood damages were extensive to crops, roads, and bridges. Many of the homes in Durango, Daytonville (not shown in fig. 1), and Sageville were inundated to some extent and were evacuated. Flood damages were estimated to be greater than 1 million dollars (Heinitz, 1973).

Continuous records of streamflow have been collected in the Maquoketa River Basin since September 1913 at streamgage 05418500 Maquoketa River near Maquoketa (fig. 1, site 17). Descriptions of historic floods in the Maquoketa River Basin are limited; available information is summarized for floods that occurred in the Maquoketa River Basin in 1925, 1944, 1947, and 2002 in the report Flood of June 4-5, 2002, in the Maquoketa River Basin, East-Central Iowa (Eash, 2005), and is summarized for the flood that occurred in 2004 in the report Flood of May 23, 2004, in the Turkey and Maquoketa River Basins, Northeast Iowa (Eash, 2006).

Peak stages and discharges, and the corresponding annual flood-probability ranges for the largest known floods, including the July 2010 flood, are listed in table 3 for streamgages in the Little Maquoketa River and Maquoketa River Basins. The streamgages listed in table 3 also are listed in the USGS National Water Information System (NWIS) database, and users may obtain surface-water data for Iowa streamgages, including information on types of data available and years of data collection, at http://waterdata.usgs.gov/ia/nwis/sw.

\section{Floods of July 23-26, 2010}

The floods of July 23-26, 2010, are some of the largest floods on record in the Maquoketa River Basin (table 3). The 2010 flood is the largest flood on record at streamgages 05416900 Maquoketa River at Manchester (fig. 1, site 8) and 05418400 North Fork Maquoketa River near Fulton (fig. 1, site 15). At streamgage 05418500 Maquoketa River near Maquoketa (fig. 1, site 17), the 2010 flood is the third largest flood on record; the peak discharge of the 2010 flood at this site was affected by the Lake Delhi Dam breach on July 24 . Within the Little Maquoketa River Basin, the flood at the discontinued streamgage 05414500 Little Maquoketa River near Durango (fig. 1, site 4) is the sixth largest flood on record.

\section{Annual Flood Probability}

Annual flood probability, also referred to as annual exceedance probability, is an estimate of the likelihood of a flood of a specific magnitude occurring in any 1 year, and an annual flood-probability range expresses the uncertainty of estimating precise annual flood probabilities. The reporting ranges are as follows: greater than 10 percent, 4 to 10 percent, 2 to 4 percent, 1 to 2 percent, 0.2 to 1 percent, and less than 0.2 percent. The range is determined from the estimated annual flood-probability discharges that bracket the observed flood-peak discharge. If the observed peak discharge is the same value as an estimated annual flood-probability discharge, the lower annual flood-probability range is used. In the "Flood Description" section, flood discharges and their respective annual flood-probability ranges are discussed and are listed in table 3. Unless noted otherwise, annual floodprobability estimates listed in table 3 were computed using the Weighting of Independent Estimates (WIE) program (Charles Berenbrock and Tim Cohn, U.S. Geological Survey, written commun., 2008) following guidelines in appendix 8 of Bulletin 17B (Interagency Advisory Committee on Water Data, 1982). The WIE program uses the variance and estimate of the Bulletin 17B annual streamgage-probability analysis and the variance and estimate of the regional-regression annual probability calculation (Eash, 2001) to compute a weighted estimate and variance at a streamgage. As noted in table 3, the WIE program was not used to estimate annual flood probabilities for streamgages with basin characteristic values outside of the applicable range of characteristic values used to develop the regional-regression annual probability calculations, in which case only Bulletin 17B annual streamgage-probability analyses were used.

Annual flood probabilities change as streamflow records get longer. Bulletin 17B annual probability analyses are computed for streamgages using annual peak-discharge data. As additional annual peak discharges are measured at streamgages, Bulletin 17B annual probability estimates are updated and become more statistically reliable. A minimum of 10 years of record is required to compute Bulletin 17B annual streamgage-probability estimates.

Annual flood probabilities formerly were reported as flood recurrence intervals expressed in years. For example, a 1-percent annual flood-probability discharge is the same as the 100-year recurrence-interval flood discharge. But, because of widespread confusion caused in recent years by two or more "100-year floods" occurring in a period of much less than 100 years, the scientific and engineering community has begun expressing the annual likelihood of occurrence of flood discharges as a probability. Percent probability is the inverse of the recurrence interval multiplied by 100 . Selected annual flood probabilities and equivalent flood recurrence intervals 
Table 3. Maximum stages and discharges for 2010 and selected largest-flood years, and the corresponding annual flood-probability ranges, at streamgages in the Little Maquoketa River and Maquoketa River Basins, lowa.

$\left[\mathrm{mi}^{2}\right.$, square miles; $\mathrm{ft}$, feet; $\mathrm{ft}^{3} / \mathrm{s}$, cubic feet per second; $\left(\mathrm{ft}^{3} / \mathrm{s}\right) / \mathrm{mi}^{2}$, cubic feet per second per square mile; $>$, greater than; <, less than; --, not determined]

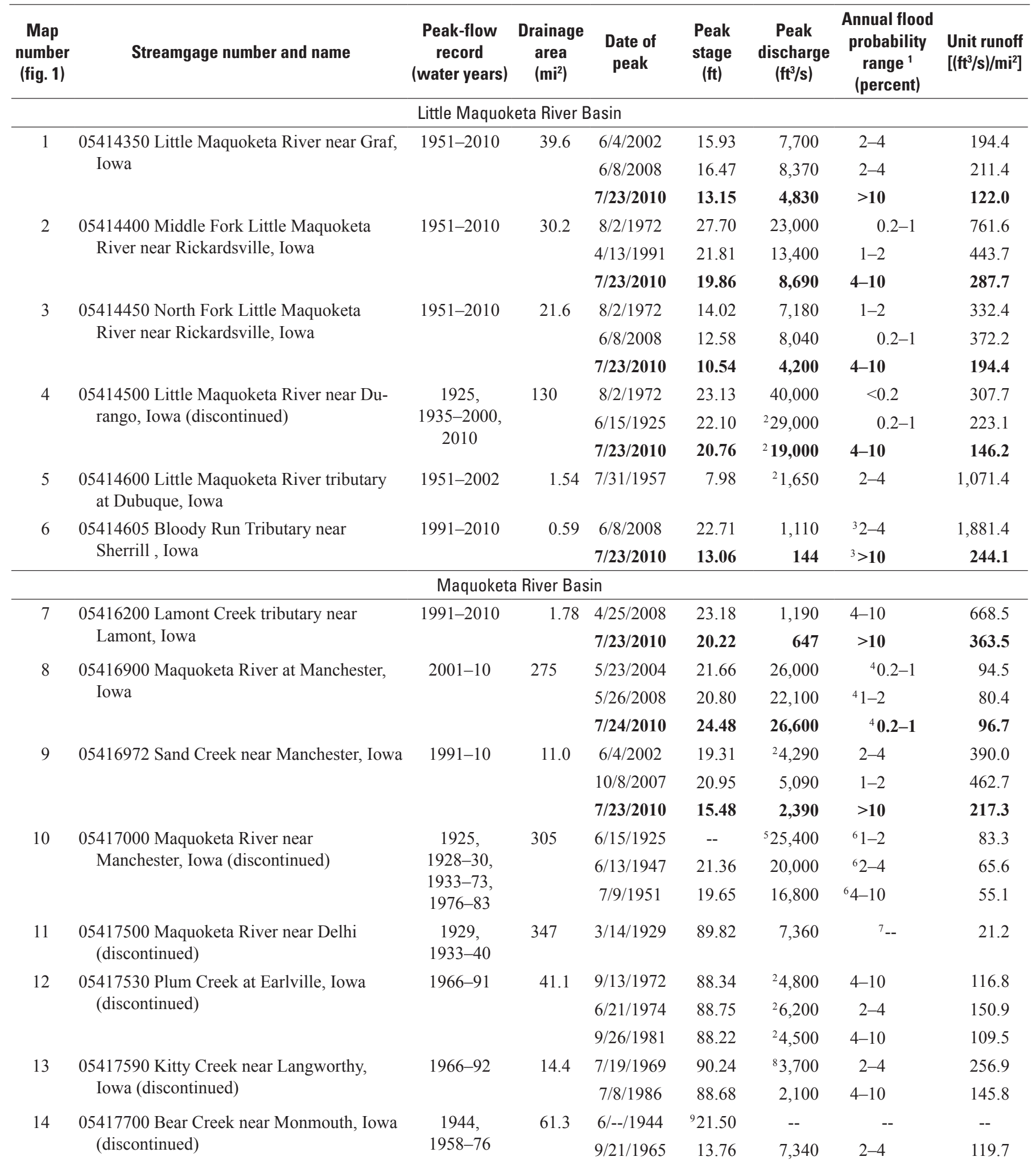


Table 3. Maximum stages and discharges for 2010 and selected largest-flood years, and the corresponding annual flood-probability ranges, at streamgages in the Little Maquoketa River and Maquoketa River Basins, lowa.-Continued

$\left[\mathrm{mi}^{2}\right.$, square miles; $\mathrm{ft}$, feet; $\mathrm{ft}^{3} / \mathrm{s}$, cubic feet per second; $\left(\mathrm{ft}^{3} / \mathrm{s}\right) / \mathrm{mi}^{2}$, cubic feet per second per square mile; >, greater than; <, less than; --, not determined]

\begin{tabular}{|c|c|c|c|c|c|c|c|c|}
\hline $\begin{array}{c}\text { Map } \\
\text { number } \\
\text { (fig. 1) }\end{array}$ & Streamgage number and name & $\begin{array}{l}\text { Peak-flow } \\
\text { record } \\
\text { (water years) }\end{array}$ & $\begin{array}{c}\text { Drainage } \\
\text { area } \\
\left(\mathrm{mi}^{2}\right)\end{array}$ & $\begin{array}{l}\text { Date of } \\
\text { peak }\end{array}$ & $\begin{array}{c}\text { Peak } \\
\text { stage } \\
\text { (ft) }\end{array}$ & $\begin{array}{c}\text { Peak } \\
\text { discharge } \\
\left(\mathrm{ft}^{3} / \mathbf{s}\right)\end{array}$ & $\begin{array}{c}\text { Annual flood } \\
\text { probability } \\
\text { range } 1 \\
\text { (percent) }\end{array}$ & $\begin{array}{l}\text { Unit runoff } \\
{\left[\left(\mathrm{ft}^{3} / \mathrm{s}\right) / \mathrm{mi}^{2}\right]}\end{array}$ \\
\hline \multicolumn{9}{|c|}{ Maquoketa River Basin—Continued } \\
\hline \multirow[t]{3}{*}{15} & \multirow{3}{*}{$\begin{array}{l}05418400 \text { North Fork Maquoketa River near } \\
\text { Fulton, Iowa }\end{array}$} & \multirow[t]{3}{*}{ 1999-2010 } & \multirow[t]{3}{*}{505} & $6 / 5 / 2002$ & 19.87 & 22,600 & ${ }^{10} 2-4$ & 44.8 \\
\hline & & & & $6 / 13 / 2008$ & 18.67 & 20,700 & ${ }^{10} 2-4$ & 41.0 \\
\hline & & & & $7 / 24 / 2010$ & 22.44 & 25,000 & ${ }^{10} 1-2$ & 49.5 \\
\hline 16 & $\begin{array}{l}05418450 \text { North Fork Maquoketa River at } \\
\text { Fulton, Iowa (discontinued) }\end{array}$ & $\begin{array}{c}1974, \\
1977-91 \\
2002\end{array}$ & 516 & $6 / 5 / 2002$ & 21.21 & ${ }^{2} 22,600$ & $2-4$ & 43.8 \\
\hline \multirow[t]{4}{*}{17} & \multirow{4}{*}{$\begin{array}{l}05418500 \text { Maquoketa River near Maquoketa, } \\
\text { Iowa }\end{array}$} & \multirow{4}{*}{$\begin{array}{c}1903, \\
1914-2010\end{array}$} & \multirow[t]{4}{*}{1,553} & $--/--/ 1903$ & ${ }^{11} 23.50$ & 43,200 & $2-4$ & 27.8 \\
\hline & & & & $6 / 27 / 1944$ & ${ }^{11} 24.70$ & 48,000 & $1-2$ & 30.9 \\
\hline & & & & $6 / 5 / 2002$ & 34.09 & 47,900 & $1-2$ & 30.8 \\
\hline & & & & $7 / 26 / 2010$ & 35.26 & ${ }^{12} 46,000$ & ${ }^{13}-$ & ${ }^{12} \mathbf{2 9 . 6}$ \\
\hline \multirow[t]{2}{*}{18} & \multirow{2}{*}{$\begin{array}{l}5418645 \text { Williams Creek near Charlotte, } \\
\text { Iowa }\end{array}$} & \multirow[t]{2}{*}{ 1989-2010 } & \multirow[t]{2}{*}{1.77} & $5 / 29 / 1996$ & 13.02 & ${ }^{2} 990$ & $4-10$ & 559.3 \\
\hline & & & & $7 / 24 / 2010$ & 11.76 & 598 & $>10$ & 337.9 \\
\hline
\end{tabular}

${ }^{1}$ Annual flood-probability ranges reflect the uncertainty of estimating annual flood-probability discharges. The annual flood probability is calculated using established techniques but then reported in one of the following ranges: greater than 10 percent, 4 to 10 percent, 2 to 4 percent, 1 to 2 percent, 0.2 to 1 percent, and less than 0.2 percent. Unless noted otherwise, annual flood-probability ranges are based on a weighted average of two independent probability estimates. The WIE (weighting of independent estimates) program was used to estimate annual flood probabilities following guidelines in Appendix 8 of Bulletin 17B (Interagency Advisory Committee on Water Data, 1982; Charles Berenbrock and Tim Cohn, U.S. Geological Survey, written commun., 2008). The WIE program uses the variance and estimate of the Bulletin 17B annual streamgage-probability analysis and the variance and estimate of the regional-regression annual probability calculation (Eash, 2001) to compute a weighted probability estimate and variance at a streamgage.

${ }^{2}$ Estimate.

${ }^{3}$ Computed using Bulletin 17B annual streamgage-probability analysis (Interagency Advisory Committee on Water Data, 1982) because regional-regression equations are not applicable.

${ }^{4}$ Annual flood-probability estimates are based on inclusion of additional annual-peak discharges from discontinued downstream streamgage (05417000).

${ }^{5}$ Discharge computed by Prof. F.A. Nagler, University of Iowa (U.S. Geological Survey, 1964).

${ }^{6}$ Flood-probability estimates are based on inclusion of additional annual-peak discharges from active upstream streamgage (05416900).

${ }^{7}$ Annual flood probability not determined because all peak discharges are regulated by upstream dam.

${ }^{8}$ Discharge computed from indirect measurement.

${ }^{9}$ Stage affected by backwater.

${ }^{10}$ Annual flood-probability estimates are based on inclusion of additional annual-peak discharges from discontinued downstream streamgage (05418450).

${ }^{11}$ Prior to Sept. 30, 1972, streamgage at different site and datum.

${ }^{12}$ Peak discharge affected by Lake Delhi Dam failure on July 24.

${ }^{13}$ Annual flood probability not determined because peak discharge affected by Lake Delhi Dam failure. Magnitude of peak discharge is equivalent to that of a natural flood with an annual flood-probability range of 1 to 2 percent. 
are listed in table 4. Although the annual probability is an estimate of the likelihood of a flood discharge of a specific magnitude occurring in any one year, more than one flood discharge with a specific magnitude and annual probability could occur in the same year.

Table 4. Annual flood probability and equivalent flood recurrence interval for selected probabilities.

\begin{tabular}{cc}
\hline $\begin{array}{c}\text { Annual flood probability } \\
\text { (percent) }\end{array}$ & $\begin{array}{c}\text { Recurrence interval } \\
\text { (years) }\end{array}$ \\
\hline 20 & 5 \\
10 & 10 \\
4 & 25 \\
2 & 50 \\
1 & 100 \\
.5 & 200 \\
.2 & 500 \\
\hline
\end{tabular}

\section{Storm Description}

The floods of July 23-26, 2010, were the result of a series of thunderstorms that crossed northeast Iowa during July 22-24. The storms were part of an exceptionally wet period for Iowa from June through September 2010 that followed a wetter than normal first half of the year. A new statewide rainfall record of 10.34 inches was set for the month of June; the old record of 10.33 inches occurred in 1947. Overall, 2010, with an average statewide rainfall of 44.81 inches, was the second wettest year in Iowa in 138 years of record (Hillaker, Iowa Preliminary Annual Weather Summary-2010, http://www.iowaagriculture.gov/ climatology/weatherSummaries/2010/pas2010.pdf; accessed June 28, 2010). Although rainfall during July 2010 was not as great as in June, it was more intense for shorter periods of time, which resulted in greater flooding; the greatest rain event in July occurred on the night of the 22nd when the Oelwein rain gage officially recorded 9.93 inches. An additional 3 to 4 inches of rain fell over the same areas of northeast Iowa the next night. An exceptional rainfall total of 20.33 inches for the month of July at Oelwein far exceeded the old monthly record of 13.30 inches for June 1925 (Hillaker, 2010).

The following rainfall and flood information is from the U.S. Department of Commerce, National Oceanic and Atmospheric Administration, and National Climatic Data Center (2010a) http://www4.ncdc.noaa.gov/cgi-win/wwcgi. dll? wwEvent storms (search terms Iowa, 7/22/2010 to $7 / 24 / 2010$, and flood were entered to obtain a list of 61 flood events; the following quotes were obtained from event numbers (22) Oelwein, (24) Lamont, (38) Backbone State Park, and (46) Arlington).

"Several rounds of thunderstorms [beginning on July 22] developed along a slow moving cold front. These thunderstorms stretched across much of southern Wisconsin into north central and central Iowa. The thunderstorms tracked repeatedly over the same areas dropping several inches of rain across Fayette and Clayton Counties which resulted in flooding problems on July 22nd into the 23rd. Thunderstorms with extremely heavy rain developed [overnight on July 22] along a stationary front and moved from northeast Iowa into northwest Illinois. Some locations measured 5 to 7 inches of rainfall, causing localized flash flooding and pushing numerous creeks out of their banks. The North Fork Maquoketa River through Dubuque County was particularly hard-hit. This round of rainfall further set the stage for the extreme flooding that developed with the next round of storms later that night [July 23]. After about 10 inches of rain fell in the upper Maquoketa River basin, the river surged to record stage levels. Thunderstorms developed along a cold front and swept across northeast Iowa for a second [consecutive] night [July 23]. These storms brought additional heavy rains producing more flood problems on July 23 and 24th."

Hourly rainfall amounts for July 22-24, 2010, for rain gages at Cascade, Dubuque, and Strawberry Point are shown in figure 3 (U.S. Department of Commerce, National Oceanic and Atmospheric Administration, and National Climatic Data Center, 2010b). The graphs provide a general indication of the timing and intensity of the rainfall in the Little Maquoketa River Basin and the upper and central parts of the Maquoketa River Basin. The greatest 1-hour rainfall intensity of 1.5 inches occurred at Strawberry Point ending at 8 a.m. on July 23 (fig. 3C). Data from the three rain gages (fig. 3) indicate that much of the rainfall occurred during a 48-hour period from 6 a.m. on July 22 to 6 a.m. on July 24, and also indicate that Strawberry Point recorded the greatest 24-hour and 48-hour rainfall of 8.2 inches and 11.8 inches, respectively.

An isohyetal map of the areal distribution of rainfall for the 72-hour period beginning at 7:00 a.m. on July 21 and ending at 7:00 a.m., on June 24, 2010, is shown in figure 1; data were provided by Harry Hillaker, State Climatologist, Iowa Department of Agriculture and Land Stewardship (written commun., June 2011). The isohyetal map shows a band of over 12 inches of rainfall in the headwaters of the Maquoketa River Basin upstream of Backbone State Park. Each 24-hour rainfall amount from July 22 to July 24, 2010, for 12 selected rain gages in northeast and east-central Iowa is listed in table 5 (Hillaker, 2010). The 72-hour rainfall total listed in table 5 from July $22-24$ is the time period for which the most significant rainfall could be considered directly contributing to the flooding of July 23-26; although, essentially all rainfall within the Little Maquoketa River and Maquoketa River Basins fell within a 48-hour period (Harry Hillaker, State Climatologist, Iowa Department of Agriculture and Land Stewardship , written commun., June 2011). Seventy-two hour rainfall totals ending on July 24 of 7.33 and 12.23 inches were recorded at Manchester and Strawberry Point, respectively. 


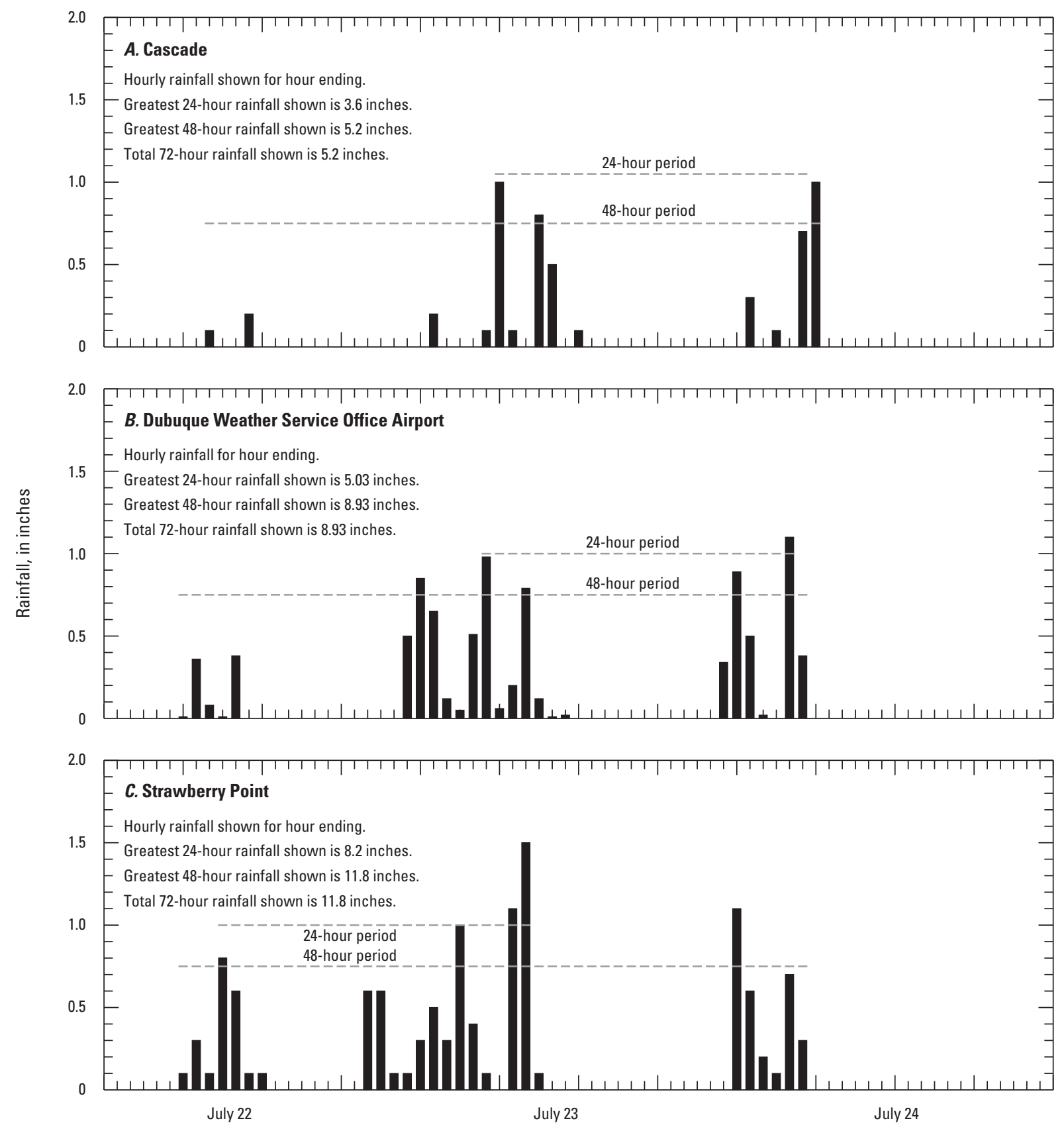

Figure 3. Hourly rainfall for July 22-24, 2010, at three rain gages in the Maquoketa River Basin and vicinity. (Central Daylight Time; U.S. Department of Commerce, National Oceanic and Atmospheric Administration, and National Climatic Data Center, 2010b). 
Table 5. Twenty-four-hour rainfall amounts at selected rain gages in northeast and east-central lowa during July 22-24, 2010.

[T, Trace]

\begin{tabular}{|c|c|c|c|c|c|c|}
\hline \multirow{2}{*}{ Rain gage } & \multirow{2}{*}{$\begin{array}{l}\text { Observation } \\
\text { time }\end{array}$} & \multicolumn{3}{|c|}{ 24-hour rainfall, in inches ${ }^{1}$} & \multirow{2}{*}{$\begin{array}{l}\text { Greatest 48-hour } \\
\text { rainfall total, } \\
\text { in inches }\end{array}$} & \multirow{2}{*}{$\begin{array}{c}\text { 72-hour rainfall } \\
\text { total, } \\
\text { in inches }\end{array}$} \\
\hline & & July 22, 2010 & July 23, 2010 & July 24, 2010 & & \\
\hline Anamosa $1 \mathrm{WNW}$ & 8 a.m. & 0 & 0.95 & 1.50 & 2.45 & 2.45 \\
\hline Bellevue Lock and Dam 12 & 7 a.m. & 0 & 3.85 & 2.45 & 6.30 & 6.30 \\
\hline Cascade & 8 a.m. & .13 & 2.50 & 2.86 & 5.36 & 5.49 \\
\hline Coggon & 7 a.m. & .15 & .25 & 3.08 & 3.33 & 3.48 \\
\hline Dubuque Lock and Dam 11 & 7 a.m. & .15 & 7.18 & 2.10 & 9.28 & 9.43 \\
\hline Dubuque Airport & 1 a.m. & ${ }^{2} 2.84$ & ${ }^{3} 4.59$ & ${ }^{4} 1.5$ & 7.43 & 8.93 \\
\hline Guttenberg Lock and Dam 10 & 7 a.m. & .05 & 3.94 & 2.70 & 6.64 & 6.69 \\
\hline Manchester-2 & 8 a.m. & .52 & 3.89 & 2.92 & 6.81 & 7.33 \\
\hline Maquoketa $4 \mathrm{~W}$ & 8 a.m. & $\mathrm{T}$ & .43 & 2.50 & 2.93 & 2.93 \\
\hline Oelwein $1 \mathrm{E}$ & 8 a.m. & .22 & 9.93 & 3.16 & 13.09 & 13.31 \\
\hline Stanley 4 W & 7 a.m. & .39 & 6.84 & 3.22 & 10.06 & 10.45 \\
\hline Strawberry Point & 8 a.m. & .53 & 8.51 & 3.19 & 11.70 & 12.23 \\
\hline
\end{tabular}

${ }^{1}$ Iowa Climate Review (Hillaker, 2010).

2July 23, 2010.

${ }^{3}$ July 24, 2010.

${ }^{4}$ July 25,2010

The Rainfall Frequency Atlas of the Midwest (Huff and Angel, 1992) provides a table of the mean distribution of theoretical rainfall amounts for climatological divisions in Iowa for selected rain periods and annual probabilities (recurrence intervals). The magnitude and annual probability of theoretical rainfall amounts for selected rain periods (durations) from the table in Huff and Angel (1992) for 2 of the 9 climatological divisions in Iowa are listed in table 6 . Eight of the 12 rain gages listed in table 5 are in the Northeast Iowa Climatological Division and four are located in the East-Central Climatological Division (Hillaker, 2010). A map showing the location of climatological divisions in Iowa is available on page 4 of Huff and Angel (1992) at http:// www.isws.illinois.edu/pubdoc/B/ISWSB-71.pdf, accessed July 6, 2011. The greatest 48-hour rainfalls listed in table 5 exceeded 6.34 inches at seven rain gages all located in the Northeast Climatological Division (Dubuque Lock and Dam 11, Dubuque Airport, Guttenberg Lock and Dam 10, Manchester, Oelwein, Stanley, and Strawberry Point). Annual rainfall probabilities for greatest 48-hour rainfalls for two of these rain gages (Guttenberg and Manchester) are estimated to be 1 to 2 percent, and for the other five of these seven rain gages, annual rainfall probabilities are estimated to be less than 1 percent (table 6).
Table 6. Magnitude and annual probability of theoretical rainfall amounts for selected storm periods in the East-Central and Northeast lowa Climatological Divisions.

[Rainfall amounts from Huff and Angel, (1992)]

\section{East-Central}

\begin{tabular}{ccccc}
\hline \multirow{2}{*}{$\begin{array}{c}\text { Duration } \\
\text { (hours) }\end{array}$} & \multicolumn{4}{c}{ Rainfall (inches) for indicated annual probabilities } \\
\cline { 2 - 5 } & $\mathbf{1 0}$ (percent) & $\mathbf{4}$ (percent) & $\mathbf{2}$ (percent) & $\mathbf{1}$ (percent) \\
\hline 24 & 4.44 & 5.42 & 6.25 & 7.13 \\
48 & 5.05 & 6.02 & 6.87 & 7.83 \\
72 & 5.31 & 6.42 & 7.35 & 8.42 \\
120 & 5.61 & 6.70 & 7.75 & 9.00 \\
240 & 7.12 & 8.25 & 9.27 & 10.35 \\
\hline \multicolumn{5}{c}{ Northeast } \\
\hline Duration & Rainfall (inches) for indicated annual probabilities \\
\cline { 2 - 5 } (hours) & $\mathbf{1 0}$ (percent) & $\mathbf{4}$ (percent) & $\mathbf{2}$ (percent) & $\mathbf{1}$ (percent) \\
\hline 24 & 4.31 & 5.11 & 5.73 & 6.36 \\
48 & 4.69 & 5.62 & 6.34 & 7.09 \\
72 & 5.14 & 6.19 & 7.00 & 7.84 \\
120 & 5.64 & 6.84 & 7.75 & 8.77 \\
240 & 7.07 & 8.29 & 9.20 & 10.19
\end{tabular}


Annual probabilities for two different components of a hydrologic event — rainfall and runoff, respectively — and for various locations in the Little Maquoketa River and Maquoketa River Basins are listed in tables 3 and 6. Similar to the concept of annual flood probability, annual rainfall probability is an estimate of the likelihood of a rainfall of a specific magnitude occurring in any one year, more than one rainfall with a specific magnitude and annual probability could occur in the same year.

\section{Flood Description}

Minor flooding occurred July 23, 2010, in the Little Maquoketa River Basin and major flooding occurred July 23-26, 2010, in the Maquoketa River Basin as a result of the intense rain that fell during July 22-24. The 2010 peak discharges for 11 streamgages in the Little Maquoketa River and Maquoketa River Basins are listed in table 3. Also listed in the table are selected historical peak discharges for the largest-flood years.

Hydrographs of instantaneous discharges measured at continuous-record streamgages on the Maquoketa River and the North Fork Maquoketa River are presented in figure 4 . The period shown is July 22 to July 29,2010 . The streamgages record instantaneous values at 15 -minute time intervals. Also shown on the hydrographs are lines denoting discharge estimates for selected annual flood probabilities. The annual flood-probability range listed in table 3 for the sites is the range between the annual flood-probability discharges that bracket the flood peak discharge. For example, the 2010 peak discharge at streamgage 05416900 Maquoketa River at Manchester, Iowa (fig. 1, site 8) falls between the 1-percent and 0.2-percent annual flood-probability estimates (table 3; fig. 4).

\section{Little Maquoketa River Basin}

The 2010 flood caused minor flooding (annual flood probability greater than 4 percent) in the Little Maquoketa River Basin on July 23, 2010, at four active streamgages located on small drainage-area tributaries (fig.1, sites 1-3 and 6) and at a discontinued mainstem streamgage located in the lower reach of the basin (fig. 1 site 4 ). Of the four tributaries, the streamgage 05414450 Middle Fork Little Maquoketa River near Rickardsville recorded the greatest peak discharge of 8,690 ft $3 / \mathrm{s}$ (table 3). The 2010 flood at this site is estimated to have an annual probability of 4 to 10 percent. At the discontinued streamgage 05414500 Little Maquoketa River near Durango, a peak discharge of $19,000 \mathrm{ft}^{3} / \mathrm{s}$ was estimated on the basis of the stage-discharge rating curve that was in effect during the 2000 water year. The 2010 flood at this site is the sixth largest known flood in the basin since at least 1925, and the annual probability of this peak discharge is estimated to be 4 to 10 percent (table 3 ).

\section{Maquoketa River Basin}

Flooding began on July 23 at streamgages 05416900 Maquoketa River at Manchester (fig. 1, site 8) and 05418400 North Fork Maquoketa River near Fulton (fig. 1, site 15). The peak discharge at both of these streamgages occurred on July 24 (fig. 4); the flood peaked at the Manchester streamgage at $12: 30 \mathrm{p} . \mathrm{m}$. with a discharge of $26,600 \mathrm{ft}^{3} / \mathrm{s}$ and at the Fulton streamgage at 11:00 p.m. with a discharge of $25,000 \mathrm{ft}^{3} / \mathrm{s}$. The 2010 flood is the largest known flood at both the Manchester and Fulton streamgages. The annual flood-probability range of the 2010 flood at the Manchester streamgage is estimated to be 0.2 to 1 percent and at the Fulton streamgage is estimated to be 1 to 2 percent (table 3 ). The peak discharge at streamgage 05418500 Maquoketa River at Maquoketa (fig. 1, site 17) on July 26 at 4:15 a.m. (fig. 4) occurred after the breach of the Lake Delhi Dam on July 24. The dam is located approximately 74 river miles upstream from the Maquoketa streamgage. Because the peak discharge of $46,000 \mathrm{ft}^{3} / \mathrm{s}$ at the Maquoketa streamgage was affected by the dam breach, an annual flood probability was not determined for the 2010 flood at this site (table 3). The magnitude of the 2010 peak discharge at the Maquoketa streamgage is equivalent to that of a natural flood with an annual flood-probability range of 1 to 2 percent. Peak discharges at the three streamgages shown in figure 4 were determined from rating curves that were verified by discharge measurements made near the time of occurrence of the respective peaks.

For informational purposes, also shown on two of the hydrographs, are the discharges corresponding to the National Weather Service (NWS) designated flood stage (fig.4). The flood stages represent "an established gage height for a given location at which a rise in water surface level begins to impact lives, property, or commerce" (http://www.weather. gov/directives/sym/pd01009050curr.pdf, accessed September 13, 2011). The discharges corresponding to the NWS flood stages were determined from the respective USGS stage-discharge rating curves in use at the time of the flood. At streamgage 05416900 Maquoketa River at Manchester, the NWS flood stage is $14.0 \mathrm{ft}$ (discharge 5,550 $\mathrm{ft}^{3} / \mathrm{s}$ ), which is the stage that water affects West Main Street and residences on the south side of town (at http://water.weather.gov/ahps2/hydrograph.php? wfo $=$ dvn\&gage $=$ mchi $4 \&$ view $=1,1,1,1,1,1,1,1$, , accessed September 13, 2011). The streamgage Maquoketa River at Manchester was above flood stage during July 23-25, and the peak stage of $24.48 \mathrm{ft}$ (table 3 ) exceeded the flood stage by $10.48 \mathrm{ft}$. At streamgage 05418500 Maquoketa River near Maquoketa, the NWS flood stage is $24.0 \mathrm{ft}$ (discharge $13,300 \mathrm{ft}^{3} / \mathrm{s}$ ), which is the stage that water affects agricultural land in the Maquoketa area and several storm sewers in town (at http://water.weather.gov/ahps2/hydrograph.php? wfo $=d v$ n\&gage $=$ maqi4\&view $=1,1,1,1,1,1,1,1$ ", accessed September 13, 2011). The streamgage Maquoketa River near Maquoketa was above flood stage during July 24-27, and the peak stage of $35.26 \mathrm{ft}$ (table 3) exceeded the flood stage by $11.26 \mathrm{ft}$. 

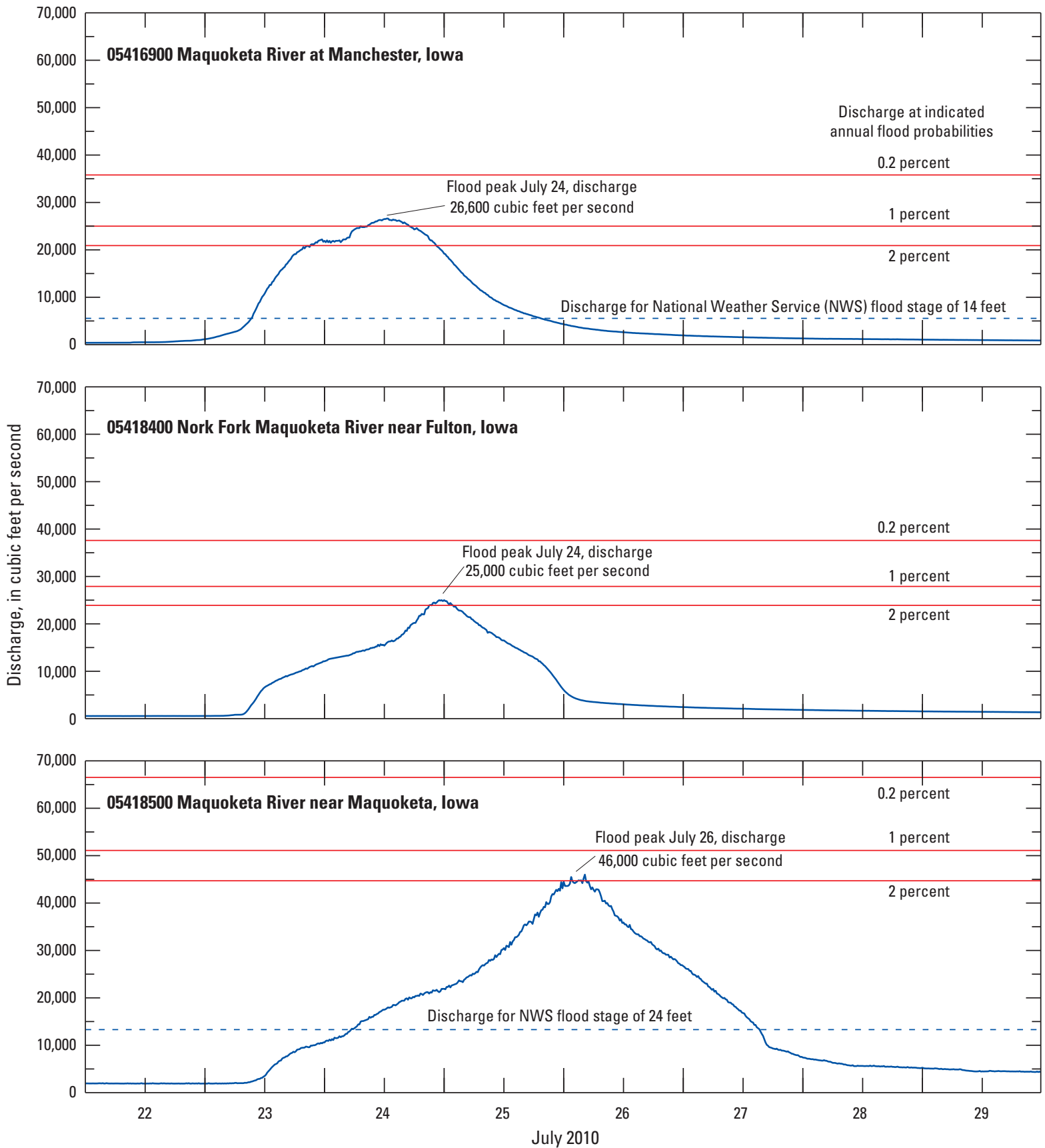

Figure 4. Discharge hydrographs for streamgages on the Maquoketa River and the North Fork Maquoketa River, July 22-29, 2010. 
The NWS has not determined a flood stage at streamgage 05418400 North Fork Maquoketa River near Fulton.

\section{Chronology of Flood Impacts}

The following flood description information was obtained from newspaper articles posted online by the Des Moines Register (Finney, July 24, 2010), the Gazette (David DeWitte, July 26, 2010a, July 26, 2010b), the Associated Press (July 25, 2010), and the Telegraph Herald (Andy Piper and Michael Schmidt, July 24, 2010; Eileen Mozinski Schmidt, July 26, 2010); and from on-line sources obtained from the U.S. Department of Commerce, National Oceanic and Atmospheric Administration, and National Climatic Data Center (2010a) and from KCRG-TV (Dave DeWitte, July 26, 2010c).

In New Vienna, near the headwaters of the North Fork Maquoketa River, Fire Chief Henry Westhoff, reported the river crested at 5:30 a.m. on July 23, 2010, about $2 \mathrm{ft}$ higher than ever before, and that the river returned to within its banks at about 11 a.m. Further downstream in Dyersville, Candy Cane and West Side parks were inundated with several feet of water where the North Fork Maquoketa River, Bear Creek, and Hewitt Creek converge on the southwest side of the city. Tim Pins, Dyersville Fire Chief, reported the flood water rose very quickly, noting that the North Fork Maquoketa River topped its banks at about 3 a.m. and crested at $14 \mathrm{ft}$ at 9:20 a.m. on July 23. Residents on the west side of Third Avenue in Dyersville suffered flooded basements. Also on the morning of July 23, in the upper part of the Maquoketa River Basin, flash flooding occurred in Lamont where city crews had to sandbag the lift pump station due to rising flood waters. In Manchester, the Maquoketa River was reported to have been rising at about 1-foot per hour; the Delaware County Emergency Management and the City of Manchester decided to close West Main Street between Franklin Avenue and Legions Street around 11:30 a.m. Jack Klaus, Delaware County Emergency Management noted the closing of West Main Street usually occurs when the river stage reaches $17 \mathrm{ft}$. Several Manchester streets and county roads were closed due to dangerous conditions. Numerous homes in Manchester and several buildings in the downtown area were flooded, and utilities were shut off to parts of the city that were considered to be at risk of flooding. Four to five ft of water filled some homes and businesses; many basements filled with water and several basement walls were reported to have collapsed. A man in town escaped a life-threatening situation when a sinkhole developed in a parking lot and the skidloader he was driving collapsed into the raging Maquoketa River beneath the parking lot. Downstream of Manchester, some campers and residents on Lake Delhi had to be rescued by boat overnight on July 23. Numerous properties were damaged along the Maquoketa River, including about 500 homes and the marina bordering Lake Delhi. Also, overnight on July 23, the main street in Arlington, in southeastern Fayette County, was reported impassable due to rising waters.
On July 24, water from the Maquoketa River began flowing over the Delhi Dam at 10:30 a.m.; by 1:00 p.m., a 30-ft section of road, rock, and earthen embankment broke loose and a torrent of river water raged through, destroying at least five homes and threatening the town of Hopkinton downstream. Boats, propane tanks, and a construction barge crashed through the breach and tumbled downstream. Downstream of the dam, County Road D47 was closed as water from the dam submerged the bridge near Hopkinton. Craig Wilson, Hopkinton Fire Chief, ordered half the town to evacuate; he began allowing residents to return to their homes in the afternoon of July 24. Aircraft from the Iowa State Patrol monitored the surge of water from the dam breach and reported that the surge slowed upstream of Hopkinton where the flood plain attenuated the flood waters. On the southeast side of Hopkinton, about five homes were flooded. Police Chief Britt Smith reported that downstream along the Maquoketa River in Monticello about 50 homes, including two mobile home parks, were evacuated. U.S. Business Highway 151/Main Street in Monticello was one of about a dozen roads closed by the weekend flooding of the Maquoketa and Wapsipinicon Rivers in Jones County, reported Mike McClain, Jones County Engineer, the road closures also included County Road E17 and State Highway 136 north of Onslow. Minor damage was reported for a stretch of State Highway 38. Downstream of Monticello near Scotch Grove, the Maquoketa River flood washed away the privately owned Corbett's Mill Bridge, a historic bowstring (or tied-arch bridge) built in 1871. Further downstream along the Maquoketa River in the city of Maquoketa, emergency workers and area residents teamed up on July 25 to build a wall of sandbags at the intersection of North Main Street and Pershing Road to prevent flooding of the city's wastewater plant, electric plant, and water treatment facility, reported Al Muhlhausen, Assistant Fire Chief for the City of Maquoketa. The dam breach at Lake Delhi flooded agricultural land downstream of the dam. On July, 26, 2010, Keith Krause, Delaware County District Conservationist, Natural Resources Conservation Service (NRCS), estimated that 2,000 acres of crop land and 2,000 acres of pasture were inundated along the Maquoketa River; Virgil Schmitt, extension field agronomist for Iowa State University, said it was too late in the year for farmers to replant lost crops.

\section{Breach of Lake Delhi Dam}

Lake Delhi Dam was built between 1922 and 1929 by the Interstate Power Company for hydroelectric power generation. In 1974, the Lake Delhi Recreation Association bought the dam and has owned it since then. Jon Garton, Iowa Department of Natural Resources dam safety engineer, reported that Lake Delhi Dam was used to maintain water levels in the upper and lower parts of the lake for recreational purposes and it was not used for flood control downstream of Lake Delhi (Lynch, The Gazette, July 26, 2010). Detailed information on the breach of Lake Delhi Dam is available from the Report on 
Breach of Delhi Dam (Independent Panel of Engineers, 2010). The crest of Lake Delhi Dam is at elevation $904.8 \mathrm{ft}$ and the spillway crest is at $879.8 \mathrm{ft}$ NGVD 29 (the peak-flood elevation at the dam determined by the USGS was $905.55 \mathrm{ft}$ ). The cause of the dam breach was internal erosion in the embankment coupled with overtopping flow which resulted in an estimated peak breach outflow of about $69,000 \mathrm{ft}^{3} / \mathrm{s}$ (Independent Panel of Engineers, 2010).

\section{Flood Profile}

To develop profiles of the 2010 floods for the Little Maquoketa, North Fork Little Maquoketa, Maquoketa, and North Fork Maquoketa Rivers, the USGS measured highwater marks (HWMs) at 46 locations. The HWMs that were used in the profiles were measured at all Federal and State Highway bridges, at USGS streamgages, at selected county and local bridges, and at selected dams. The HWMs at bridges were located immediately downstream from a bridge and one bridge-length upstream from the bridge. The distances between most of the profile points are less than about 12 mi (fig. 1). The distance between Ebys Mill Road and U.S. Highway 151 on the Maquoketa River is about 13.8 $\mathrm{mi}$, and between 21st Avenue and 1st Avenue on the North Fork Maquoketa River is about $18.3 \mathrm{mi}$. River miles were determined using a geographic information system (GIS) to measure the distance along each river reach from its mouth using USGS 1:24,000-scale topographic-map data.

The HWMs were surveyed to bench marks (see appendix) at bridges, dams, and intermediate sites within one week of the flood peak, and were later referenced to the NGVD 29 by differential leveling or differential positioning using a global positioning system (GPS). In addition, bridge-deck, low-bridge-chord, and reference-point elevations were measured with respect to the bench marks. The elevations for the bridge deck and low-bridge chord were generally measured on the lowest end of the bridge. The reference points were established so that low-flow water-surface elevations could be measured by using a weight suspended on a measuring tape. Low-flow water-surface elevations were obtained during November 2010 to indicate the range in stage along the river and to define the low-water slope.

The HWMs are profiled in figures 5-18 and listed in tables 7-9. The profile lines connecting the HWMs in the figures approximate the flood elevation between marks. The lines do not account for any intermediate features that could affect flood elevation such as channel morphology or bridges and dams where HWMs were not measured. Primary highways referenced in the report are shown in figure 1; secondary roads are not shown in the figure.

The July 23, 2010, flood along the Little Maquoketa and North Fork Little Maquoketa Rivers is profiled from U.S. Highway 52 near Dubuque upstream to County Road Y21 near Rickardsville (fig. 1). The 19-mi river reach is shown in figure 1, and the five stream sites where HWMs were measured are listed in table 7 .

Table 7. Locations and elevations of high-water marks used in the Little Maquoketa River and North Fork Little Maquoketa River flood profiles of July 23, 2010.

[HWM, high-water mark; NGVD 29, National Geodetic Vertical Datum of 1929; USGS, U.S. Geological Survey]

\begin{tabular}{|c|c|c|c|}
\hline $\begin{array}{l}\text { Distance } \\
\text { from mouth } \\
\text { (river miles) }\end{array}$ & Location & $\begin{array}{c}\text { Downstream } \\
\text { HWM } \\
\text { (feet above } \\
\text { NGVD 29) }\end{array}$ & $\begin{array}{l}\text { Upstream } \\
\text { HWM } \\
\text { (feet above } \\
\text { NGVD 29) }\end{array}$ \\
\hline 4.13 & $\begin{array}{l}\text { U.S. Highway 52, south of } \\
\text { Sageville }\end{array}$ & 621.82 & 621.98 \\
\hline 6.48 & $\begin{array}{l}\text { Clay Hill Road, east of } \\
\text { Durango, discontin- } \\
\text { ued USGS streamgage } \\
05414500\end{array}$ & 632.79 & 635.63 \\
\hline 10.62 & $\begin{array}{l}\text { U.S. Highway 52, west of } \\
\text { Durango }\end{array}$ & 662.42 & 663.43 \\
\hline 16.40 & $\begin{array}{c}\text { South Mound Road, east } \\
\text { of Rickardsville, USGS } \\
\text { streamgage } 05414450\end{array}$ & 755.81 & 757.57 \\
\hline 23.03 & $\begin{array}{l}\text { County Road Y21/James } \\
\text { Road, northwest of Rick- } \\
\text { ardsville }\end{array}$ & 849.26 & 850.54 \\
\hline
\end{tabular}

The July 23-26, 2010, flood along the Maquoketa River is profiled from U.S. Highway 52 near Green Island upstream to State Highway 187 near Arlington (fig. 1). The 142-mi river reach is shown in figure 1 , and the 28 stream sites where HWMs were measured are listed in table 8. A flood profile measured in June 2002 and a low-water profile measured in December 2002 (Eash, 2005) are shown in figures 8-12 for the Maquoketa River from U.S. Highway 52 near Green Island upstream to U.S. Highway 20 south of Manchester. A flood profile measured in May 2004 and a low-water profile measured in November 2004 (Eash, 2006) also are shown in figures 8, and 12-13, for the Maquoketa River from County Road D47 near Hopkinton upstream to State Highway 187 near Arlington.

The July 23-24, 2010, flood along the North Fork Maquoketa River is profiled from Rockdale Road near Maquoketa upstream to U.S. Highway 52 near Luxemburg (fig. 1). The 90-mi river reach is shown in figure 1, and the 13 stream sites where HWMs were measured are listed in table 9. A flood profile measured in June 2002 and a low-water profile measured in December 2002 (Eash, 2005) are shown in figures 14-18 for the North Fork Maquoketa River along the entire North Maquoketa River reach profiled for the 2010 flood with the exception of the reach between State Highway 136 at New Vienna and U.S. Highway 52 near Luxemburg. 
Table 8. Locations and elevations of high-water marks used in the Maquoketa River flood profile of July 23-26, 2010.

[HWM, high-water mark; NGVD 29, National Geodetic Vertical Datum of 1929; USGS, U.S. Geological Survey; ND, not determined]

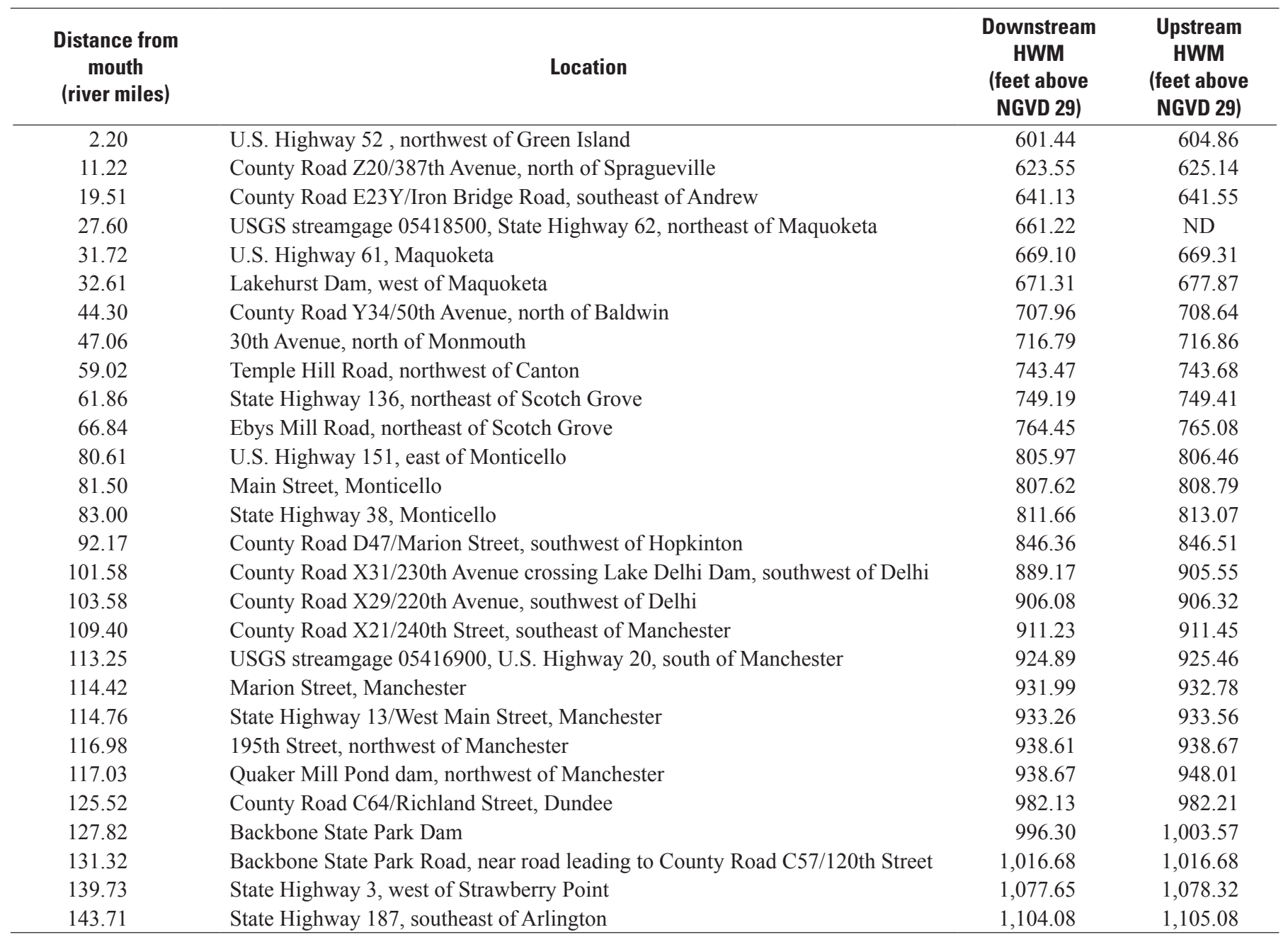

Table 9. Locations and elevations of high-water marks used in the North Fork Maquoketa River flood profile of July 23-24, 2010.

[HWM, high-water mark; NGVD 29, National Geodetic Vertical Datum of 1929; ND, not determined; USGS, U.S. Geological Survey; NA, not applicable]

\begin{tabular}{|c|c|c|c|}
\hline $\begin{array}{c}\text { Distance from } \\
\text { mouth } \\
\text { (river miles) }\end{array}$ & Location & $\begin{array}{c}\text { Downstream } \\
\text { HWM } \\
\text { (feet above } \\
\text { NGVD 29) }\end{array}$ & $\begin{array}{c}\text { Upstream } \\
\text { HWM } \\
\text { (feet above } \\
\text { NGVD 29) }\end{array}$ \\
\hline 8.24 & U.S. Highway 61, south of Fulton, discontinued USGS streamgage 05418450 & 686.88 & ND \\
\hline 12.37 & USGS streamgage 05418400 , County Road E17/150th Street, northwest of Fulton & 701.44 & 702.04 \\
\hline 44.58 & 1st Avenue West, Cascade & 814.82 & 818.87 \\
\hline 45.29 & U.S. Highway 151 , north of Cascade & 820.97 & 822.03 \\
\hline 47.50 & State Highway 136, northwest of Cascade & 830.70 & 830.82 \\
\hline 57.74 & Along 305th Street, south of Worthington & 874.20 & NA \\
\hline 63.90 & County Road D35/272nd Street, west of Worthington & 897.61 & 897.94 \\
\hline
\end{tabular}




\section{Summary}

Information on flood peaks and water-surface-elevation profiles is needed for the planning and safe design of bridges and other structures along rivers and streams and also for effective management of flood plains. Data for major floods are needed to compute flood-peak discharges and calibrate water-surface-elevation models. This report was prepared in cooperation with the Iowa Department of Transportation and the Iowa Highway Research Board.

As a result of intense periods of rainfall July 22-24, 2010, minor flooding occurred in the Little Maquoketa River Basin and major flooding occurred in the Maquoketa River Basin during July 23-26. Seventytwo-hour rainfall amounts recorded at Manchester and Strawberry Point on July 24 were 7.33 and 12.23 inches, respectively. The majority of the rainfall occurred during a 48-hour period. Within the Little Maquoketa River Basin, a peak-discharge estimate of 19,000 $\mathrm{ft}^{3} / \mathrm{s}$ (annual floodprobability estimate of 4 to 10 percent) at the discontinued streamgage 05414500 Little Maquoketa River near Durango, Iowa on July 23 is the sixth largest flood on record. Within the Maquoketa River Basin, peak discharges of $26,600 \mathrm{ft}^{3} / \mathrm{s}$ (annual flood-probability estimate of 0.2 to 1 percent) at the 05416900 Maquoketa River at Manchester, Iowa streamgage on July 24, and of 25,000 ft $3 / \mathrm{s}$ (annual flood-probability estimate of 1 to 2 percent) at the 05418400 North Fork Maquoketa River near Fulton, Iowa streamgage also on July 24 are the largest floods on record for these sites. A peak discharge of $46,000 \mathrm{ft}^{3} / \mathrm{s}$ on July 26 at the 05418500 Maquoketa River near Maquoketa, Iowa streamgage is the third highest on record. The July 24 breach of Lake Delhi Dam, located 74 river miles upstream of the Maquoketa River near Maquoketa streamgage, affected the flood peak at the Maquoketa streamgage.

\section{References Cited}

Associated Press, 2010, Flood breaches Lake Delhi Dam: Telegraph Herald, July 25, 2010, accessed June 2, 2011, at http://www.thonline.com/news/feature_stories/ article_4c5dde8f-d446-5669-987e-c7f236042e2d.html.

DeWitte, David, 2010a, Flood damage to Business 151 in Monticello believed minimal: The Gazette, July 26, 2010, accessed June 3, 2011, at http://thegazette.com/2010/07/26/ flood-damage-to-business-151-in-monticello-believedminimal/.

DeWitte, David, 2010b, 6,000 acres of crop land flooded in Jones, Delaware counties: The Gazette, July 26, 2010, accessed June 3, 2011, at http://thegazette. com/2010/07/26/6000-acres-of-cropland-flooded-in-jonesdelaware-counties/.
DeWitte, Dave, 2010c, Floods claim historic Jones County bridge: KCRG-TV, July 26, 2010, accessed June 28, 2010, at http://www.kcrg.com/news/local/Floods-Claim-HistoricJones-County-Bridge-99276849.html.

Eash, D.A., 2001, Techniques for estimating flood-frequency discharges for streams in Iowa: U.S. Geological Survey Water-Resources Investigations Report 00-4233, 88 p. (Also available at http://pubs.er.usgs.gov/usgspubs/wri/ wri004233.)

Eash, D.A., 2005, Flood of June 4-5, 2002, in the Maquoketa River Basin, east-central Iowa: U.S. Geological Survey Open-File Report 2004-1250, 29 p. (Also available at http://pubs.usgs.gov/of/2004/1250/pdf/ofr20041250.pdf.)

Eash, D.A., 2006, Flood of May 23, 2004, in the Turkey and Maquoketa River Basins, northeast Iowa: U.S. Geological Survey Open-File Report 2006-1067, 35 p. (Also available at: http://pubs.usgs.gov/of/2006/1067/.)

Federal Emergency Management Agency, 2010, Federal Register Notice, accessed July 6, 2011, at http://www.fema.gov/ news/event.fema? id=13099; http://www.fema.gov/pdf/news/ pda/1930.pdf.

Finney, Daniel, 2010, Iowa flood worries flow southeast to Hopkinton, Monticello: Des Moines Register, July 24, 2010, accessed June 2, 2011, at http://blogs.desmoinesregister. com/dmr/index.php/2010/07/24/catastrophic-release-ofwater-poors-over-failed-lake-delhi-dam/.

Heinitz, A.J., 1973, Flood of August 2, 1972, in the Little Maquoketa River Basin, Dubuque County, Iowa: U.S. Geological Survey Open-File Report 73-107, 28 p.

Hillaker, H.J., 2010, Iowa climate review, v. 24, no. 7, July 2010: Iowa Department of Agriculture and Land Stewardship, Des Moines, Iowa, $21 \mathrm{p}$.

Horick, P.J., and Soenksen, P.J., 1989, Water resources of northeast Iowa: Iowa Department of Natural Resources Water Atlas 8, 133 p., accessed April 8, 2011, at http://www. igsb.uiowa.edu/Mapping/abstract/wa8.htm.

Huff, F.A., and Angel, J.R., 1992, Rainfall frequency atlas of the Midwest: Champaign, Illinois State Water Survey, Bulletin 71, 141 p., accessed November 16, 2011, at http:// www.isws.illinois.edu/pubdoc/B/ISWSB-71.pdf.

Independent Panel of Engineers, 2010, Report on the breach of Delhi Dam: 97 p. and appendices: accessed November 16, 2011, at http://www.iowadnr.gov/InsideDNR/ RegulatoryLand/DamSafety.aspx.

Interagency Advisory Committee on Water Data, 1982, Guidelines for determining flood flow frequency: Reston, Va., Hydrology Subcommittee Bulletin 17B, 28 p. and appendixes. (Also available at http://water.usgs.gov/osw/ bulletin17b/bulletin_17B.html.) 
Iowa Conservation Commission, 1979, Iowa's low-head damstheir past, present, and future roles: Des Moines, Iowa, Iowa State Water Resources Research Institute Special Report no. 96,312 p.

Iowa Natural Resources Council, 1958, An inventory of water resources and water problems, northeastern Iowa river basins: Des Moines, Iowa, Iowa Natural Resources Council Bulletin no. 7, 74 p.

Larimer, O.J., 1957, Drainage areas of Iowa streams: Iowa Highway Research Board Bulletin no. 7 (reprinted 1974), 439 p, accessed November 16, 2011, at http://www.iowadot. gov/operationsresearch/reports/reports_pdf/hr_and_tr/ reports/HR-29\%20Final\%20Report\%201957.pdf.

Lynch, James, Q., 2010, Replacing road over Lake Delhi Dam could take two years, cost millions: The Gazette, July 26, 2010, accessed June 3, 2011, at http://thegazette. com/2010/07/26/mother-natures-in-control-at-lake-delhi/.

Oschwald, W.R., Riecken, F.F., Dideriksen, R.I., Scholtes, W.H., and Schaller, F.W., 1965, Principal soils of Iowa: Ames, Iowa, Iowa State University, Department of Agronomy, Special Report no. 42, 77 p.

Piper, Andy, and Schmidt, Michael, 2010, Culver issues disaster declaration for county: Telegraph Herald, July 24, 2010, accessed June 3, 2011, at http://www.thonline.com/ news/feature_stories/article_44f7a348-f53c-564b-aea4054724a52f89. html.
Prior, J.C., 1991, Landforms of Iowa: Iowa City, University of Iowa Press, 154 p.

Prior, J.C., Kohrt, C.J., and Quade, D.J., 2009, The Landform Regions of Iowa, vector digital data, Iowa Geological Survey, Iowa Department of Natural Resources, Iowa City, Iowa, accessed July 2011, at ftp://ftp.igsb.uiowa.edu/gis library/ia_state/geologic/landform/landform_regions.zip.

Schmidt, Eileen Mozinski, 2010, A race against the clock: Telegraph Herald, July 26, 2010, accessed June 3, 2011, at http://www.thonline.com/news/feature_stories/article_ ec7380ff-6cal-5ea6-ab3b-eac91b6d0f0a.html.

U.S. Department of Commerce, National Oceanic and Atmospheric Administration, and National Climatic Data Center, 2010a, National Climatic Data Center Storm Events, accessed June 27, 2011, http://www4.ncdc.noaa.gov/ cgi-win/wwcgi.dll?wwEvent storms (search terms: Iowa, $7 / 22 / 2010$ to $7 / 24 / 2010$, flood).

U.S. Department of Commerce, National Oceanic and Atmospheric Administration, and National Climatic Data Center, 2010b, Hourly precipitation data, Iowa, July 2010: Asheville, N.C., Monthly Summaries, v. 60, no. 7, 19 p.

U.S. Geological Survey, 1964, Compilation of records of surface waters of the United States, October 1950 to September 1960, part 5, Hudson Bay and upper Mississippi River Basins: U.S. Geological Survey Water-Supply Paper 1728, $576 \mathrm{p}$. 
Figures 5-18 


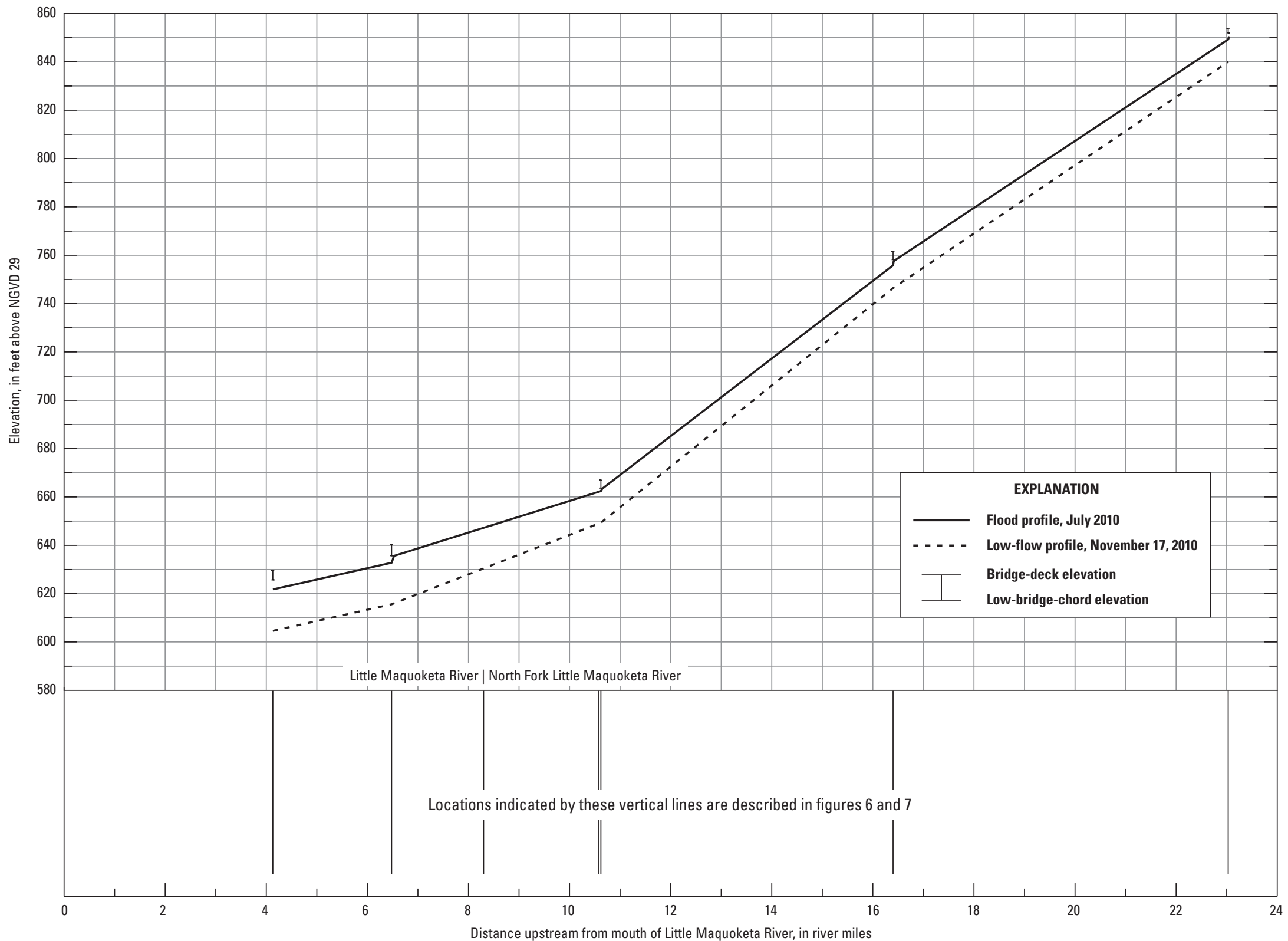

Figure 5. Profile of the July 23, 2010, flood for the Little Maquoketa River and the North Fork Little Maquoketa River, river miles 4 to 23. 


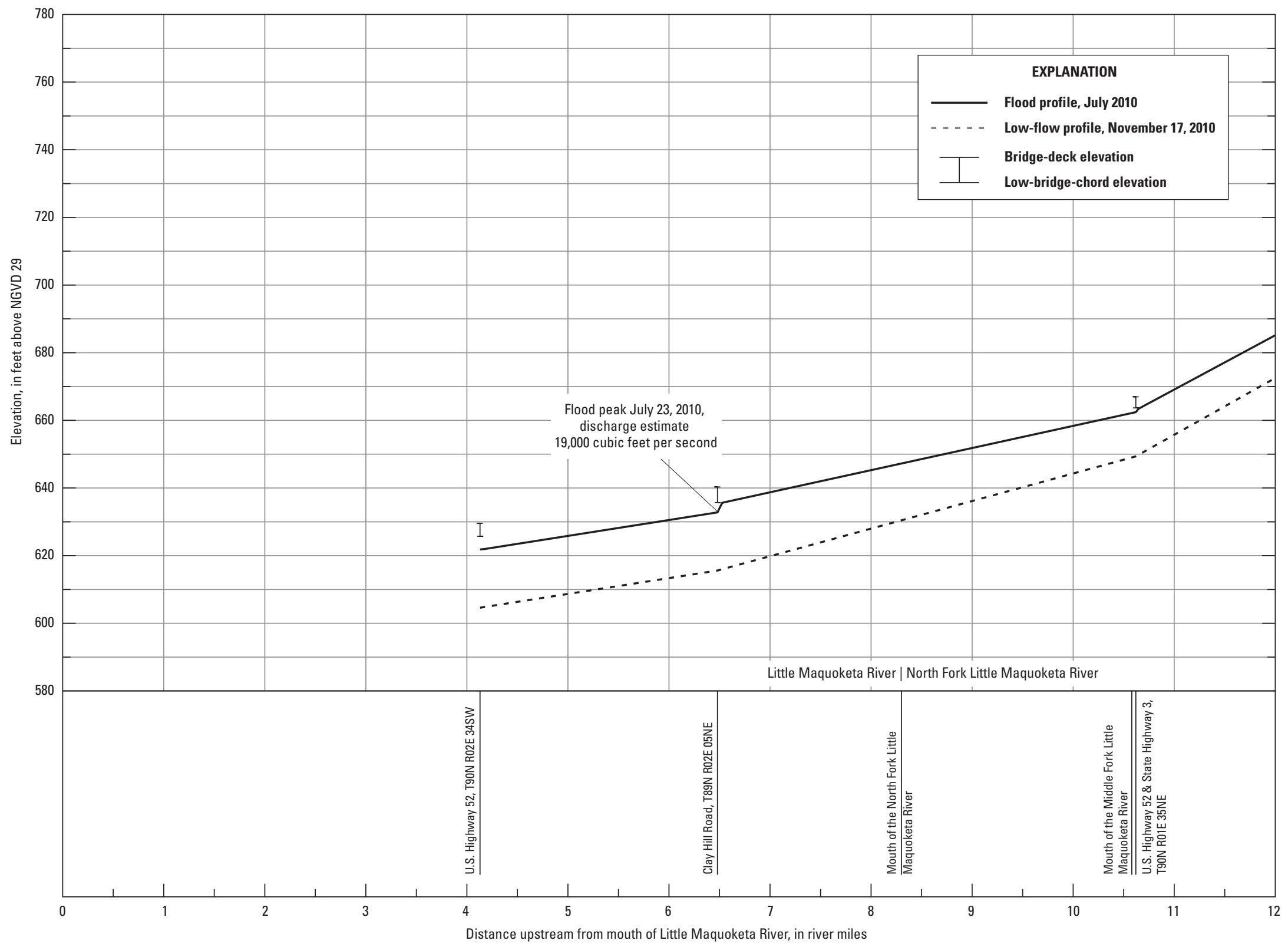

Figure 6. Profile of the July 23, 2010, flood for the Little Maquoketa River and the North Fork Little Maquoketa River, river miles 4 to 12. 


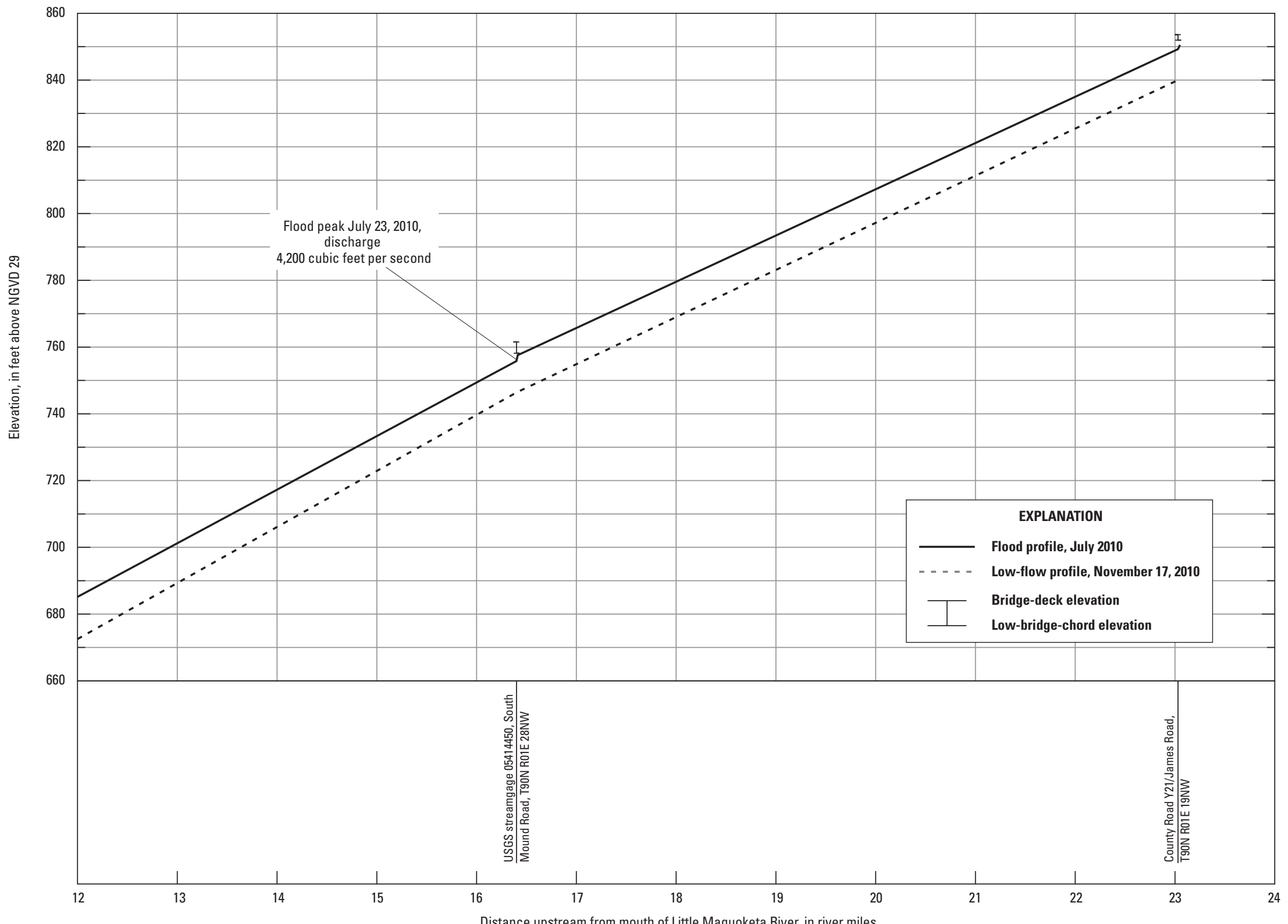

Figure 7. Profile of the July 23, 2010, flood for the North Fork Little Maquoketa River, river miles 12 to 23. 


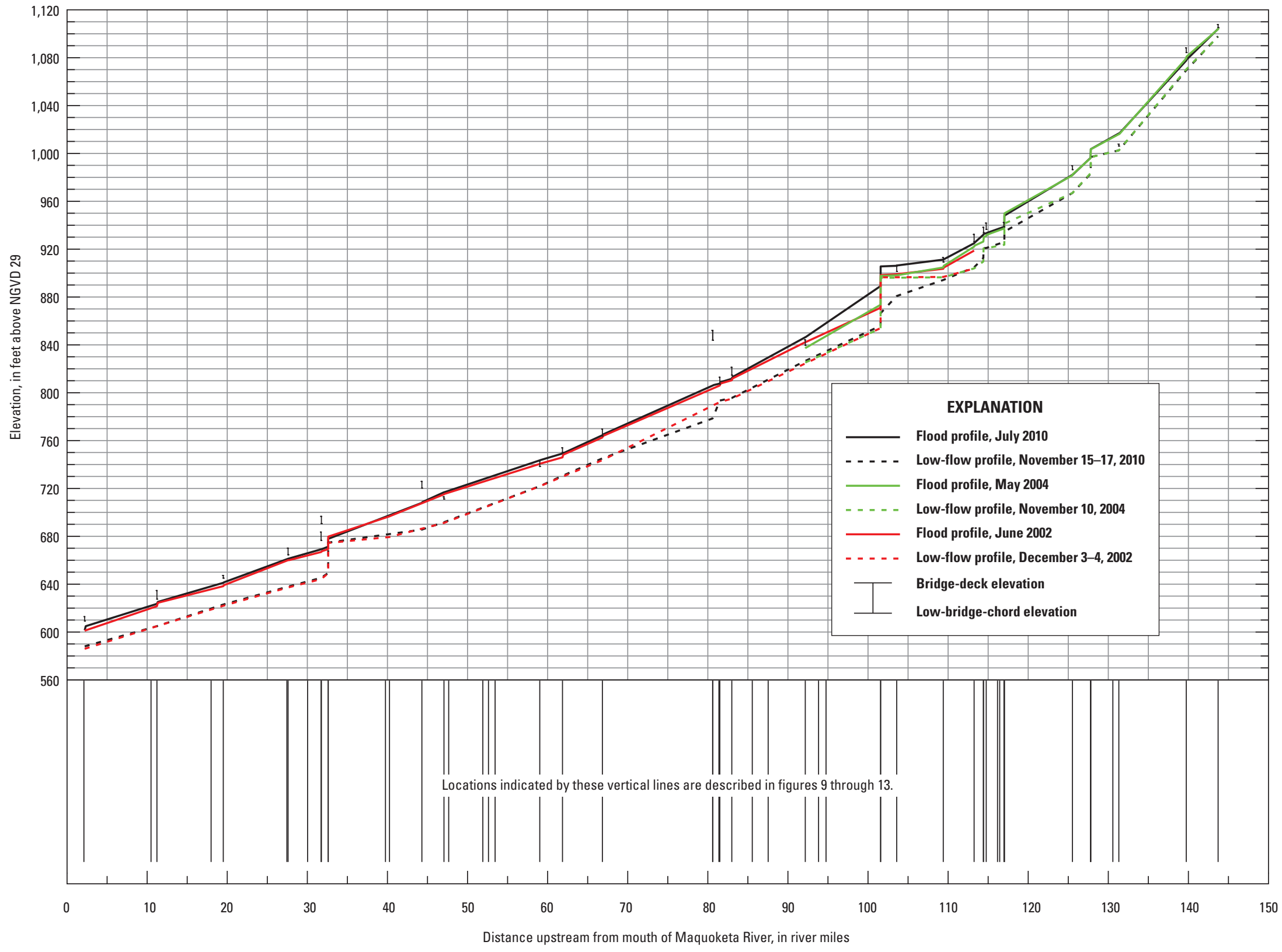

Figure 8. Profile of the July 23-26, 2010, flood for the Maquoketa River, river miles 2 to 144. 


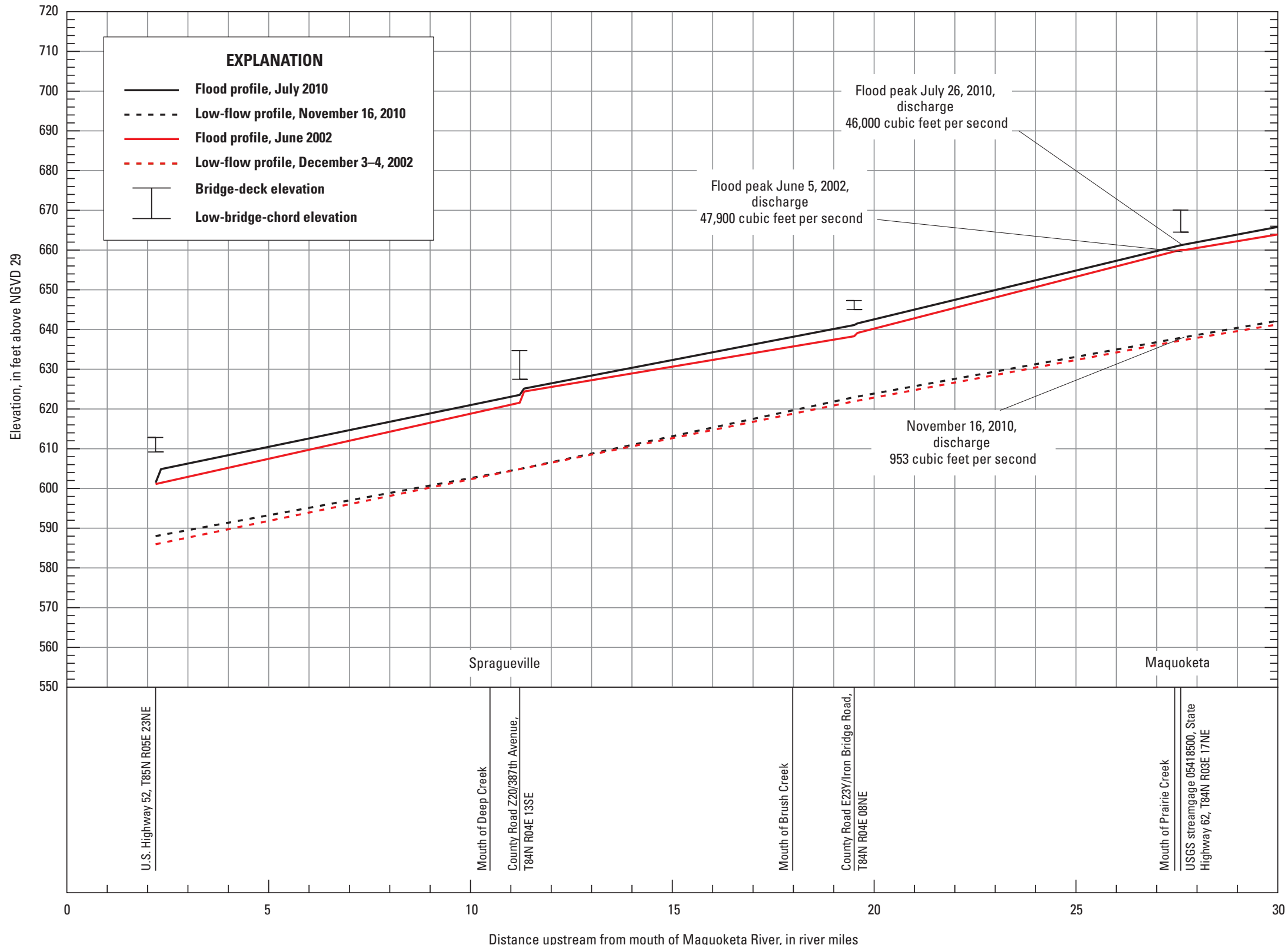

Figure 9. Profile of the July 23-26, 2010, flood for the Maquoketa River, river miles 2 to 30. 


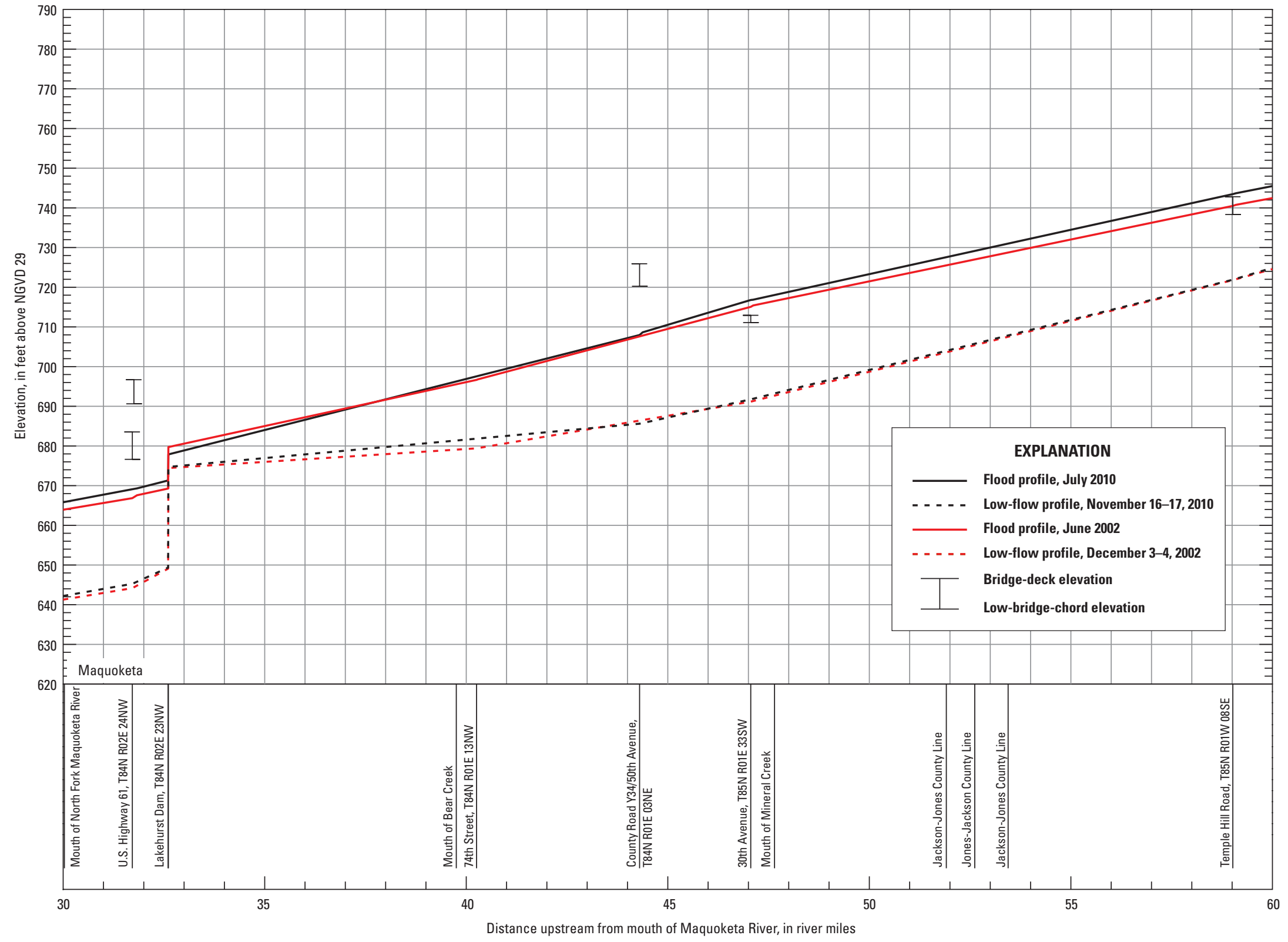

Figure 10. Profile of the July 23-26, 2010, flood for the Maquoketa River, river miles 30 to 60. 


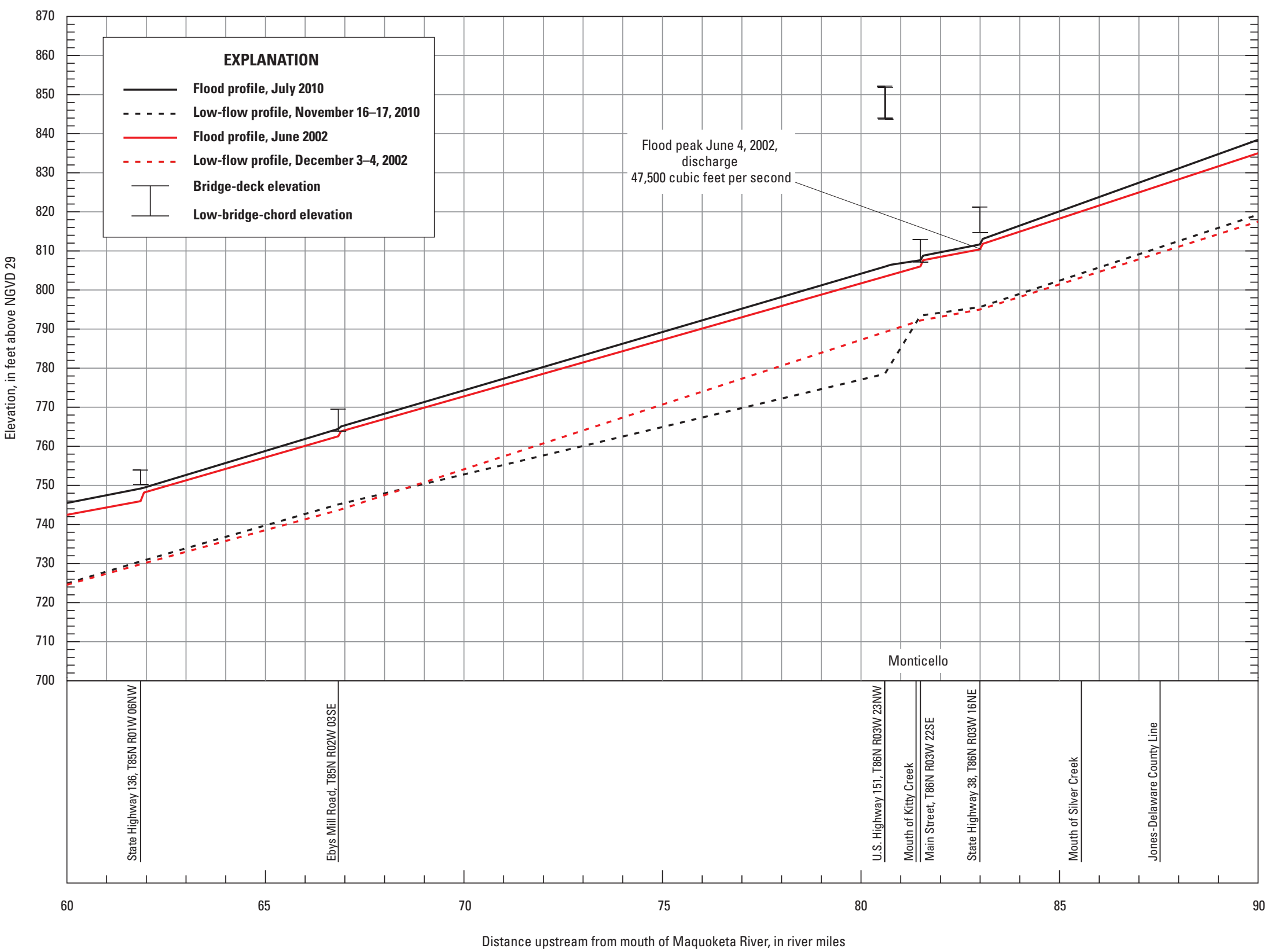

Figure 11. Profile of the July 23-26, 2010, flood for the Maquoketa River, river miles 60 to 90. 


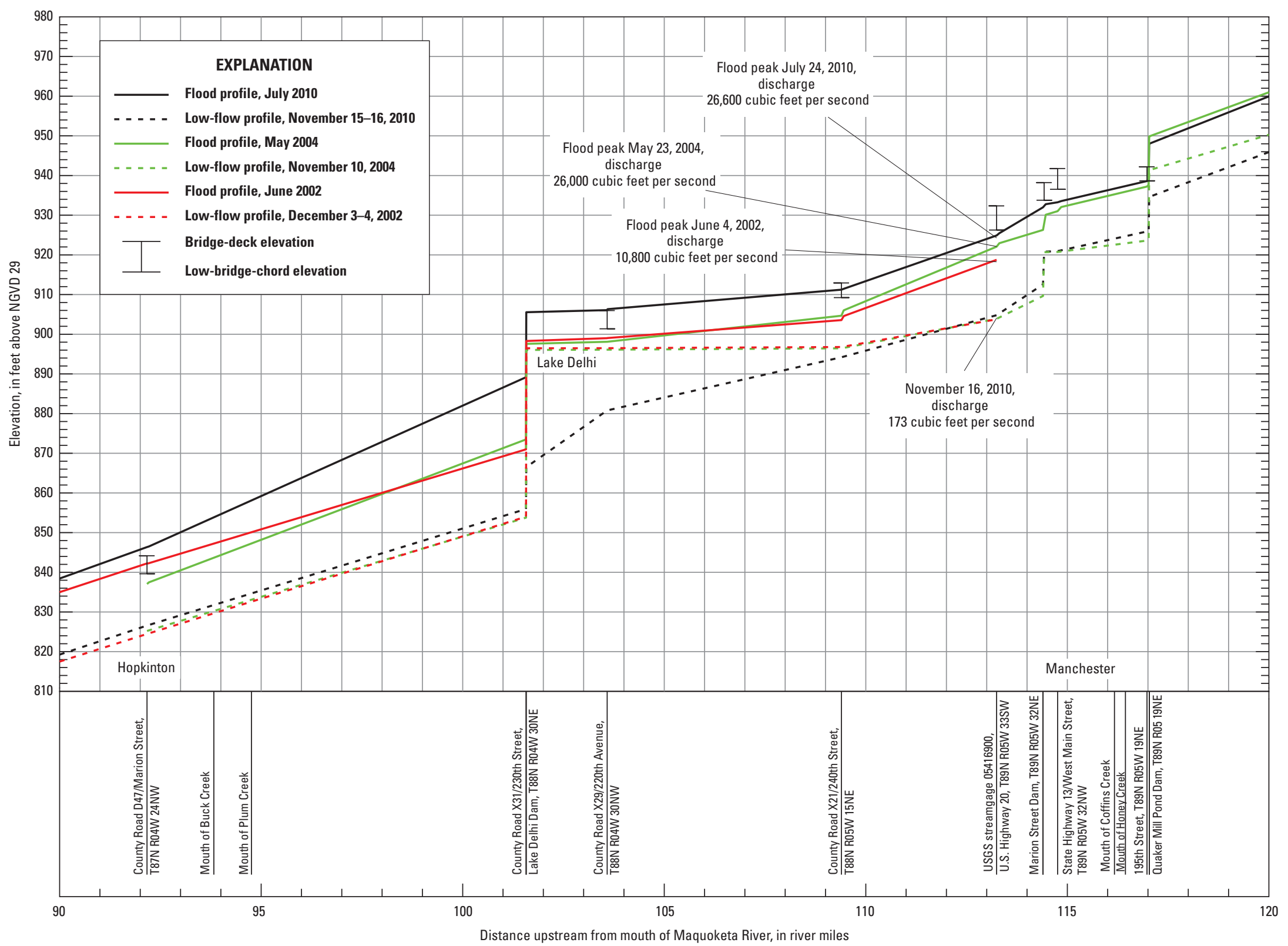

Figure 12. Profile of the July 23-26, 2010, flood for the Maquoketa River, river miles 90 to 120 . 


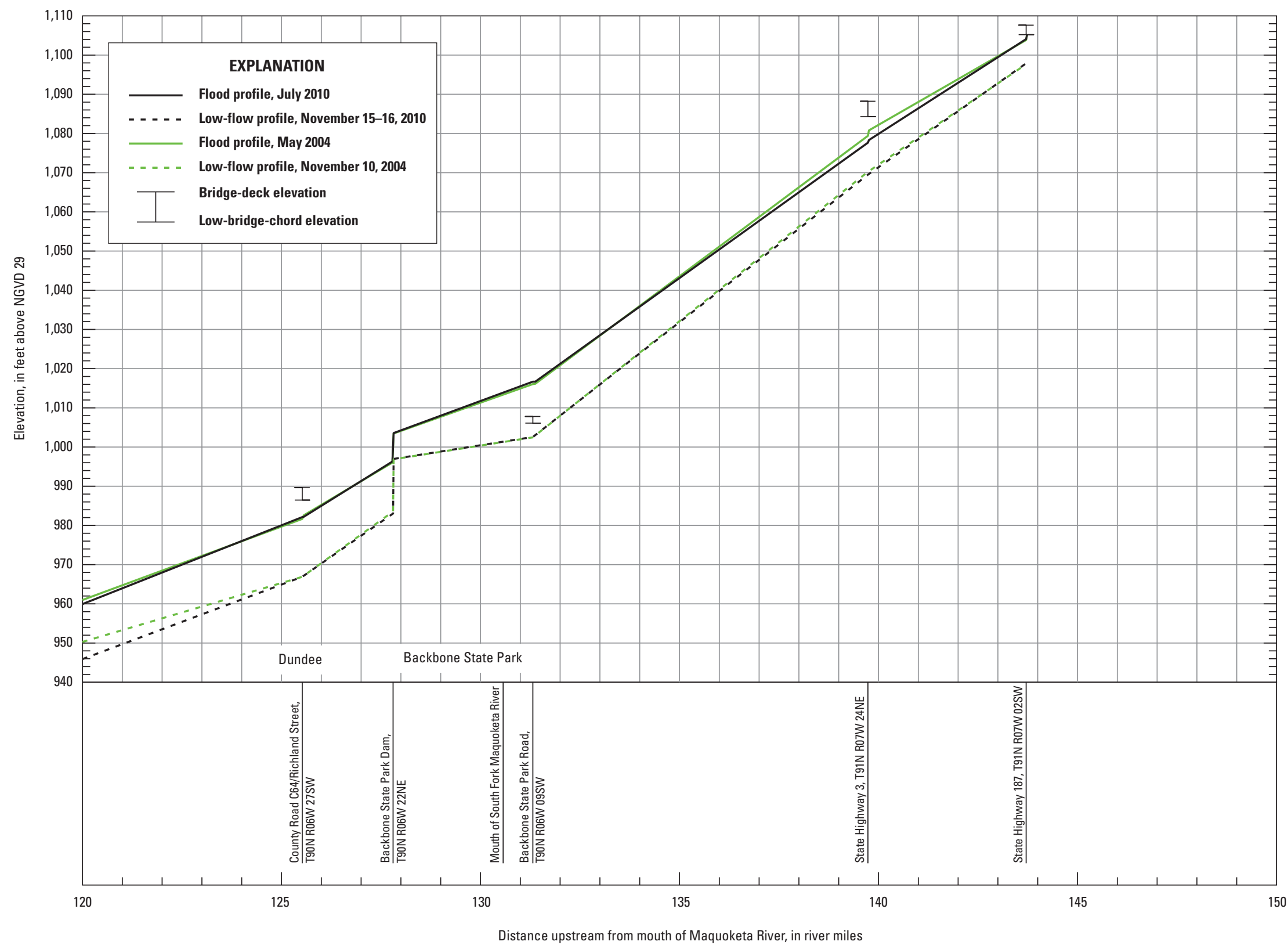

Figure 13. Profile of the July 23-26, 2010, flood for the Maquoketa River, river miles 120 to 144. 


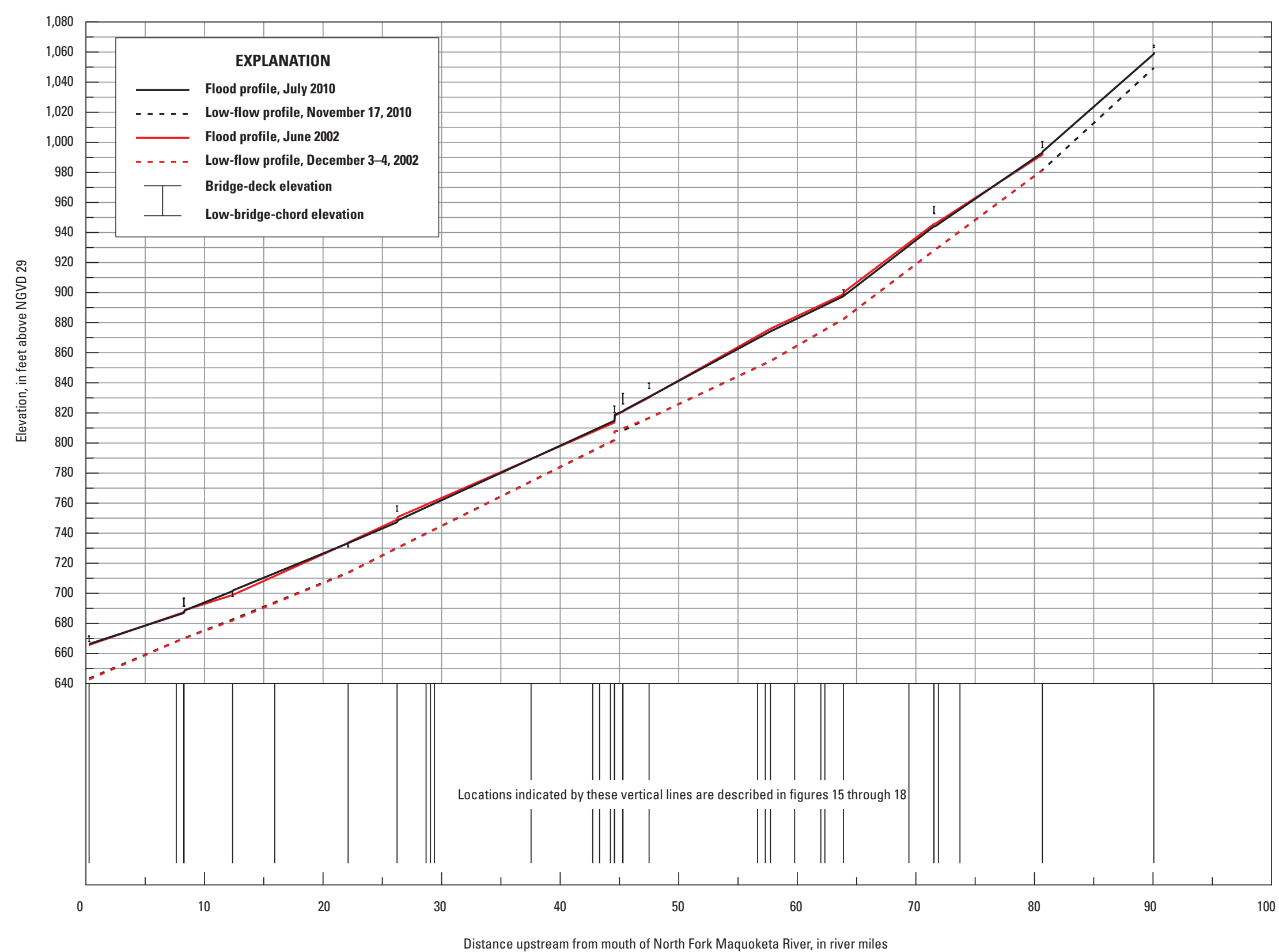

Figure 14. Profile of the July 23-24, 2010, flood for the North Fork Maquoketa River, river miles 0 to 90 . 


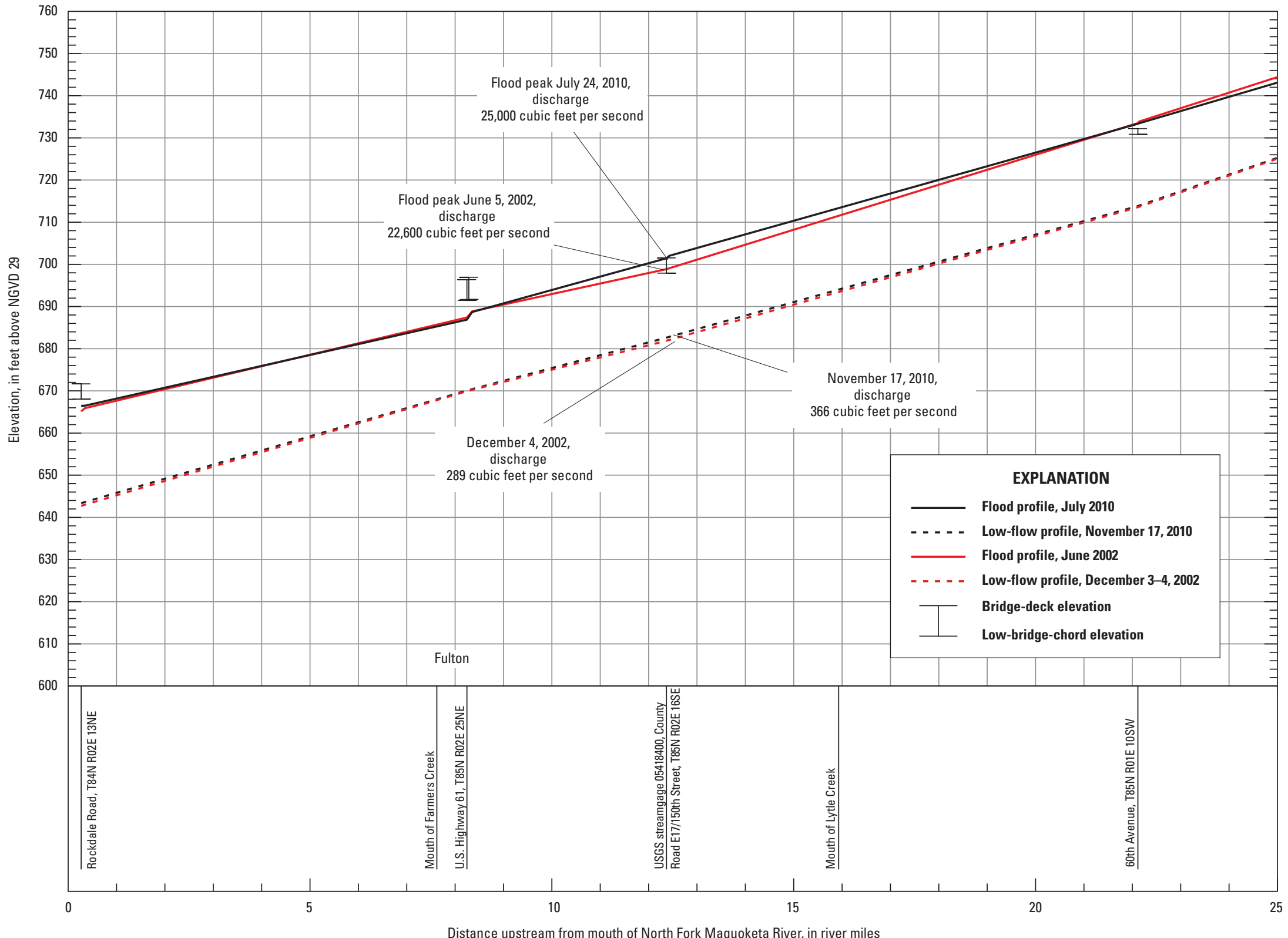

Figure 15. Profile of the July 23-24, 2010, flood for the North Fork Maquoketa River, river miles 0 to 25 . 


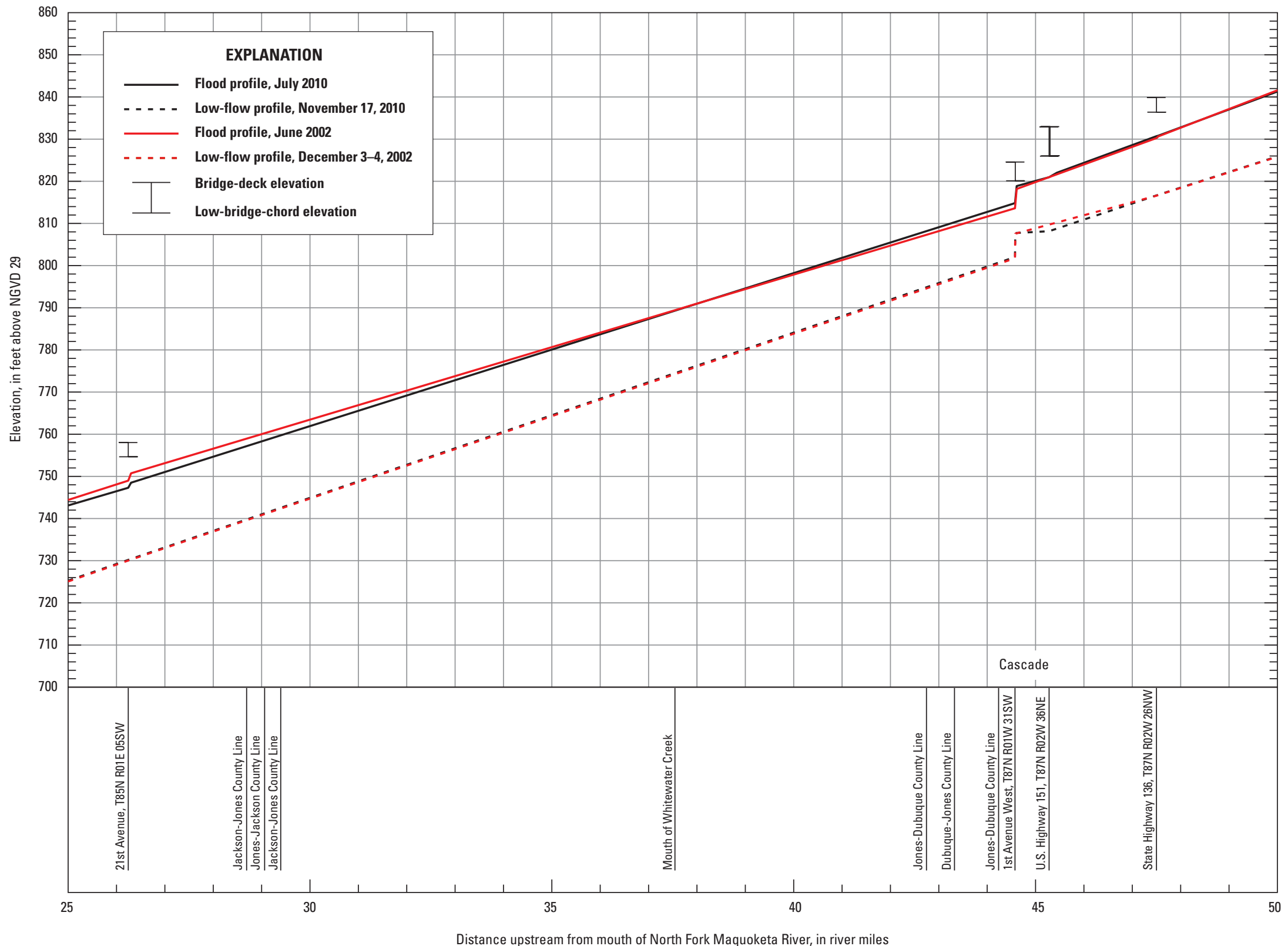

Figure 16. Profile of the July 23-24, 2010, flood for the North Fork Maquoketa River, river miles 25 to 50. 


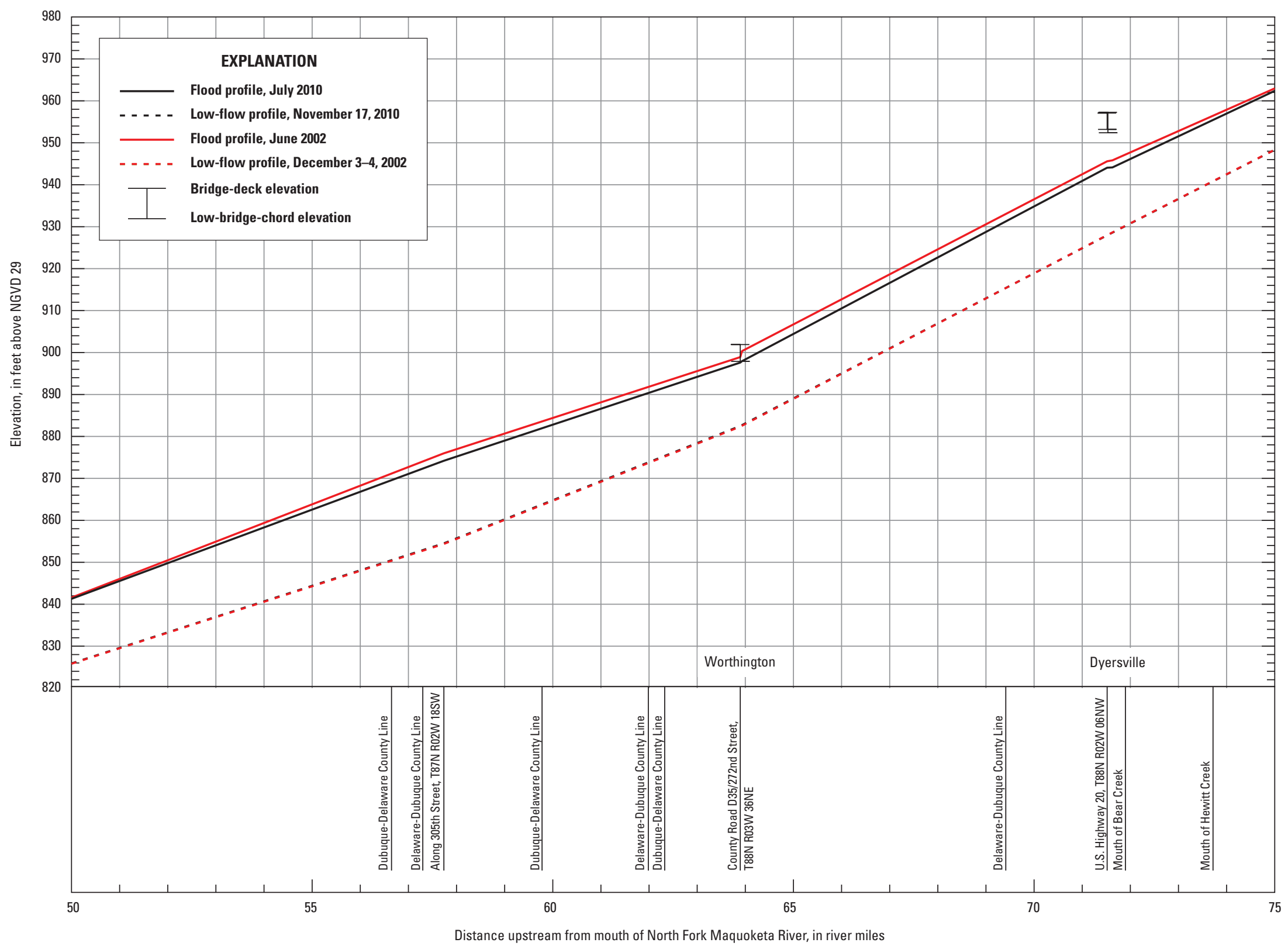

Figure 17. Profile of the July 23-24, 2010, flood for the North Fork Maquoketa River, river miles 50 to 75. 


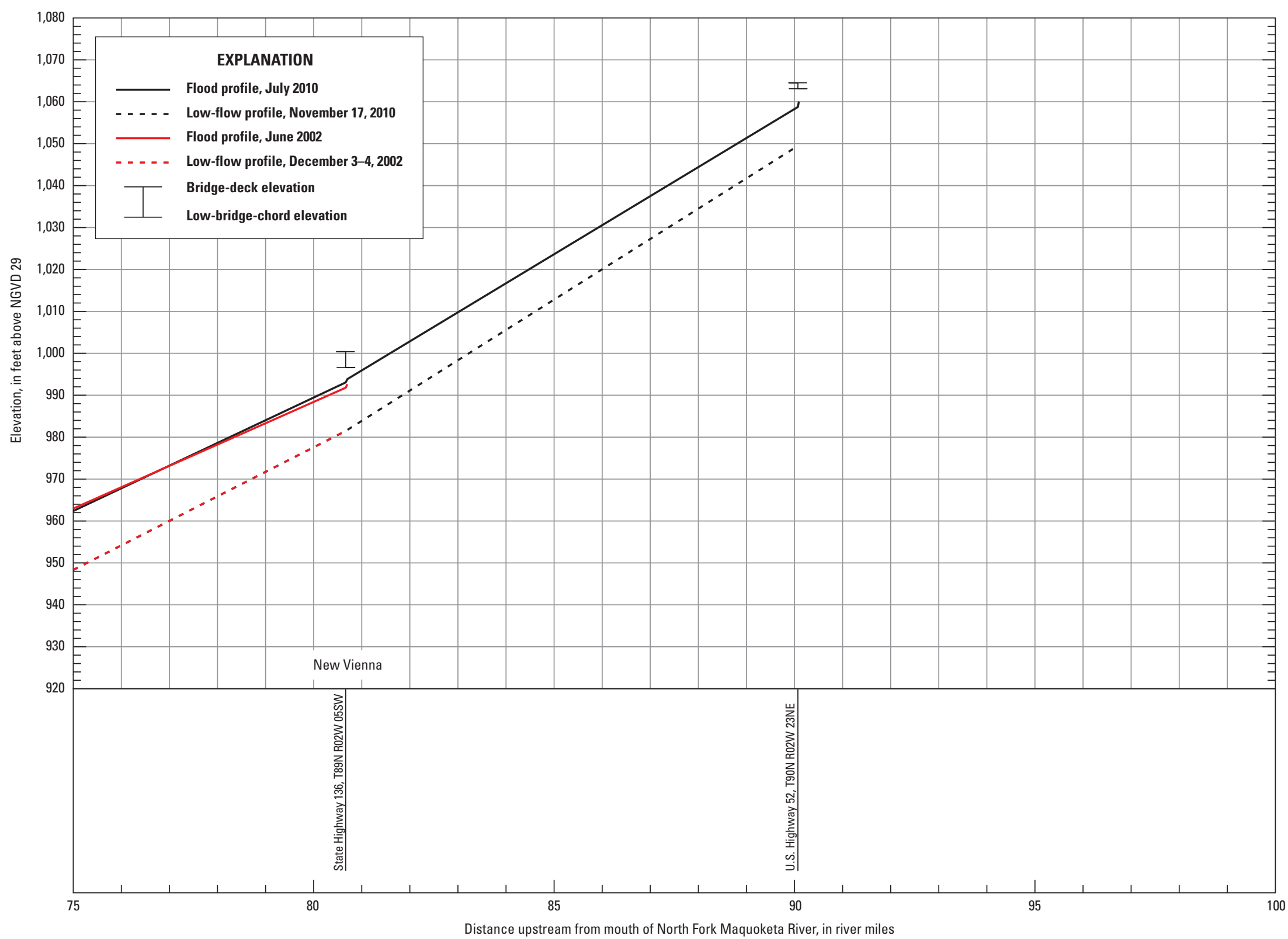

Figure 18. Profile of the July 23-24, 2010, flood for the North Fork Maquoketa River, river miles 75 to 100. 

Appendix 


\section{List of Bench Marks and Reference Points}

To facilitate measuring and referencing the high-water marks (HWMs) used in the flood profiles to a common datum, bench marks (BMs), temporary bench marks (TBMs), and reference points (RPs) were found or established by the U.S. Geological Survey (USGS) at selected bridges along the profiled river reaches. All BM, TBM, and RP elevations listed in appendix table 1 are referenced to the National Geodetic Vertical Datum of 1929. The list of 46 sites where the USGS measured HWMs for the July 2010 floods is shown in tables 7-9. Of these 46 sites, BMs or TBMs are listed for 44 of the sites and RPs are listed for 39 of the sites in appendix table 1. For 8 of the 46 sites listed in this appendix, elevations for BMs and TBMs were established by other agencies and these agencies are listed in appendix table 1. At USGS streamgages, BMs or TBMs are identified as reference marks (RMs) that are listed in appendix table 1 with an RM number. $\mathrm{BM}, \mathrm{TBM}$, and RP elevations established by the USGS were determined from a combination of global positioning system (GPS) technology and differential leveling. For 31 of the 46 sites listed in this appendix, elevations were established by the USGS using GPS and are noted in the BM, TBM, and RP descriptions. GPS data were collected by the USGS using two different methods. Static surveys of GPS data were submitted for processing to the Online Positioning User Service (OPUS), an Internet service provided by the National Geodetic Survey (http://www.ngs.noaa.gov/OPUS/). The quality of the OPUS GPS data is based on the guidelines of "What to look for in a quality solution" (http://www.ngs.noaa.gov/OPUS/about.html, accessed May 27, 2011). Real Time Kinematic (RTK) surveys of GPS data were processed using the IaRTN SmartNet, a Global Navigation Satellite System (GNSS) reference station network service provided by Iowa DOT and Leica Geosystems (http://spiderweb.iartn.com/spiderweb/frmIndex.aspx). The quality of the RTK GPS data is based on an average of multiple sets of GPS data collected using satellite configurations spaced at least 30 minutes apart, and on comparisons of elevations between RTK GPS surveys of GPS BMs and published elevations.
In general, BMs are points that were specifically designed to mark an elevation, such as USGS elevation disks and Iowa DOT BMs (round-top rods embedded in concrete at one or more corners of a bridge). Marks - such as squares and crosses that were chiseled or filed on concrete or metal, or existing bolts on bridges - were used as TBMs or RPs. RPs were established to permit water-surface elevations to be determined by use of a tape and weight. The terms "right" and "left" in the descriptions are determined as viewed while facing in the downstream direction.

The BMs, TBMs, and RPs are designated by an index number or legal description derived from their respective locations using Public Land Survey System coordinates (township, range, section). Within the section, the quarter section in which the BM, TBM, or RP is located is designated by NE, SE, NW, and SW. For example, T90N R02E $34 \mathrm{SW}$ refers to a location in Township 90 North, Range 2 East, southwest quarter of section 34. A number in parentheses following the quarter-section designation indicates the sequence number of the BM, TBM, or RP in that particular quarter section. The index number serves to describe the legal description of the mark without further reference in the body of the description. The physical location of the BM or TBM on a bridge dictates the appropriate legal description. The RPs, and any additional BMs or TBMs, are listed with the related BMs or TBMs and are identified by the same legal description though, at times, they are in a different section, range, or township as determined by upstream or downstream location.

The BMs, TBMs, and RPs are listed in appendix table 1 in upstream order for the Little Maquoketa, North Fork Little Maquoketa, Maquoketa, and North Fork Maquoketa Rivers. The user of this information is cautioned that BMs, TBMs, and RPs listed herein might have been disturbed, destroyed, or moved since elevations were established. It is the responsibility of the user to determine the condition and the suitability of the BM, TBM, or RP. 
Table 1. Bench marks and reference points used in the July 23-26, 2010, Little Maquoketa River, North Fork Little Maquoketa River, Maquoketa River, and North Fork Maquoketa River flood profiles.

[Bench marks and reference points are listed in upstream order. BM, bench mark; TBM, temporary bench mark; RP, reference point; GPS, Global Positioning System; USGS, U.S. Geological Survey; T, township; R, range; N, north; W, west; S, south; E, east; RM, reference mark; a number in parentheses following the quarter-section designation indicates the sequence number of the BM, TBM, or RP in that particular quarter section]

\begin{tabular}{|c|c|c|c|c|c|}
\hline $\begin{array}{l}\text { Public Land Survey } \\
\text { System } \\
\text { (township, range, section, } \\
\text { quarter section) }\end{array}$ & $\begin{array}{c}\text { Mark } \\
\text { classification }\end{array}$ & Location & Mark & $\begin{array}{l}\text { Elevation, } \\
\text { in feet } \\
\text { (NGVD } \\
\text { 1929) }\end{array}$ & $\begin{array}{l}\text { Elevation } \\
\text { determination } \\
\text { method }\end{array}$ \\
\hline \multicolumn{6}{|c|}{ Little Maquoketa River } \\
\hline T90N R02E 34 SW (1) & $\mathrm{BM}$ & $\begin{array}{l}\text { About } 0.25 \text { mile south of Sageville, on U.S. Highway } 52 \text { bridge over Little } \\
\text { Maquoketa River, on left downstream wingwall. }\end{array}$ & $\begin{array}{l}\text { Iowa Department of Transportation } \\
\text { bench mark }\end{array}$ & 634.25 & GPS \\
\hline T90N R02E 34 SW (2) & $\mathrm{RP}$ & $\begin{array}{l}\text { About } 0.25 \text { mile south of Sageville, on U.S. Highway } 52 \text { bridge over Little } \\
\text { Maquoketa River, at } 2 \text { nd drain from right downstream end of bridge. }\end{array}$ & Chiseled arrow & 633.52 & GPS \\
\hline T89N R02E 05 NE (1) & $\mathrm{BM}$ & $\begin{array}{l}\text { About } 1.5 \text { miles east of Durango, site of discontinued streamgage } 05414500 \\
\text { Little Maquoketa River near Durango, on Clay Hill Road bridge over } \\
\text { Little Maquoketa River, on left upstream wingwall. }\end{array}$ & USGS bench mark & 643.40 & GPS \\
\hline T89N R02E 05 NE (2) & $\mathrm{RP}$ & $\begin{array}{l}\text { About } 1.5 \text { miles east of Durango, site of discontinued streamgage } 05414500 \\
\text { Little Maquoketa River near Durango, on Clay Hill Road bridge over } \\
\text { Little Maquoketa River, between 18th and 19th vertical concrete pillars } \\
\text { from end of bridge. }\end{array}$ & Chiseled arrow & 643.08 & GPS \\
\hline \multicolumn{6}{|c|}{ North Fork Little Maquoketa River } \\
\hline T90N R01E 35 NE (1) & $\mathrm{BM}$ & $\begin{array}{l}\text { About } 1.5 \text { miles northwest of Durango, on U.S. Highway } 52 \text { bridge over } \\
\text { North Fork Little Maquoketa River, on concrete rail at left downstream } \\
\text { end of bridge. }\end{array}$ & $\begin{array}{l}\text { National Geodetic Survey U.S. Coast } \\
\text { \& Geodetic Survey bench mark } \\
\text { stamped "R177 reset 1995" }\end{array}$ & 669.85 & GPS \\
\hline T90N R01E 35 NE (2) & $\mathrm{RP}$ & $\begin{array}{l}\text { About } 1.5 \text { miles northwest of Durango, on U.S. Highway } 52 \text { bridge over } \\
\text { North Fork Little Maquoketa River, on downstream concrete lip between } \\
\text { 1st and 2nd drains. }\end{array}$ & Chiseled arrow & 668.06 & GPS \\
\hline T90N R01E 28 NW (1) & TBM & $\begin{array}{l}\text { About } 1.3 \text { miles east of Rickardsville, site of streamgage } 05414450 \text { North } \\
\text { Fork Little Maquoketa River near Rickardsville, on South Mound Road } \\
\text { bridge over North Fork Little Maquoketa River, on bolt head } 1 \text { foot below } \\
\text { curb at left upstream end of bridge. }\end{array}$ & Chiseled cross. & 760.71 & GPS \\
\hline T90N R01E 28 NW (2) & $\mathrm{RP}$ & $\begin{array}{l}\text { About } 1.3 \text { miles east of Rickardsville, site of streamgage } 05414450 \text { North } \\
\text { Fork Little Maquoketa River near Rickardsville, on South Mound Road } \\
\text { bridge over North Fork Little Maquoketa River, on largest metal rail about } \\
30 \text { feet from left downstream end of bridge. }\end{array}$ & Three filed marks & 766.14 & GPS \\
\hline T90N R01E 19 NW (1) & TBM & $\begin{array}{l}\text { About } 0.75 \text { mile northwest of Rickardsville, on James Road bridge over } \\
\text { North Fork Little Maquoketa River, on right downstream wingwall. }\end{array}$ & Chiseled square. & 857.85 & GPS \\
\hline T90N R01E 19 NW (2) & $\mathrm{RP}$ & $\begin{array}{l}\text { About } 0.75 \text { mile northwest of Rickardsville, on James Road bridge over } \\
\text { North Fork Little Maquoketa River, on downstream concrete rail at middle } \\
\text { of bridge. }\end{array}$ & Chiseled arrow & 856.79 & GPS \\
\hline
\end{tabular}


Table 1. Bench marks and reference points used in the July 23-26, 2010, Little Maquoketa River, North Fork Little Maquoketa River, Maquoketa River, and North Fork Maquoketa River flood profiles.-Continued

[Bench marks and reference points are listed in upstream order. BM, bench mark; TBM, temporary bench mark; RP, reference point; GPS, Global Positioning System; USGS, U.S. Geological Survey; T, township; R, range; N, north; W, west; S, south; E, east; RM, reference mark; a number in parentheses following the quarter-section designation indicates the sequence number of the BM, TBM, or RP in that particular quarter section]

\begin{tabular}{|c|c|c|c|c|c|}
\hline $\begin{array}{l}\text { Public Land Survey } \\
\text { System } \\
\text { (township, range, section, } \\
\text { quarter section) }\end{array}$ & $\begin{array}{l}\text { Mark } \\
\text { classification }\end{array}$ & Location & Mark & $\begin{array}{l}\text { Elevation, } \\
\text { in feet } \\
\text { (NGVD } \\
\text { 1929) }\end{array}$ & $\begin{array}{l}\text { Elevation } \\
\text { determination } \\
\text { method }\end{array}$ \\
\hline \multicolumn{6}{|c|}{ Maquoketa River } \\
\hline T85N R05E 23 NE (1) & BM & $\begin{array}{l}\text { About } 1 \text { mile northwest of Green Island, on U.S. Highway } 52 \text { bridge over } \\
\text { Maquoketa River, on right downstream wingwall. }\end{array}$ & $\begin{array}{l}\text { Iowa Department of Transportation } \\
\text { bench mark }\end{array}$ & 615.70 & GPS \\
\hline T85N R05E 23 NE (2) & BM & $\begin{array}{l}\text { About } 1 \text { mile northwest of Green Island, on U.S. Highway } 52 \text { bridge over } \\
\text { Maquoketa River, on left upstream wingwall. }\end{array}$ & $\begin{array}{l}\text { Iowa Department of Transportation } \\
\text { bench mark. }\end{array}$ & 615.69 & GPS \\
\hline T85N R05E 23 NE (3) & BM & $\begin{array}{l}\text { About } 1 \text { mile northwest of Green Island, on U.S. Highway } 52 \text { bridge over } \\
\text { Maquoketa River, on concrete platform at curb level at left upstream end } \\
\text { of bridge. }\end{array}$ & $\begin{array}{l}\text { Iowa Department of Transportation } \\
\text { bench mark. }\end{array}$ & 613.57 & GPS \\
\hline T85N R05E 23 NE (4) & $\mathrm{RP}$ & $\begin{array}{l}\text { About } 1 \text { mile northwest of Green Island, on U.S. Highway } 52 \text { bridge over } \\
\text { Maquoketa River, on concrete platform behind 7th drain from left down- } \\
\text { stream end of bridge. }\end{array}$ & Chiseled square. & 614.29 & GPS \\
\hline T84N R04E 13 SE (1) & TBM & $\begin{array}{l}\text { About } 0.75 \text { mile north of Spragueville, on County Road Z20/387th Avenue } \\
\text { bridge over Maquoketa River, on outer wingwall about } 1.5 \mathrm{ft} \text { from guard- } \\
\text { rail at left downstream end of bridge. }\end{array}$ & Chiseled square. & 635.01 & GPS \\
\hline T84N R04E 13 SE (2) & $\mathrm{RP}$ & $\begin{array}{l}\text { About } 0.75 \text { mile north of Spragueville, on County Road Z20/387th Avenue } \\
\text { bridge over Maquoketa River, behind 18th guardrail post from right down- } \\
\text { stream end of bridge. }\end{array}$ & Three filed marks & 638.93 & GPS \\
\hline T84N R04E 08 NE (1) & TBM & $\begin{array}{l}\text { About } 5 \text { miles southeast of Andrew, on County Road E23Y/Iron Bridge Road } \\
\text { over Maquoketa River, on corner of lower wingwall at left upstream end } \\
\text { of bridge. }\end{array}$ & Chiseled square & 647.40 & GPS \\
\hline T84N R04E 08 NE (2) & $\mathrm{RP}$ & $\begin{array}{l}\text { About } 5 \text { miles southeast of Andrew, on County Road E23Y/Iron Bridge Road } \\
\text { over Maquoketa River, on guardrail about } 8 \text { feet left of } 2 \text { nd vertical truss } \\
\text { member from right downstream end of bridge. }\end{array}$ & Three filed marks & 661.14 & GPS \\
\hline T84N R03E 17 NE (1) & TBM & $\begin{array}{l}\text { About } 1.5 \text { miles northeast of Maquoketa, site of streamgage } 05418500 \\
\text { Maquoketa River near Maquoketa, on State Highway } 62 \text { bridge over } \\
\text { Maquoketa River, on right downstream abutment. }\end{array}$ & Chiseled square (RM 19) & 670.77 & Streamgage elevation data \\
\hline T84N R03E 17 NE (2) & TBM & $\begin{array}{l}\text { About } 1.5 \text { miles northeast of Maquoketa, site of streamgage } 05418500 \\
\text { Maquoketa River near Maquoketa, on State Highway } 62 \text { bridge over } \\
\text { Maquoketa River, on right upstream abutment. }\end{array}$ & Chiseled square (RM 20) & 670.78 & Streamgage elevation data \\
\hline T84N R02E 24 NW (1) & BM & $\begin{array}{l}\text { At Maquoketa, on northbound lane of U.S. Highway } 61 \text { bridge over Maquo- } \\
\text { keta River (downstream bridge), on right upstream wingwall. }\end{array}$ & $\begin{array}{l}\text { Iowa Department of Transportation } \\
\text { bench mark }\end{array}$ & 683.94 & $\begin{array}{l}\text { Elevation supplied by Iowa } \\
\text { Department of Transpor- } \\
\text { tation }\end{array}$ \\
\hline
\end{tabular}


Table 1. Bench marks and reference points used in the July 23-26, 2010, Little Maquoketa River, North Fork Little Maquoketa River, Maquoketa River, and North Fork Maquoketa River flood profiles.-Continued

[Bench marks and reference points are listed in upstream order. BM, bench mark; TBM, temporary bench mark; RP, reference point; GPS, Global Positioning System; USGS, U.S. Geological Survey; T, township; R, range; N, north; W, west; S, south; E, east; RM, reference mark; a number in parentheses following the quarter-section designation indicates the sequence number of the BM, TBM, or RP in that particular quarter section]

\begin{tabular}{|c|c|c|c|c|c|}
\hline $\begin{array}{l}\text { Public Land Survey } \\
\text { System } \\
\text { (township, range, section, } \\
\text { quarter section) }\end{array}$ & $\begin{array}{l}\text { Mark } \\
\text { classification }\end{array}$ & Location & Mark & $\begin{array}{l}\text { Elevation, } \\
\text { in feet } \\
\text { (NGVD } \\
\text { 1929) }\end{array}$ & $\begin{array}{l}\text { Elevation } \\
\text { determination } \\
\text { method }\end{array}$ \\
\hline \multicolumn{6}{|c|}{ Maquoketa River-Continued } \\
\hline T84N R02E 24 NW (2) & $\mathrm{BM}$ & $\begin{array}{l}\text { At Maquoketa, on southbound lane of U.S. Highway } 61 \text { bridge over } \\
\text { Maquoketa River (upstream bridge), on right downstream wingwall. }\end{array}$ & $\begin{array}{l}\text { Iowa Department of Transportation } \\
\text { bench mark }\end{array}$ & 699.76 & $\begin{array}{l}\text { Elevation surveyed from } \\
\text { Iowa Department of } \\
\text { Transportation bench } \\
\text { mark }\end{array}$ \\
\hline T84N R02E 24 NW (3) & $\mathrm{RP}$ & $\begin{array}{l}\text { At Maquoketa, on northbound lane of U.S. Highway } 61 \text { bridge over } \\
\text { Maquoketa River (downstream bridge), on concrete platform behind } \\
\text { 7th drain from either end of bridge. }\end{array}$ & Chiseled square & 683.08 & $\begin{array}{l}\text { Elevation surveyed from } \\
\text { Iowa Department of } \\
\text { Transportation bench } \\
\text { mark }\end{array}$ \\
\hline T84N R01E 03 NE (1) & TBM & $\begin{array}{l}\text { About } 3.2 \text { miles northeast of Baldwin, on County Road Y34/50th Avenue } \\
\text { bridge over Maquoketa River, on left downstream concrete rail. }\end{array}$ & Chiseled square & 728.72 & GPS \\
\hline T84N R01E 03 NE (2) & $\mathrm{RP}$ & $\begin{array}{l}\text { About } 3.2 \text { miles northeast of Baldwin, on County Road Y34/50th Avenue } \\
\text { bridge over Maquoketa River, on meatal rail at 4th drain from left down- } \\
\text { stream end of bridge. }\end{array}$ & Three filed marks & 725.82 & GPS \\
\hline T85N R01E 33 SW (1) & TBM & $\begin{array}{l}\text { About } 3.5 \text { miles north of Monmouth, on 30th Avenue bridge over Maquoketa } \\
\text { River, on threaded bolt on outer downstream end of left downstream pier. }\end{array}$ & Filed cross & 713.56 & GPS \\
\hline T85N R01E 33 SW (2) & $\mathrm{RP}$ & $\begin{array}{l}\text { About } 3.5 \text { miles north of Monmouth, on } 30 \text { th Avenue bridge over Maquoketa } \\
\text { River, on guardrail about } 0.5 \text { foot left of guardrail post between } 2 \text { nd and } \\
\text { 3rd vertical truss members from left downstream end of bridge. }\end{array}$ & Three file marks & 719.18 & GPS \\
\hline T85N R01W 08 SE (1) & TBM & $\begin{array}{l}\text { About } 4.25 \text { miles northwest of Canton, on Temple Hill Road bridge over } \\
\text { Maquoketa River, on right downstream wingwall. }\end{array}$ & Chiseled cross & 749.79 & GPS \\
\hline T85N R01W 08 SE (2) & $\mathrm{RP}$ & $\begin{array}{l}\text { About } 4.25 \text { miles northwest of Canton, on Temple Hill Road bridge over } \\
\text { Maquoketa River, on concrete barrier wall at 20th concrete post from left } \\
\text { downstream end of bridge. }\end{array}$ & Chiseled square & 746.61 & GPS \\
\hline T85N R01W 06 NW (1) & $\mathrm{BM}$ & $\begin{array}{l}\text { About } 5.75 \text { miles northeast of Scotch Grove, on State Highway } 136 \text { bridge } \\
\text { over Maquoketa River, on left upstream wingwall. }\end{array}$ & $\begin{array}{l}\text { Iowa Department of Transportation } \\
\text { bench mark }\end{array}$ & 756.74 & GPS \\
\hline T85N R01W 06 NW (2) & $\mathrm{RP}$ & $\begin{array}{l}\text { About } 5.75 \text { miles northeast of Scotch Grove, on State Highway } 136 \text { bridge } \\
\text { over Maquoketa River, on concrete platform behind 4th drain from left } \\
\text { downstream end of bridge. }\end{array}$ & Chiseled square & 757.03 & GPS \\
\hline T85N R02W 03 SE (1) & $\mathrm{BM}$ & $\begin{array}{l}\text { About } 3 \text { miles northeast of Scotch Grove, on Ebys Mill Road bridge over } \\
\text { Maquoketa River, on right downstream concrete rail. }\end{array}$ & Brass tablet & 774.43 & GPS \\
\hline T85N R02W 03 SE (2) & $\mathrm{RP}$ & $\begin{array}{l}\text { About } 3 \text { miles northeast of Scotch Grove, on Ebys Mill Road bridge over } \\
\text { Maquoketa River, on downstream concrete rail at } 27 \text { th vertical rail from } \\
\text { right end of bridge. }\end{array}$ & Chiseled arrow & 772.74 & GPS \\
\hline
\end{tabular}


Table 1. Bench marks and reference points used in the July 23-26, 2010, Little Maquoketa River, North Fork Little Maquoketa River, Maquoketa River, and North Fork Maquoketa River flood profiles.-Continued

[Bench marks and reference points are listed in upstream order. BM, bench mark; TBM, temporary bench mark; RP, reference point; GPS, Global Positioning System; USGS, U.S. Geological Survey; T, township; R, range; N, north; W, west; S, south; E, east; RM, reference mark; a number in parentheses following the quarter-section designation indicates the sequence number of the BM, TBM, or RP in that particular quarter section]

\begin{tabular}{|c|c|c|c|c|}
\hline 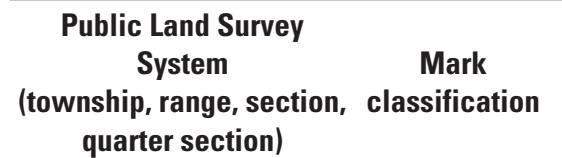 & Location & Mark & $\begin{array}{l}\text { Elevation, } \\
\text { in feet } \\
\text { (NGVD } \\
\text { 1929) }\end{array}$ & $\begin{array}{l}\text { Elevation } \\
\text { determination } \\
\text { method }\end{array}$ \\
\hline
\end{tabular}

\begin{tabular}{llll}
\multicolumn{1}{c}{ Maquoketa River-Continued } \\
\hline T86N R03W 23 NW (1) BM $\quad$ About 1 mile northeast of Monticello, on northbound lane of US. Highway Iowa Department of Transportation $854.86 \quad$ GPS
\end{tabular}
151 bridge over Maquoketa River (downstream bridge), on right down- bench mark. stream concrete rail.

T86N R03W 23 NW (2)

RP

T86N R03W 22 SE (1)

$\mathrm{BM}$

T86N R03W 22 SE (2)

RP

T86N R03W 16 NE (1)

T86N R03W 16 NE (2)

T87N R04W 24 NW (1)

T87N R04W 24 NW (2)

T88N R04W 30 NE (1)
At Monticello, on Main Street bridge over Maquoketa River, on concrete platform behind 7 th drain from left downstream end of bridge.

About 1 mile northeast of Monticello, on northbound lane of U.S. Highway Chiseled arrow 151 bridge over Maquoketa River (downstream bridge), on downstream concrete rail at 4th drain from right end of bridge.

At Monticello, on Main Street bridge over Maquoketa River, on outside curb Iowa Department of Transportation behind guardwall at left upstream end of bridge. bench mark

Chiseled square

At Monticello, on State Highway 38 bridge over Maquoketa River, on left upstream wingwall.

lowa Department of Transportation bench mark

Chiseled square

At Monticello, on State Highway 38 bridge over Maquoketa River, on concrete platform right of 21 st metal bracket from right downstream end of bridge and across from center of 3rd and 4th drains from right upstream end of bridge.

About 0.5 mile southwest of Hopkinton, on County Road D47/Marion Street Delaware County bench mark bridge over southern channel of Maquoketa River, on left downstream end of sidewalk concrete barrier wall.

About 0.5 mile southwest of Hopkinton, on County Road D47/Marion Street Edge of concrete sidewalk bridge over southern channel of Maquoketa River, on downstream side of cyclone fence at 12th fence post from right downstream end of bridge.

About 1.5 miles southwest of Delhi, on County Road X31/230th Avenue crossing Lake Delhi dam on Maquoketa River, on end of right down-

Chiseled cross stream wingwall.

About 2 miles southwest of Delhi, on County Road X29/220th Avenue bridge Delaware County bench mark over Lake Delhi, on concrete rail at left upstream end of bridge.
909.60 GPS 
Table 1. Bench marks and reference points used in the July 23-26, 2010, Little Maquoketa River, North Fork Little Maquoketa River, Maquoketa River, and North Fork Maquoketa River flood profiles.-Continued

[Bench marks and reference points are listed in upstream order. BM, bench mark; TBM, temporary bench mark; RP, reference point; GPS, Global Positioning System; USGS, U.S. Geological Survey; T, township; R, range; N, north; W, west; S, south; E, east; RM, reference mark; a number in parentheses following the quarter-section designation indicates the sequence number of the BM, TBM, or RP in that particular quarter section]

\begin{tabular}{|c|c|c|c|c|c|}
\hline $\begin{array}{l}\text { Public Land Survey } \\
\text { System } \\
\text { (township, range, section, } \\
\text { quarter section) }\end{array}$ & $\begin{array}{l}\text { Mark } \\
\text { classification }\end{array}$ & Location & Mark & $\begin{array}{l}\text { Elevation, } \\
\text { in feet } \\
\text { (NGVD } \\
\text { 1929) }\end{array}$ & $\begin{array}{l}\text { Elevation } \\
\text { determination } \\
\text { method }\end{array}$ \\
\hline \multicolumn{6}{|c|}{ Maquoketa River-Continued } \\
\hline T88N R04W 30 NW (2) & $\mathrm{RP}$ & $\begin{array}{l}\text { About } 2 \text { miles southwest of Delhi, on County Road X29/220th Avenue bridge } \\
\text { over Lake Delhi, on } 22 \text { nd vertical concrete post from left downstream end } \\
\text { of bridge. }\end{array}$ & Chiseled arrow & 913.54 & GPS \\
\hline T88N R05W 15 NE (1) & TBM & $\begin{array}{l}\text { About } 4 \text { miles southeast of Manchester, on County Road X21/240th Street } \\
\text { bridge over Maquoketa River, on corner of wingwall near guardrail at } \\
\text { right upstream end of bridge. }\end{array}$ & Chiseled square & 915.58 & GPS \\
\hline T88N R05W 15 NE (2) & RP & $\begin{array}{l}\text { About } 4 \text { miles southeast of Manchester, on County Road X21/240th Street } \\
\text { bridge over Maquoketa River, on metal guardrail behind 3rd drain from } \\
\text { right downstream end of bridge. }\end{array}$ & Three filed marks & 917.32 & GPS \\
\hline T89N R05W 33 SW(1) & BM & $\begin{array}{l}\text { About } 0.5 \text { mile south of Manchester, on eastbound lane of U.S. Highway } \\
20 \text { bridge over Maquoketa River (downstream bridge), on left upstream } \\
\text { abutment. }\end{array}$ & $\begin{array}{l}\text { Iowa Department of Transportation } \\
\text { bench mark (RM 1) }\end{array}$ & 938.14 & GPS \\
\hline T89N R05W 33 SW(2) & TBM & $\begin{array}{l}\text { About } 0.5 \text { mile south of Manchester, on eastbound lane of U.S. Highway } 20 \\
\text { bridge over Maquoketa River (downstream bridge), on left downstream } \\
\text { abutment. }\end{array}$ & Chiseled square (RM 2) & 938.34 & GPS \\
\hline T89N R05W 32 NE (1) & TBM & $\begin{array}{l}\text { At Manchester, on Marion Street bridge over Maquoketa River, at left down- } \\
\text { stream end of bridge underneath Marion Street bridge sign. }\end{array}$ & Chiseled cross & 939.00 & $\begin{array}{l}\text { Elevation surveyed from } \\
\text { USGS bench mark at Post } \\
\text { Office }\end{array}$ \\
\hline T89N R05W 32 NE (2) & TBM & $\begin{array}{l}\text { At Manchester, on Marion Street bridge over Maquoketa River, on retaining } \\
\text { wall at left upstream abutment. }\end{array}$ & Chiseled cross & 938.93 & $\begin{array}{l}\text { Elevation surveyed from } \\
\text { USGS bench mark at Post } \\
\text { Office }\end{array}$ \\
\hline T89N R05W 32 NE (3) & RP & $\begin{array}{l}\text { At Manchester, on Marion Street bridge over Maquoketa River, beneath } \\
\text { metal box attached to downstream guardrail. }\end{array}$ & Edge of concrete sidewalk & 940.72 & $\begin{array}{l}\text { Elevation surveyed from } \\
\text { USGS bench mark at Post } \\
\text { Office }\end{array}$ \\
\hline T89N R05W 32 NW (1) & $\mathrm{BM}$ & $\begin{array}{l}\text { At Manchester, on State Highway 13/West Main Street bridge over Maquo- } \\
\text { keta River, on left downstream end of sidewalk concrete barrier wall at } \\
\text { end of metal rail. }\end{array}$ & $\begin{array}{l}\text { Iowa Department of Transportation } \\
\text { bench mark }\end{array}$ & 944.30 & $\begin{array}{l}\text { Elevation supplied by Iowa } \\
\text { Department of Transpor- } \\
\text { tation }\end{array}$ \\
\hline T89N R05W 32 NW (2) & $\mathrm{RP}$ & $\begin{array}{l}\text { At Manchester, on State Highway 13/West Main Street bridge over Maquo- } \\
\text { keta River, on downstream side of cyclone fence at 10th fence post from } \\
\text { left downstream end of bridge. }\end{array}$ & Edge of concrete sidewalk & 945.08 & $\begin{array}{l}\text { Elevation surveyed from } \\
\text { Iowa Department of } \\
\text { Transportation bench } \\
\text { mark }\end{array}$ \\
\hline T89N R05W 19 NE (1) & TBM & $\begin{array}{l}\text { About } 0.5 \text { mile northwest of Manchester, on 195th Street bridge over Maquo- } \\
\text { keta River, on right upstream end of lower wingwall. }\end{array}$ & Chiseled square & 943.11 & GPS \\
\hline
\end{tabular}


Table 1. Bench marks and reference points used in the July 23-26, 2010, Little Maquoketa River, North Fork Little Maquoketa River, Maquoketa River, and North Fork Maquoketa River flood profiles.-Continued

[Bench marks and reference points are listed in upstream order. BM, bench mark; TBM, temporary bench mark; RP, reference point; GPS, Global Positioning System; USGS, U.S. Geological Survey; T, township; R, range; N, north; W, west; S, south; E, east; RM, reference mark; a number in parentheses following the quarter-section designation indicates the sequence number of the BM, TBM, or RP in that particular quarter section]

\begin{tabular}{|c|c|c|c|c|c|}
\hline $\begin{array}{l}\text { Public Land Survey } \\
\text { System } \\
\text { (township, range, section, } \\
\text { quarter section) }\end{array}$ & $\begin{array}{l}\text { Mark } \\
\text { classification }\end{array}$ & Location & Mark & $\begin{array}{l}\text { Elevation, } \\
\text { in feet } \\
\text { (NGVD } \\
\text { 1929) }\end{array}$ & $\begin{array}{l}\text { Elevation } \\
\text { determination } \\
\text { method }\end{array}$ \\
\hline \multicolumn{6}{|c|}{ Maquoketa River-Continued } \\
\hline T89N R05W 19 NE (2) & $\mathrm{RP}$ & $\begin{array}{l}\text { About } 0.5 \text { mile northwest of Manchester, on } 195 \text { th Street bridge over } \\
\text { Maquoketa River, on downstream metal rail between 3rd and 4th drains } \\
\text { from left end of bridge. }\end{array}$ & Three filed marks & 945.78 & GPS \\
\hline T90N R06W 27 SW (1) & TBM & $\begin{array}{l}\text { At west edge of Dundee, on County Road C64/Richland Street bridge over } \\
\text { Maquoketa River, on right upstream end of concrete rail. }\end{array}$ & Chiseled square & 991.96 & GPS \\
\hline T90N R06W 27 SW (2) & $\mathrm{BM}$ & $\begin{array}{l}\text { At west edge of Dundee, on County Road C64/Richland Street bridge over } \\
\text { Maquoketa River, on left downstream concrete rail. }\end{array}$ & Delaware County bench mark & 996.20 & GPS \\
\hline T90N R06W 27 SW (3) & $\mathrm{RP}$ & $\begin{array}{l}\text { At west edge of Dundee, on County Road C64/Richland Street bridge over } \\
\text { Maquoketa River, on downstream concrete rail near middle of channel. }\end{array}$ & Chiseled arrow & 994.59 & GPS \\
\hline T90N R06W 22 NE (1) & TBM & $\begin{array}{l}\text { At Backbone State Park, on southeast dam of two dams across Maquoketa } \\
\text { River, below cyclone fence on downstream end of upper horizontal con- } \\
\text { crete structure on left end of dam. }\end{array}$ & Chiseled square & 1007.34 & GPS \\
\hline T90N R06W 22 NE (2) & $\mathrm{RP}$ & $\begin{array}{l}\text { At Backbone State Park, on southeast dam of two dams across Maquoketa } \\
\text { River, below cyclone fence on upstream end of upper horizontal concrete } \\
\text { structure on left end of dam. }\end{array}$ & $\begin{array}{l}\text { Most upstream edge of upper hori- } \\
\text { zontal concrete surface }\end{array}$ & 1007.48 & GPS \\
\hline T90N R06W 22 NE (3) & $\mathrm{RP}$ & $\begin{array}{l}\text { At Backbone State Park, on southeast dam of two dams across Maquoketa } \\
\text { River, behind cyclone fence post on upstream end of lower horizontal } \\
\text { concrete structure on left end of dam. }\end{array}$ & $\begin{array}{l}\text { Most upstream edge of lower hori- } \\
\text { zontal concrete surface }\end{array}$ & 996.08 & GPS \\
\hline T90N R06W 09 SW (1) & $\mathrm{BM}$ & $\begin{array}{l}\text { At Backbone State Park, on County Road C57/ 120th Street bridge over } \\
\text { Maquoketa River, on right downstream wingwall. }\end{array}$ & $\begin{array}{l}\text { Iowa Department of Transportation } \\
\text { bench mark }\end{array}$ & $1,010.28$ & GPS \\
\hline T90N R06W 09 SW (2) & $\mathrm{RP}$ & $\begin{array}{l}\text { At Backbone State Park, on County Road C57/ 120th Street bridge over } \\
\text { Maquoketa River, on downstream concrete barrier wall about } 1 \text { foot right } \\
\text { of center of concrete sections. }\end{array}$ & Chiseled square & $1,010.27$ & GPS \\
\hline T91N R07W 24 NE (1) & $\mathrm{BM}$ & $\begin{array}{l}\text { About } 3.5 \text { miles west of Strawberry Point, on State Highway } 3 \text { bridge over } \\
\text { Maquoketa River, on left downstream lower wingwall. }\end{array}$ & $\begin{array}{l}\text { Iowa Department of Transportation } \\
\text { bench mark }\end{array}$ & $1,088.42$ & $\begin{array}{l}\text { Elevation supplied by Iowa } \\
\text { Department of Transpor- } \\
\text { tation }\end{array}$ \\
\hline T91N R07W 24 NE (2) & $\mathrm{RP}$ & $\begin{array}{l}\text { About } 3.5 \text { miles west of Strawberry Point, on State Highway } 3 \text { bridge over } \\
\text { Maquoketa River, on outer concrete platform behind 8th guardrail post } \\
\text { from left downstream end of bridge. }\end{array}$ & Chiseled square & $1,089.44$ & $\begin{array}{l}\text { Elevation surveyed from } \\
\text { Iowa Department of } \\
\text { Transportation bench } \\
\text { mark }\end{array}$ \\
\hline T91N R07W 02 SW (1) & $\mathrm{BM}$ & $\begin{array}{l}\text { About } 2.25 \text { miles southeast of Arlington, on State Highway } 187 \text { bridge over } \\
\text { Maquoketa River, on left downstream wingwall. }\end{array}$ & $\begin{array}{l}\text { Iowa Department of Transportation } \\
\text { bench mark }\end{array}$ & $1,109.99$ & GPS \\
\hline T91N R07W 02 SW (2) & $\mathrm{RP}$ & $\begin{array}{l}\text { About } 2.25 \text { miles southeast of Arlington, on State Highway } 187 \text { bridge over } \\
\text { Maquoketa River, on outer concrete platform behind 3rd drain from right } \\
\text { downstream end of bridge. }\end{array}$ & Chiseled square & $1,108.37$ & GPS \\
\hline
\end{tabular}
downstream end of bridge. 
Table 1. Bench marks and reference points used in the July 23-26, 2010, Little Maquoketa River, North Fork Little Maquoketa River, Maquoketa River, and North Fork Maquoketa River flood profiles.-Continued

[Bench marks and reference points are listed in upstream order. BM, bench mark; TBM, temporary bench mark; RP, reference point; GPS, Global Positioning System; USGS, U.S. Geological Survey; T, township; R, range; N, north; W, west; S, south; E, east; RM, reference mark; a number in parentheses following the quarter-section designation indicates the sequence number of the BM, TBM, or RP in that particular quarter section]

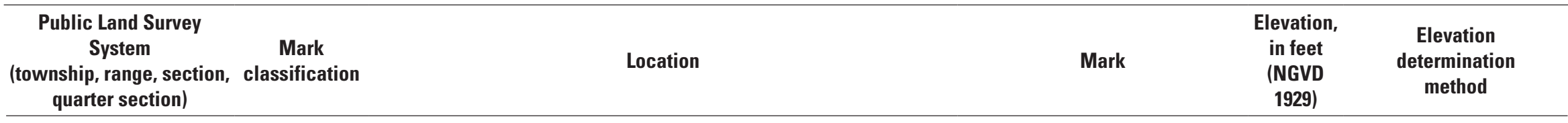

North Fork Maquoketa River

T84N R02E 13 NE (1)

T84N R02E 13 NE (2)

$\mathrm{BM}$

About 1 mile north of Maquoketa, on Rockdale Road

About 1 mile north of Maquoketa, on Rockdale Road bridge over North Fork Three filed marks

Maquoketa River, on guardrail about 3 inches right of 28th guardrail post from left downstream end of bridge.

T85N R02E 25 NE (1)

$\mathrm{BM}$

About 0.5 mile south of Fulton, site of discontinued streamgage 05418450 North Fork Maquoketa River at Fulton, on southbound lane of U.S. Highway 61 bridge over North Fork Maquoketa River (upstream bridge), on left downstream wingwall.

T85N R02E 25 NE (2)

T85N R02E 25 NE (3)

About 0.5 mile south of Fulton, site of discontinued streamgage 05418450 North Fork Maquoketa River at Fulton, on northbound lane of U.S. Highway 61 bridge over North Fork Maquoketa River (downstream bridge), on right downstream wingwall.

About 0.5 mile south of Fulton, site of discontinued streamgage 05418450 North Fork Maquoketa River at Fulton, on northbound lane of U.S. Highway 61 bridge over North Fork Maquoketa River (downstream bridge), on concrete platform behind 4th drain from right downstream end of bridge.

T85N R02E 16 SE (1)

About 2.75 miles northwest of Fulton, site of streamgage 05418400 North Fork Maquoketa River near Fulton, on County Road E17/150th Street bridge over North Fork Maquoketa River, on left downstream wingwall.

T85N R02E 16 SE (2)

About 2.75 miles northwest of Fulton, site of streamgage 05418400 North Fork Maquoketa River near Fulton, on County Road E17/150th Street bridge over North Fork Maquoketa River, on right upstream wingwall.

T85N R01E 10 SW (1)

T85N R01E 10 SW (2)

T85N R01E 05 SW (1)

T85N R01E 05 SW (2)
TBM

About 3.25 miles northeast of Canton, on 60th Avenue bridge over North Fork Maquoketa River, on right upstream bolt on right upstream pier.

About 3.25 miles northeast of Canton, on 60th Avenue bridge over North Fork Maquoketa River, on guardrail about 10 feet left of 2 nd vertical truss member from right downstream end of bridge.

About 2.5 miles northeast of Canton, on 21st Avenue bridge over North Fork Chiseled square Maquoketa River, on roadside end of concrete curb next to metal bracket

Filed cross at left downstream end of bridge.

About 2.5 miles northeast of Canton, on 21st Avenue bridge over North Fork Three filed marks Maquoketa River, on metal guardrail at 4th drain from right downstream end of bridge. lowa Department of Transportation bench mark

lowa Department of Transportation bench mark

Chiseled square

Chiseled square (RM 1)

Chiseled square (RM 3)

$736.15 \quad$ GPS

758.63 GPS

767.33 GPS 
Table 1. Bench marks and reference points used in the July 23-26, 2010, Little Maquoketa River, North Fork Little Maquoketa River, Maquoketa River, and North Fork Maquoketa River flood profiles.-Continued

[Bench marks and reference points are listed in upstream order. BM, bench mark; TBM, temporary bench mark; RP, reference point; GPS, Global Positioning System; USGS, U.S. Geological Survey; T, township; R, range; N, north; W, west; S, south; E, east; RM, reference mark; a number in parentheses following the quarter-section designation indicates the sequence number of the BM, TBM, or RP in that particular quarter section]

\begin{tabular}{|c|c|c|c|c|c|}
\hline $\begin{array}{l}\text { Public Land Survey } \\
\text { System } \\
\text { (township, range, section, } \\
\text { quarter section) }\end{array}$ & $\begin{array}{l}\text { Mark } \\
\text { classification }\end{array}$ & Location & Mark & $\begin{array}{l}\text { Elevation, } \\
\text { in feet } \\
\text { (NGVD } \\
\text { 1929) }\end{array}$ & $\begin{array}{l}\text { Elevation } \\
\text { determination } \\
\text { method }\end{array}$ \\
\hline \multicolumn{6}{|c|}{ North Fork Maquoketa River-Continued } \\
\hline T87N R01W 31 SW (1) & $\mathrm{BM}$ & $\begin{array}{l}\text { At Cascade, on 1st Avenue West bridge over North Fork Maquoketa River, } \\
\text { on corner of right downstream wingwall. }\end{array}$ & $\begin{array}{l}\text { Iowa Department of Transportation } \\
\text { bench mark }\end{array}$ & 828.54 & $\begin{array}{l}\text { Elevation supplied by Iowa } \\
\text { Department of Transpor- } \\
\text { tation }\end{array}$ \\
\hline T87N R01W 31 SW (2) & $\mathrm{RP}$ & $\begin{array}{l}\text { At Cascade, on 1st Avenue West bridge over North Fork Maquoketa River, } \\
\text { on downstream side of cyclone fence centered between 8th and 9th fence } \\
\text { posts from right downstream end of bridge. }\end{array}$ & Edge of concrete sidewalk & 825.52 & $\begin{array}{l}\text { Elevation surveyed from } \\
\text { Iowa Department of } \\
\text { Transportation bench } \\
\text { mark }\end{array}$ \\
\hline T87N R01W 31 SW (3) & $\mathrm{RP}$ & $\begin{array}{l}\text { At Cascade, on 1st Avenue West bridge over North Fork Maquoketa River, } \\
\text { on upstream side of cyclone fence centered between 8th and 9th fence } \\
\text { posts from right upstream end of bridge. }\end{array}$ & Edge of concrete sidewalk & 825.53 & $\begin{array}{l}\text { Elevation surveyed from } \\
\text { Iowa Department of } \\
\text { Transportation bench } \\
\text { mark }\end{array}$ \\
\hline T87N R02W 36 NE (1) & $\mathrm{BM}$ & $\begin{array}{l}\text { About } 0.4 \text { mile north of Cascade, on east bound lane of U.S. Highway } 151 \\
\text { bridge over North Fork Maquoketa River (downstream bridge), on con- } \\
\text { crete rail at left downstream end of bridge. }\end{array}$ & $\begin{array}{l}\text { Iowa Department of Transportation } \\
\text { bench mark }\end{array}$ & 835.61 & GPS \\
\hline T87N R02W 36 NE (2) & TBM & $\begin{array}{l}\text { About } 0.4 \text { mile north of Cascade, on east bound lane of U.S. Highway } 151 \\
\text { bridge over North Fork Maquoketa River (downstream bridge), on con- } \\
\text { crete rail at right downstream end of bridge. }\end{array}$ & Chiseled square & 850.31 & GPS \\
\hline T87N R02W 36 NE (3) & $\mathrm{RP}$ & $\begin{array}{l}\text { About } 0.4 \text { mile north of Cascade, on east bound lane of U.S. Highway } 151 \\
\text { bridge over North Fork Maquoketa River (downstream bridge), on down- } \\
\text { stream concrete rail between } 8 \text { th and } 9 \text { th drains from right end of bridge. }\end{array}$ & Chiseled arrow & 843.28 & GPS \\
\hline T87N R02W 26 NW (1) & $\mathrm{BM}$ & $\begin{array}{l}\text { About } 2 \text { miles northwest of Cascade, on State Highway } 136 \text { bridge over } \\
\text { North Fork Maquoketa River, on left downstream wingwall. }\end{array}$ & $\begin{array}{l}\text { Iowa Department of Transportation } \\
\text { bench mark }\end{array}$ & 843.72 & GPS \\
\hline T87N R02W 26 NW (2) & $\mathrm{BM}$ & $\begin{array}{l}\text { About } 2 \text { miles northwest of Cascade, on State Highway } 136 \text { bridge over } \\
\text { North Fork Maquoketa River, on right downstream wingwall. }\end{array}$ & $\begin{array}{l}\text { Iowa Department of Transportation } \\
\text { bench mark }\end{array}$ & 843.64 & GPS \\
\hline T87N R02W 26 NW (3) & $\mathrm{RP}$ & $\begin{array}{l}\text { About } 2 \text { miles northwest of Cascade, on State Highway } 136 \text { bridge over } \\
\text { North Fork Maquoketa River, on concrete platform behind downstream } \\
\text { concrete barrier wall across from 4th drain from either upstream end of } \\
\text { bridge. }\end{array}$ & Chiseled square & 841.75 & GPS \\
\hline T87N R02W 18 SW (1) & TBM & $\begin{array}{l}\text { About } 3.5 \text { miles south of Worthington, on } 305 \text { th Street bridge over unnamed } \\
\text { tributary to North Fork Maquoketa River, in post near right downstream } \\
\text { wingwall of small wooden bridge. }\end{array}$ & Top of horizontal lag bolt & 864.43 & GPS \\
\hline T88N R03W 36 NE (1) & $\mathrm{BM}$ & $\begin{array}{l}\text { About } 0.5 \text { mile west of Worthington, on County Road D35/272nd Street } \\
\text { bridge over North Fork Maquoketa River, on left upstream wingwall. }\end{array}$ & Delaware County bench mark & 904.62 & GPS \\
\hline
\end{tabular}
bridge over North Fork Maquoketa River, on left upstream wingwall. 
Table 1. Bench marks and reference points used in the July 23-26, 2010, Little Maquoketa River, North Fork Little Maquoketa River, Maquoketa River, and North Fork Maquoketa River flood profiles.-Continued

[Bench marks and reference points are listed in upstream order. BM, bench mark; TBM, temporary bench mark; RP, reference point; GPS, Global Positioning System; USGS, U.S. Geological Survey; T, township; R, range; N, north; W, west; S, south; E, east; RM, reference mark; a number in parentheses following the quarter-section designation indicates the sequence number of the BM, TBM, or RP in that particular quarter section]

\begin{tabular}{|c|c|c|c|c|c|}
\hline $\begin{array}{l}\text { Public Land Survey } \\
\text { System } \\
\text { (township, range, section, } \\
\text { quarter section) }\end{array}$ & $\begin{array}{l}\text { Mark } \\
\text { classification }\end{array}$ & Location & Mark & $\begin{array}{l}\text { Elevation, } \\
\text { in feet } \\
\text { (NGVD } \\
\text { 1929) }\end{array}$ & $\begin{array}{l}\text { Elevation } \\
\text { determination } \\
\text { method }\end{array}$ \\
\hline \multicolumn{6}{|c|}{ North Fork Maquoketa River-Continued } \\
\hline T88N R03W 36 NE (2) & $\mathrm{RP}$ & $\begin{array}{l}\text { About } 0.5 \text { mile west of Worthington, on County Road D35/272nd Street } \\
\text { bridge over North Fork Maquoketa River, on concrete barrier wall be- } \\
\text { tween 13th and 14th concrete posts from left downstream end of bridge. }\end{array}$ & Chiseled square & 904.32 & GPS \\
\hline T88N R02W 06 NW (1) & $\mathrm{BM}$ & $\begin{array}{l}\text { At Dyersville, on eastbound lane of U.S. Highway } 20 \text { bridge over North Fork } \\
\text { Maquoketa River (downstream bridge), on left upstream end of concrete } \\
\text { barrier wall. }\end{array}$ & $\begin{array}{l}\text { Iowa Department of Transportation } \\
\text { bench mark }\end{array}$ & 959.79 & $\begin{array}{l}\text { Elevation supplied by Iowa } \\
\text { Department of Transpor- } \\
\text { tation }\end{array}$ \\
\hline T88N R02W 06 NW (2) & TBM & $\begin{array}{l}\text { At Dyersville, on eastbound lane of U.S. Highway } 20 \text { bridge over North Fork } \\
\text { Maquoketa River (downstream bridge), on right upstream end of concrete } \\
\text { barrier wall. }\end{array}$ & Chiseled cross & 961.81 & $\begin{array}{l}\text { Elevation supplied by Iowa } \\
\text { Department of Transpor- } \\
\text { tation }\end{array}$ \\
\hline T88N R02W 06 NW (3) & $\mathrm{RP}$ & $\begin{array}{l}\text { At Dyersville, on eastbound lane of U.S. Highway } 20 \text { bridge over North Fork } \\
\text { Maquoketa River (downstream bridge), on concrete barrier wall at 9th } \\
\text { drain from left downstream end of bridge. }\end{array}$ & Chiseled square & 960.67 & $\begin{array}{l}\text { Elevation surveyed from } \\
\text { Iowa Department of } \\
\text { Transportation bench } \\
\text { mark }\end{array}$ \\
\hline T89N R02W 05 SW (1) & $\mathrm{BM}$ & $\begin{array}{l}\text { At New Vienna, on State Highway 136/Columbus Street bridge over North } \\
\text { Fork Maquoketa River, on left upstream end of concrete barrier wall. }\end{array}$ & $\begin{array}{l}\text { Iowa Department of Transportation } \\
\text { bench mark }\end{array}$ & $1,005.28$ & $\begin{array}{l}\text { Elevation supplied by Iowa } \\
\text { Department of Transpor- } \\
\text { tation }\end{array}$ \\
\hline T89N R02W 05 SW (2) & $\mathrm{BM}$ & $\begin{array}{l}\text { At New Vienna, on State Highway 136/Columbus Street bridge over North } \\
\text { Fork Maquoketa River, on right downstream end of concrete barrier wall. }\end{array}$ & $\begin{array}{l}\text { Iowa Department of Transportation } \\
\text { bench mark }\end{array}$ & $1,003.01$ & $\begin{array}{l}\text { Elevation surveyed from } \\
\text { Iowa Department of } \\
\text { Transportation bench } \\
\text { mark }\end{array}$ \\
\hline T89N R02W 05 SW (3) & $\mathrm{RP}$ & $\begin{array}{l}\text { At New Vienna, on State Highway 136/Columbus Street bridge over North } \\
\text { Fork Maquoketa River, on concrete barrier wall between 2nd and 3rd } \\
\text { drains from either downstream end of bridge. }\end{array}$ & Chiseled square & $1,004.25$ & $\begin{array}{l}\text { Elevation surveyed from } \\
\text { Iowa Department of } \\
\text { Transportation bench } \\
\text { mark }\end{array}$ \\
\hline T90N R02W 23 NE (1) & $\mathrm{BM}$ & $\begin{array}{l}\text { About } 1.5 \text { miles east of Luxemburg, on U.S. Highway } 52 \text { bridge over North } \\
\text { Fork Maquoketa River, on right downstream concrete rail. }\end{array}$ & $\begin{array}{l}\text { Iowa Department of Transportation } \\
\text { bench mark }\end{array}$ & $1,067.30$ & GPS \\
\hline T90N R02W 23 NE (2) & $\mathrm{RP}$ & $\begin{array}{l}\text { About } 1.5 \text { miles east of Luxemburg, on U.S. Highway } 52 \text { bridge over North } \\
\text { Fork Maquoketa River, on downstream concrete lip at middle of bridge. }\end{array}$ & Chiseled arrow & $1,065.24$ & GPS \\
\hline
\end{tabular}


Publishing support provided by: Rolla Publishing Service Center

For more information concerning this publication, contact: Director, USGS Iowa Water Science Center

P.O. Box 1230

lowa City, IA 52244

(319) 337-4191

Or visit the lowa Water Science Center Web site at: http://ia.water.usgs.gov 

